\title{
REGISTRAR LA MUERTE (1381-1512). UN ANÁLISIS DE TESTAMENTOS Y MANDAS PÍAS CONTENIDOS EN LOS PROTOCOLOS NOTARIALES NAVARROS*
}

\author{
por \\ JULIA BALDÓ ALCOZ \\ ÁNGELES GARCÍA DE LA BORBOLLA \\ Julia Pavón Benito \\ Universidad de Navarra
}

RESUMEN: Los testamentos conservados en el fondo de Notariales de Navarra(AGN y AMT) antes de 1512 son el vebículo que nos permite una aproximación científica a una de las cuestiones más vitales del bombre medieval: su muerte. El análisis de estas fuentes documentales revela una serie de numerosos aspectos que podrian englobarse en lo que denominamos su «universo mental y espiritual». Las actitudes, los gestos, las prácticas religiosas y devocionales se sustentan sobre una base común: la muerte es el inicio de una nueva vida. De este modo, el bombre consciente de su condición de criatura, articula toda una serie de disposiciones testamentarias, de carácter mediador, para conseguir la preciada salvación eterna.

Palabras Clave: Edad Media. Muerte Medieval. Reino de Navarra.

ABSTRACT: The wills preserved in the Archivos de Protocolos Notariales de Navarra (AGN and $A M T$ ) from before 1512 allow a scientific approach to one of the more important questions of medieval life: death. The analysis of these documents reveals some aspects of the mental and spiritual universe of medieval men and women. Attitudes, gestures, religious and devotional practices are built on a common idea: that death is the beginning of a new life. In this sense, the person who knows of his

* Este trabajo se enmarca dentro del Proyecto de Investigación «La muerte en la Navarra Medieval» (1998-2003), financiado por la Universidad de Navarra, Ministerio de Ciencia y Tecnología (PB 1998-0220), Gobierno de Navarra (Resolución 96/2000, de 15 de diciembre) y la fundación privada The Friendly Hand. Julia Baldó Alcoz disfrutó de una beca de la Fundación Caja Madrid durante el año 2000 para la realización de este proyecto.

Hispania, LXV/1, núm. 219 (2005) 155-226 


\section{status as a creature of God articulates the arrangements necessary for obtaining} eternal salvation.

KEY WORDS: Middle Ages. Death. Kingdom of Navarre.

A través del testamento es posible conocer e interpretar los anhelos espirituales del hombre medieval. Se puede afirmar que la tradición historiográfica francesa, de la mano de-grandes maestros como Michel Vovelle o Philippe Ariès, ha influido en el surgimiento de una corriente científica de investigación que apuesta por el testamento como centro y objeto de estudio para acercarnos a uno de los más sugerentes aspectos de la vida en el medievo: las actitudes y manifestaciones externas ante la muerte.

Con esta finalidad, se ha elegido el conjunto de testamentos conservados en los Archivos de Protocolos Notariales del reino de Navarra antes de 1512 (AGN y AMT). Si bien una buena parte de ellos datan del siglo XV, los anteriores, procedentes de la ciudad de Tudela (siglo XIV), son de lo más elocuente. Se ha de tener en cuenta que esta clase de documentos no ha sido objeto de ningún tipo de análisis exhaustivo como material de trabajo para adentrarse en el universo mental de este espacio soberano ${ }^{1}$. Podrían haberse utilizado más testimonios, por ejemplo otros testamentos procedentes de archivos parroquiales o nobiliarios y legislación, que se conocen. Pero con este artículo se quiere establecer un punto de partida que presente unos primeros resultados, previos a ofrecer una gran síntesis de la muerte en la Navarra medieval.

Por eso, y sin tratar de elevar las conclusiones a un rango genérico, se ha querido describir e interpretar la dimensión de las últimas voluntades: bajo qué circunstancias y por qué se redacta el testamento, qué anhelos espirituales motivan al hombre para disponer su memoria funeraria y mandas pías, y cómo, en último lugar, la comunidad acoge, vela, acompaña y recuerda al difunto.

\section{UN BREVE REPASO HISTORIOGRÁFICO}

No cabe duda de que la historiografía francesa ha concebido y liderado, fruto de las líneas de trabajo abiertas desde la Escuela y tradición de Annales, la lla-

1 Béatrice LEROY es la única investigadora que ha trabajado con documentación de protocolos notariales medievales, concretamente, con los pertenecientes a la ciudad de Tudela. Véanse, entre otras publicaciones: "Vie et mort à Tudela en 1380-1383: Le testament de Bernarda de Pimbo" en Annales de la Faculté des Lettres et Sciences Humaines de Nice (París) 46 (1983), pp. 141-153. «La mort et la vie chretienne en Navarre au XIVe siècle. (Étude de testaments de la seconde moitié du XIVe siècle)» en De la Iglesia y de Navarra. Estudios en honor del Prof. Goñi Gaztambide (Pamplona) (1984), pp. 245-257. «Tudela en 1381-83 à travers le registre du notaire Martin Don Costal» en Príncipe de Viana (Pamplona) 47179 (1986), pp. 723-739. O «Tudela au XIIIème siècle, à la lumière de ses archives locales» en Príncipe de Viana (Pamplona) 58212 (1997), pp. 557-565.

Hispania, LXV/1, núm. 219 (2005) 155-226 
mada «historia de las mentalidades», dentro de un amplio campo de la nueva historia cultural en la década de los setenta y ochenta del siglo $\mathrm{XX}^{2}$.

En ese contexto y con la intención de reconstruir el universo mental del hombre histórico, concretamente durante el medievo y las centurias modernas, surgió la «historia de la muerte» con trabajos pioneros en su época y hoy referentes clásicos. Son las obras de Michel Vovelle 3 , Philippe Ariès 4 , M. T. Lorcin ${ }^{5}$, Pierre Chaunu ${ }^{6}$, Emmanuel Le Roy Ladurie ${ }^{7}$, Edgar Morín ${ }^{8}$ y algunos otros; precedidas en el tiempo por las reflexiones de Jacques Choron'. Y las líneas maestras que en el campo de la historia del arte abrió Alain Erlande-Brandenburg con Le roi est mort ${ }^{10}$, entroncado, en cierta medida con el clásico El otoño de la Edad Media de Johan Huizinga ${ }^{11}$, las reflexiones de Alberto Tenenti en La vie et la mort à travers l'art $d u X V^{c}$ siècle ${ }^{12}$, y los novedosos planteamientos de Ernst Kantorowicz publicados en 1957, traducidos muy tardíamente en 1985 con el título Los dos cuerpos del rey. Un estudio de teología política moderna.

Esta nueva forma de reflexionar sobre la «historia», así como la aportación de un determinado método de investigación en estrecha relación con la «larga duración» fueron decisivos en la creación de un «modelo», una «escuela». Buena prueba de ello es la consolidación de esta nueva corriente en los años ochenta con obras tan determinantes como La comptabilité de l'au-delà. Les hommes, la mort et la religion dans la région d'Avignon à la fin du Moyen Âge (vers 1320-vers 1480) de Jacques Chiffoleau ${ }^{13}$. Trabajo señero para los análisis regionales que fueron suscitándose no sólo en Francia, sino también en el resto de la Europa Occidental.

2 AURell, Jaume: «Introducción. La transversalidad de la historia de la muerte en la Edad Media» en Aurell, Jaume y PAvón, Julia (eds.): Ante la muerte. Actitudes, espacios y formas en la España medieval, Pamplona (2002), pp. 9-26.

3 Aunque es copiosa la aportación de Michel Vovelle baste destacar Mourir autrefois. Attitudes collectives devant la mort aux XVII' et XVIII' siècles, París, 1974 y La mort et l'Occident de 1300 à nos jours, París, 1983.

${ }^{4}$ Trabajos como Essais sur l'bistoire de la mort en Occident du Moyen Âge á nous jours, París, 1975, La mort au coeur de la vie, Colmar, 1976 y L'bomme devant la mort, París, 1977.

5 LORCIN, Marie-Thérèse: «Les clauses religieuses dans les testaments lyonnais aux XIV-XV siècles», Le Moyen Âge (París) 78 (1972), pp. 267-287.

6 CHAunu, Pierre: «Mourir à Paris (XVI ${ }^{\mathrm{e}}-\mathrm{XVII}^{\mathrm{e}}$-XVIII ${ }^{\mathrm{e}}$ siècles)», Annales E.S.C. (París) 311 (1976) 29-50 y La mort à Paris, París, 1978.

7 L'Argent, L'Amour et la Mort en Pays d'Oc, París, 1980

${ }^{8} L$ 'bomme et la mort devant l'Histoire, París, 1976.

9 CHoron, Jacques: Death and Modern Man, Nueva York, 1964 y La Mort dans la pensée occidentale, París, 1969.

10 ERLANDE-Brandenburg, Alain: Le roi est mort. Étude sur les funérailles, les sépultures et les tombeaux des rois de France jusqu'á la fin du XIII siècle, Ginebra, 1975.

${ }^{11}$ El otoño de la Edad Media. Estudios sobre las formas de vida y el espiritu durante los siglos XIV y $X V$ en Francia y en los Países Bajos, Buenos Aires, 1947.

12 Publicado en París en 1952.

13 Publicada en Roma el año 1980. 


\subsection{Aportaciones peninsulares}

Hasta recoger la influencia de los «padres de la muerte», en la Península Ibérica se estudiaron aspectos concretos de este mundo ligados al ámbito jurídico, teológico y literario. Se remonta a los años treinta, cuarenta y cincuenta la aparición de investigaciones de corte histórico-jurídico sobre las herencias y aspectos funerarios firmados por Luis García de Valdeavellano ${ }^{14}$, José Maldonado y Fernández del Torco ${ }^{15}$, José Orlandis ${ }^{16}$, Matías Martínez Pereda ${ }^{17}$ o Alfonso García Gallo ${ }^{18}$.

Las consecuencias del conflicto civil español mermaron la investigación en el ámbito académico durante un largo período de tiempo ${ }^{19}$ y hubo que esperar a los años 80 para que la influencia historiográfica del país vecino calara en el nuestro. En un primer momento se acogieron e «imitaron» las obras francesas a través de memorias de licenciatura y otros trabajos pioneros realizados en la Universidad de Extremadura y Madrid ${ }^{20}$.

Pero poco más tarde la admiración y la imitación de la comunidad científica se comenzaron a encauzar, fruto de una reflexión pausada, hacia unos objetivos más propios ${ }^{21}$. Baste recordar la trascendencia del II Coloquio de Metodología Histórica que tuvo lugar en Santiago de Compostela en 1982. Allí, un nutrido grupo de historiadores y especialistas peninsulares mostraron, con sus reflexiones, la aplicación práctica y los nuevos campos de investigación que abría, entre otros, la herencia historiográfica francesa ${ }^{22}$.

14 «La cuota de libre disposición en el Derecho hereditario de León y Castilla en la Alta Edad Media» en Anuario de Historia del Derecho Español (Madrid) 9 (1932), pp. 129-176.

15 Herencias a favor del alma en el Derecho español, Madrid, 1944.

16 «Sobre la elección de sepultura en la España medieval» en Anuario de Historia del Derecho Español (Madrid) 20 (1950), pp. 5-49.

17 "Reflexiones jurídicas sobre la llamada sucesión a favor del alma» en Anales de la Academia matritense del notariado (Madrid) 7 (1953), pp. 145-156.

18 «Del testamento romano al medieval. Las líneas de su evolución en España» en Anuario de Historia del Derecho Español (Madrid) 47 (1977), pp. 425-498.

19 MITRE, Emilio: «La historiografía sobre la Edad Media» en ANDRÉs-GALLEGO, José (coord.), BlázQuez, José $\mathrm{M}^{\mathrm{a}}$, Mitre, Emilio, SÁNChez MARcos Fernando y Cuenca Torubio; José $\mathbf{M}^{2}$ : Historia de la Historiografía española (Madrid) 2000, pp. 95-96.

${ }^{20}$ A modo de muestra las memorias de licenciatura inéditas de VALVERDE, R. M.: La muerte en cuatro núcleos rurales cacereños durante el siglo XVII, 1979, Universidad de Extremadura y DIÉGUEZ DELGADO, A. D.: Religión y sociedad en la segunda mitad del siglo XVII según los protocolos notariales de Antonio Bravo: Madrid, 1664-1676, 1980, Universidad Complutense de Madrid. También los trabajos de RoḌíGUEZ SÁNCHEZ, Ángel: «Morir en Extremadura. Una primera aproximación» en Norba (Cáceres) 1 (1980), pp. 279-297 y Morir en Extremadura (La muerte en la borca a finales del Antiguo Régimen, 1792-1909), Cáceres, 1980.

${ }^{21}$ EGIDO LÓPEZ, Teófanes: «La nueva historia de la muerte» en Revista de espiritualidad (San Sebastián) 40 (1981), pp. 43-65.

22 EIRAS Roel, Antonio (ed.): Il Coloquio de Metodología histórica aplicada: la documentación notarial y la Historia, Santiago de Compostela, 1982.

Hispania, LXV/1, núm. 219 (2005) 155-226 
Aquel mismo año de 1982 Emilio Mitre publicaba Historiografía y mentalidades históricas en la Europa Medieval, primer paso de un largo y copioso camino que le adentraría en la llamada «historia de la muerte». Ante las crecientes aportaciones dentro de esta temática, ligadas a aspectos concretos de la religiosidad, espiritualidad, actitudes y costumbres funerarias, rituales, y por supuesto series testamentarias, el profesor Mitre elevaría su singular aportación y pautado teórico. Así, son de obligada referencia títulos de la categoría de La muerte vencida. Imágenes e bistoria en el Occidente medieval (1200-1348) ${ }^{23}$, o La muerte y sus discursos dominantes entre los siglos XIII y XV24; trabajo que encabezó el congreso «Muerte, religiosidad y cultura popular. Siglos XIII-XVIII» organizado por la Institución Fernando el Católico de Zaragoza en diciembre de 1990.

La celebración de este foro de ideas y debate vino a reflejar las nuevas inquietudes y necesidades de los investigadores hispanos, deseosos no sólo de asumir la tradición europea sino de comunicar los resultados de un nuevo quehacer en la historia de España. Así puede entenderse, por poner un ejemplo, el interés relativo al ceremonial funerario de diversas cortes y monarquías del Occidente cristiano medieval. De entre los historiadores pioneros que se dedicaron a este tema destacan Nadia Pollinii25, Giesey ${ }^{26}$, Erlande-Brandenburg ${ }^{27}$, así como Kantorowicz ${ }^{28}$. En España los estudios sobre las exequias regias y cortesanas fueron muy posteriores, destacando varios títulos que se centran en las honras fúnebres de la monarquía castellana, de Mitre ${ }^{29}$, Denis Menjot ${ }^{30}$; Nieto Soria ${ }^{31}$ o González Arce ${ }^{32}$;

23 Publicado en 1988

${ }^{24}$ Recogido en SERRANO MARTín, Eliseo: Muerte, religiosidad y cultura popular. Siglos XIIIXVIII, Zaragoza, 1994, pp. 15-34.

25 Pollini, Nadia: La Mort du Prince. Rituels funéraires de la Maison de Savoie (1343-145.1), Lausanne, 1884

${ }^{26}$ GIESEY, Ralph E.: The Royal Funeral Ceremony in Reinassance France, Ginebra, 1960. Le roi ne meurt jamais. Les obsèques royales dans la France de la Reinassance, París, 1987.

${ }_{27}$ Le roi est mort. Étude sur les funérailles, les sépultures et les tombeaux des rois de France jusqu'á la fin du XIIIe siècle, Ginebra, 1975.

${ }^{28}$ KANTOROWICZ, Ernst H.: Los dos cuerpos del rey. Un estudio de teología política medieval, Madrid, 1985.

29 Mitre FerNÁNDEZ, Emilio: «La muerte del rey: La historiorafía hispánica (1200-1348) y la muerte entre las élites» en En la España Medieval (Madrid) 11 (1988), pp. 167-183. «Muerte y memoria del rey en la Castilla bajomedieval» en DUBY, Georges (et al.): La idea y el sentimiento de la muerte en la Historia y en el Arte de la Edad Media (II), Santiago de Compostela, 1992, pp. 17-26. Una muerte para un rey: Enrique III de Castilla (Navidad de 1406), Valladolid, 2001.

30 MENJOT, Denis: «Les funerailles des souverains castillans du bas Moyen Âge racontées par les chroniqueurs: une image de la souveraineté» en Annales de la Faculté des Lettres et Sciences Humaines de Nice. Mélanges Jean Larmat (París) 39, 1982, pp. 195-209. Y «Un chrétien qui meurt toujours. Les funerailles royales en Castille à la fin du Moyen Age» en DuBY, Georges (et al.): La idea y el sentimiento de la muerte en la Historia y en el Arte de la Edad Media (II), Santiago de Compostela, 1992, pp. 127-138.

31 Nieto Soria, José Manuel: Ceremonias de la realeza. Propaganda y legitimación en la Castilla Trastámara, Madrid, 1993.

32 GONZÁLEZ ARCE, José Damián: Apariencia y poder. La legislación suntuaria castellana, en los siglos XIII y XV, Jaén, 1998. 
mientras que otros autores como Laliena e Iranzo ${ }^{33}$ o Flocel Sabatè ${ }^{34}$ han focalizado sus trabajos en el reino aragonés y en el territorio catalán, respectivamente. Finalmente, para el reino navarro, es necesario mencionar los trabajos llevados a cabo por Eloísa Ramírez Vaquero ${ }^{35}$ y Pascual Tamburri ${ }^{36}$.

El congreso de Zaragoza continuaba el camino abierto por el ciclo de conferencias que tuvo lugar en Barcelona (1984) y en Santiago de Compostela entre el 1 y 5 de diciembre de 1986, bajo el título: La idea y sentimiento de la muerte en la bistoria y en el arte de la Edad Media. El éxito de la empresa y la riqueza de sus conclusiones posibilitaron el desarrollo de un segundo encuentro; esta vez entre el 15 y 19 de abril de 1991.

Tanto estas publicaciones como el excelente cauce galo proporcionaban los instrumentos metodológicos y formales para sacar el máximo provecho a un determinado tipo de documento: el testamento. Fue considerado desde entonces como pieza clave para explorar el mundo mental y las actitudes ante la muerte. Son numerosos los trabajos que lo han tomado rigurosamente como fuente primera, o quizá única, para presentar ciertas conclusiones sobre la espiritualidad o religiosidad de un marco espacial concreto. Sin embargo, es posible que la influencia del método "cuantitativo» de la tesis sobre la región de Aviñón haya ensombrecido una visión más amplia de las posibilidades documentales, no sólo del testamento sino de otras fuentes potenciales. En otras palabras, para establecer resultados y conclusiones sobre el universo y formas de espiritualidad medieval, el análisis testamentario es un primer paso, pero no el único.

Para el territorio peninsular existe en la actualidad un elenco bibliográfico, bastante completo, qué analiza los testamentos y demás documentación asociada a Elche (1294-1444), Reus en el XIV, Galicia (siglos IX-XI), la Castilla del XIV, Murcia, Salamanca (siglos XV-XVII), Jaén en el XVIII, Córdoba $\left(2^{\mathrm{a}}\right.$ mitad del XV), Jerez de la Frontera (siglo XV), el Madrid bajomedieval, Zamora (15001800), Valladolid, el Toledo de los Austrias, el Cádiz del setecientos, la Extremadura del XVIII-XIX, la Calatayud del XV, Yecla del XVI, Cáceres en el XVIII, sin olvidarnos de Portugal, tanto en el alto como en el bajo medievo.

El ejercicio descriptivo e interpretativo de tantas aportaciones, a la luz de la clásica bibliografía ultrapirenaica, se ha visto, en estos últimos años, enriquecido por dos obras cuya autoría se deben Fernando Martínez Gil y Ariel Guian-

33 Laliena Corbera, Carlos, Iranzo Muñío, $\mathbf{M}^{a}$ Teresa: «Las exequiais de Alfonso $\mathrm{V}$ en las ciudades aragonesas. Ideología real y rituales públicos» en Aragón en la Edad Media, (Zaragoza) 9 (1991), pp. 55-75.

34 SABATÉ I CURULL, Flocel: Lo senyor rei és mort: actitud $i$ cerimònies dels municipis catalans baixmedievals davant la mort del monarca, Lérida, 1994.

35 «Liturgia de la realeza bajomedieval» en Signos de Identidad Histórica para Navarra, Pamplona, 1996, pp. 387-398.

36 «Un fúneral regio. La rèina Blanca de Navarra» en Signos de Identidad Histórica para Navarra, Pamplona, 1996, pp. 309-404. Y «Los restos de la reina Blanca y sus funerales en Pamplona» en Príncipe de Viana (Pamplona) 57. 208 (1996), pp. 345-357.

Hispania, LXV/1, núm. 219 (2005) 155-226 
ce, respectivamente. Si bien el primero expresaba su ánimo de establecer los precedentes, el antes y el porqué de la idea y vivencias sobre la muerte para la España de los Austrias en La muerte vivida ${ }^{37}$, el segundo presentaba una monografía de mayor calado. Centrado en el territorio de Castilla, el Dr. Guiance, sin recurrir a los lugares comunes y sin lagunas metodológicas, elaboraba una de las grandes síntesis sobre la muerte en la Edad Media peninsular ${ }^{38}$.

La investigación recupera la construcción ideológica sobre la muerte alumbrada desde esferas civiles y clericales a través de la normativa jurídica, cánones conciliares y sinodales, además de los testimonios literarios. Además expone y demuestra que los discursos eruditos no discurrieron al margen o por encima de una supuesta cultura popular con el fin de alentarla o acallarla, sino que ambos ámbitos venían a identificar los dos lados de una misma moneda. Y frente al aluvión del modelo francés realza la singularidad peninsular, ya que la herencia hispanogoda determinó muchas de las prácticas formales de la vida del hombre, y por ende de las formas funerarias. Dicho estudio es, por tanto, ese paso adelante que va desde la necesaria, pero primera cuantificación, hacia una fase interpretativa que descubre los rasgos privativos en un gran marco espacial y en un largo período de tiempo, libre de cualquier atadura historiográfica.

$\mathrm{Y}$, ahora, ¿qué?. La respuesta, sencilla y compleja, encierra una propuesta. Realizar una gran síntesis de la muerte para la España medieval que armonice el mosaico de los esfuerzos de tantos, y no por ello menos meritorios, trabajos locales. Y, lejos de un mero modelo cuantitativo, fijar los objetivos en las singularidades de esta península, atendiendo a la gran riqueza de nuestro legado documental y artístico.

\section{NOTARIOS Y PROTOCOLOS}

Antes de adentrarse en el contenido y dimensión religiosa de los protocolos conviene conocer primeramente las características de la institución notarial y la suerte de los fondos notariales del reino de Navarra, para la Edad Media.

\subsection{La institución del notariado en Navarra}

A grandes rasgos se puede afirmar que el volumen de Protocolos Notariales conservados para antes del siglo XVII en Navarra es cuantioso, variado y enriquecedor. Pero si la valoración del conjunto documental se acota a los siglos XIV y $\mathrm{XV}$, hay que destacar sus significativas lagunas y carencias porque no se puede fechar hasta los albores del XVI el inicio de una serie, más o menos continuada y

${ }^{37}$ La muerte vivida. Muerte y Sociedad en Castilla durante la Baja Edad Media, Toledo, 1996.

${ }^{38}$ Los discursos sobre la muerte en la Castilla medieval (siglos VII-XV), Valladolid, 1998. 
completa de las actas. Sucede lo mismo para el territorio histórico de Castilla, pero no para los espacios integrados en la corona aragonesa ${ }^{39}$, donde la abundancia y relevancia de sus textos se une a una temprana conservación de los mismos ${ }^{40}$.

El primer protocollum navarro conocido procede de la notaría de Martín Garceiz Don Costal, con sede en la ciudad de Tudela. El conjunto de textos, fechado a comienzos del año 1381, forma parte de un libro de unos trescientos folios que abarca hasta el mes de diciembre de 1383. Estos presentan unas características formales y tipológicas excepcionales, amén del buen estado de conservación. Y además llama la atención la variedad de las actuaciones registradas, y la minuciosidad en la redacción, incluso si se compara con otros posteriores. De hecho, se han entresacado un conjunto de 47 documentos, entre testamentos, codicilos, fundaciones de aniversarios y concesiones de sepulturas.

La muestra, de la oficina de los Garceiz, evidencia la práctica y usos de una, llamémosla, institución que aparece más que modelada en el siglo XIV. Sin embargo, no constan datos elocuentes que refieran en qué momento y bajo qué circunstancias se formalizó la actividad notarial, en el sentido actual del término, con su lógica generación de libros y registros.

A tenor de los estudios publicados para este reino, se puede deducir que el cambio que se operó en el ámbito de la expedición documental, sobre la decimotercera centuria, permitió el nacimiento y consolidación del notariado público $^{41}$. Notarios jurados o episcopales se revisten de atribuciones fiduciarias emanadas y compartidas por el poder soberano. Su tarea tiene como finalidad conferir autenticidad legal a las actuaciones que describen y rubrican, surgiendo el llamado instrumentum publicum.

Las regulaciones de vida municipal, la compilación foral navarra y otras fuentes complementarias presentan, para el siglo XIII, el núcleo de una primigenia organización notarial. Como representantes e integrantes de la instituciones a las que prestan sus servicios, estos peritos en el arte de escribir exponen, registran y validan una serie de actuaciones de la esfera privada. Emiten textos que recogen acuerdos, contratos, últimas voluntades y otros asuntos

39 En el cercano reino aragonés, sabemos que la serie protocolaria comienza en 1316 para la ciudad de Zaragoza, y en 1398 para Calatayud. Cfr. BARRAQUÉ, Jean Pierre: Saragosse à la fin du Moyen Âge. Une ville sous influence, París, 1998, p. 14. GARCíA Herrero, $\mathrm{M}^{\mathrm{a}}$ Carmen: «Ritos funerarios y preparación para Bien Morir en Calatayud y su comunidad (1492)» en Revista de Historia Jerónimo Zurita (Zaragoza) 59-60 (1989), p. 90. Y RUBIO SEMPER, Agustín: «Piedad, honras fúnebres y legados piadosos en Aragón (Calatayud) en la Baja Edad Media» en SERrano MarTín, Eliseo (dir.): Muerte, Religiosidad y Cultura popular. Siglos XIII-XVIII, (Zaragoza) 1994, p. 241.

40 Pavón Benito, Julia: «Del scriptor al notarius publicus. Notas acerca de los orígenes de la institución notarial en Navarra (siglos XI-XII)» en $V$ Congreso de Historia de Navarra (Pamplona) 2002, vol. I, p. 136.

41 García Larragueta, Santos: «Auctoritas et Potestas. Territorialidad del notariado en el reino de Navarra» en Notariado público y documento privado: de los origenes al siglo XIV. Actas del VII Congreso Internacional de Diplomática, (Valencia) 1986, vol. I, pp. 201-243. 
entre particulares, otorgándoles de esta manera su carácter fiduciario. El creciente volumen de esta actividad y la necesidad de no entremezclar asuntos con las instituciones elevaría al notario a una nueva categoría funcional.

La dimensión de los actos que avalan estos escriuans, que daban a las escrituras el carácter de público instrumento, acabó por vincular el documento con sus personas y establecimientos, sedes o casas. Se formaban así los depósitos documentales notariales. Pero los variados avatares de estas familias, las diferentes situaciones coyunturales e históricas acontecidas desde el siglo XIV y la indefinición de un criterio uniforme a la hora de conservar sus cartas, notas y protocolos son las causas del panorama actual de conservación de las fuentes notariales.

La redacción tardía del Fuero de Tudela (1330) presentaba la necesidad de dar una solución al tema de los archivos notariales, al regular sobre:

el fecho de los escribanos, que, cuando mueren, los registros fincan en las mulleres ó en lures herederos, ó en lures parientes ó cabezaleros, lo que es contra razon, é dond muitos males end han venido en la villa de Tudela é daqui adelant se end podrian seguecer, ordenamos que, luego que el escribano finará, lalcalde é los jurados, ó algunos dellos con lalcalde, vayan á la casa del escribano é pongan todos los registros é las notas á su mano, é las pongan en su deposito... ${ }^{42}$

El interés por garantizar la conservación y buen uso del notularium se mantiene a lo largo de los siglos XVI al XIX. Un repaso de las leyes de las Cortes y otras disposiciones institucionales reflejan la preocupación por encauzar lo que era ya de estricta necesidad: habilitar un archivo de protocolos, caso de Pamplona, que estaría inicialmente ubicado en la Casa Consistorial ${ }^{43}$.

A pesar de los esfuerzos para ordenar y concentrar todos los fajos de documentación notarial histórica por parte de Teodoro Ochoa (1859), Ramón Yanguas (1879), Juan Miguel Astiz (1917), Juan San Juan Otermin ${ }^{44}$ y más tarde Florencio Idoate Iragui, ha sido imposible evitar la desaparición de un elevado número de legajos. Situación, además, agravada por los sucesivos traslados de los mismos. Los fondos que han llegado hasta nuestros días se custodiaron entre 1974 y 2003 en el depósito pamplonés de la calle Virgen del Puy (merindades de Pamplona, Sangüesa, Estella y Olite) y en el tudelano del palacio del marqués de Huarte (merindad de Tudela). Actualmente los documentos depositados en Pamplona han sido trasladados al AGN.

42 YanguAS, José: Diccionario de Antigüedades del Reino de Navarra, Pamplona, 1964, vol. 3, p. 422.

43 MartinenA, Juan José: Guía del Archivo General de Navarra, Pamplona, 1997, pp. 273-279, relata la trayectoria de los documentos hasta habilitarse su depósito y recoge la legislación pertinente.

${ }_{44}$ Ambos publicaron en las fechas señaladas índices de los fondos de protocolos y Juan SAN JUAN elaboró un índice, publicado en Pamplona, en el año 1942: Índice del Archivo General de Protocolos de Pamplona por la Institución Príncipe de Viana. En él relata las vicisitudes de los documentos hasta entonces. 


\subsection{Tratamiento y valoración de los protocolos. El testamento}

Con la intención de localizar y trabajar con las actas notariales anteriores a 1512, se ha consultado inicialmente el Inventario del Archivo Histórico de Protocolos Notariales de Navarra publicado por Carlos Idoate y Julio Segura en $1985^{45}$. Se observó en primera instancia que el legado medieval estaba concentrado en torno a cinco núcleos: Tudela, Salinas de Oro, Santesteban, Puente la Reina y Elizondo, siendo además escasos los testimonios de los tres últimos. Ninguna aportación, siquiera libro de registros, se ha conservado para localidades tan importantes entonces como Pamplona, Estella, Sangüesa u Olite. Por no citar alguna otra población, con rango menor, pero sin duda con actividad notarial.

La suerte y destino de tan innumerable volumen protocolario ha estado unido a los avatares del tiempo y a la falta de una temprana y eficaz línea de actuación gubernamental, con la finalidad de conservar tan dispersa actividad escrita. Aunque la preocupación ya mereció atención en el fuero de Tudela de 1330 , tenor antes citado.

Pero no por existir tal panorama, los resultados pueden desmerecer. Las búsquedas, acopio y análisis documental entre las cajas de los más de veinte notarios que registran actividad antes de 1512, arrojan un total de 547 protocolos relacionados con la muerte, predominando los testamentos.

Destacan los fondos de la ciudad de Tudela (1381-1512), por su antigüedad, volumen y riqueza. Tampoco se pueden menospreciar las 124 actas extraídas, en su mayoría, del legado de Juan Miguel de Salinas, notario de la villa de Salinas de Oro (1462-1512), y que a primera vista dan la oportunidad de contrastar costumbres y usos funerarios de los espacios rurales del valle de Guesálaz con la próspera urbe tudelana.

El resto de los protocolos, cronológicamente muy dispares, pertenecen a cuatro notarios de Santesteban (1422-1505), con quince testamentos. Y a lo que cabe considerar como meras muestras de las localidades de Elizondo (1509-1512) y Puente la Reina (1491-1512), con tres y seis textos, respectivamente.

En el ya conocido artículo de Michel Vovelle sobre la génesis y carácter del aprovechamiento de las fuentes notariales por parte de la ciencia histórica ${ }^{46}$, se afirma que su utilización va intrínsecamente unida a la historia de la cultura y las mentalidades. Sobre todo, desde que en la década de los años sesenta los investigadores "descubren» la dimensión espiritual de los testamentos. Y además, en otro orden de cosas, que para plantear y proponer conclusiones de carácter general, el historiador no debe de olvidar que su tarea ha de tomar como punto de partida la seriación documental.

\footnotetext{
${ }^{45}$ Cfr. Idoate, Carlos y Segura, Julio: Inventario del Archivo Histórico de Protocolos Notariales de Navarra, Pamplona, 1985.

46 Vovelle, Michel: «Minutes notariales et Histoire des cultures et des mentalités» en Actas del II Coloquio de Metodología Histórica Aplicada. La documentación notarial y la Historia, Santiago de Compostela, 1986, vol. 2, pp. 9-26.
}

Hispania, LXV/1, núm. 219 (2005) 155-226 


\begin{tabular}{|c|c|c|c|c|c|c|c|c|c|}
\hline \multirow{2}{*}{ NOTARÍA } & \multirow{2}{*}{ AÑos } & \multirow{2}{*}{$\begin{array}{c}\text { TEXTOS } \\
\text { REVISADOS }\end{array}$} & \multicolumn{7}{|c|}{ TIPOLOGÍA DOCUMENTAL } \\
\hline & & & Testamentos & ABONIMIENTOS & Codicilos & $\begin{array}{l}\text { FUNDACIÓN } \\
\text { CAPELLANÍAS }\end{array}$ & $\begin{array}{l}\text { FUNDACIÓN } \\
\text { ANIVERSARIOS }\end{array}$ & $\begin{array}{l}\text { CONCESIÓN } \\
\text { SEPULTURAS }\end{array}$ & OTROS \\
\hline Elizondo & $1509-1512$ & 3 & $\begin{array}{c}3 \\
2 \\
1+\text { abonimiento }\end{array}$ & - & - & - & - & - & - \\
\hline $\begin{array}{l}\text { Puente } \\
\text { la Reina }\end{array}$ & $1491-1512$ & 6 & 6 & - & - & - & - & - & - \\
\hline $\begin{array}{l}\text { Salinas } \\
\text { de Oro }\end{array}$ & $1462-1512$ & 124 & $\begin{array}{c}115 \\
90 \\
\text { 10+abonimientos } \\
\text { 11+borradores } \\
\text { 4+codicilos }\end{array}$ & 2 & 4 & - & - & 1 & 2 \\
\hline Santesteban & $1422-1505$ & 15 & 15 & - & - & - & - & - & - \\
\hline Tudela & $1381-1512$ & 399 & $\begin{array}{c}318 \\
313 \\
\text { 2+abonimientos } \\
\text { 3+codicilos } \\
\end{array}$ & 1 & 13 & 5 & 37 & 17 & 8 \\
\hline TOTAL & $1381-1512$ & 547 & 457 & 3 & 17 & 5 & 37 & 18 & 10 \\
\hline
\end{tabular}


Esa prospección cuantitativa masiva, ya sea de ámbitos locales o regionales, ha de tener la finalidad de proyectar un modelo, pero de carácter diferencial. No existe un «modelo» para la «historia de la muerte» en sí, a pesar de las ejemplares obras de algunos autores ya citados, o incluso del recién aludido Vovelle. Cada aportación ha de contener una serie de indicadores y singularidades, pero no un cerrado grupo de elementos. Así y para la historia peninsular, en la medida que se vayan culminando diferentes síntesis locales y regionales se podrá crear «una geografía diferencial de actitudes colectivas ${ }^{47}$ ».

Una primera exposición y descripción cuantitativa de los documentos navarros es incapaz de desvelar con toda claridad la riqueza y expresividad de sus contenidos. Incluso si, yendo un poco más allá, se recuerda el encorsetamiento de los mismos entre fórmulas repetitivas. Recetarios que siguen ocultando y/o dificultando una lectura cultural y mental de las inquietudes más íntimas del hombre medieval. Pero, tal y como señala Vovelle, el testador no es un actor pasivo ante los estereotipos redactados en el testamento ${ }^{48}$, que, por otro lado, también evolucionan y cambian al calor de nuevos tiempos. Sino que a través de cada uno de los protocolos, y en una secuencia de encadenamiento cronológico y temático se pueden obtener resultados óptimos.

Al mostrar una primera cuantificación de los documentos, se quiere dejar claro que se presenta el material y sustento instrumental del estudio. Es decir, que a pesar de la existencia de una tabla de clasificación, no se pretende glosar y describir únicamente esos "estereotipos», tarea por el contrario más cómoda y quizá más superficial. Se considera, por el contrario, que trabajando los protocolos en un marco mayor, se pueden apreciar unos contenidos de gran fecundidad espiritual y religiosa en relación con las esperanzas, actitudes y disposiciones del hombre ante la muerte. Y también de la asimilación y proyección personal de los modelos culturales de una época.

\section{El TESTADOR. DIMENSIÓN ESPIRITUAL Y RELIGIOSA DE LAS ÚlTIMAS VO- LUNTADES}

A primera vista, la lectura crítica de poco más de varias docenas de testamentos de finales del siglo XIV, del XV y comienzos del XVI, permite afirmar que la estructura de un texto de este tipo aparece claramente bipolarizada. Encabeza el protocolo un corpus de carácter espiritual, más o menos extenso, en el que el declarante reflexiona sobre la transcendencia y significación de la vida humana al calor de la Revelación. Es el hombre, entonces, la criatura de Dios elevada al orden sobrenatural por la Gracia, fuente de la verdadera Vida. Aspiración de todas las almas cristianas que han recurrido y recurren en la hora de la muerte a Jesucristo, su Madre santísima, la Corte Celestial y los Santos.

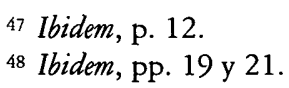


Fruto de ese anhelo surgen espontáneamente los compromisos religiosos del testador que no duda en dispensar con la mayor generosidad posible, todos aquellos beneficios para la memoria y refrigerio de su alma.

Tras este hilado y bien trabado conjunto de disquisiciones espirituales, se especifican en una nítida segunda parte las disposiciones de orden material, para que, al prefigurar el reparto del patrimonio y bienes temporales, se asegure una pacífica transmisión hereditaria. Y de esta manera desaparezcan o se reduzcan las más que posibles reyertas y discordias familiares.

No obstante, para esta ocasión, el estudio se va a detener en esa primera parte del testamento, fuente de conocimiento de la dimensión religiosa y espiritual del hombre medieval, pero no única. La expresividad del testamento se reduce a recoger últimas voluntades, reflexiones finales que enmarcan las creencias más íntimas de un sujeto que se sabe cercano al momento de rendir cuentas con su Hacedor. Para ello se vale de un perito en la materia que le orienta y asesora en la redacción formal de las mismas. Aún con todo, y encorsetado por el espacio y el tiempo — unos pocos pliegos de papel y quizá la inmimencia de la muerte-, el testador manifiesta sus intenciones y preferencias al notario, cristalizándose los diferentes y más variados tipos protocolarios.

\subsection{El momento de la muerte}

\section{Fago e ordeno este mi ultimo e postremo testamento...}

$\mathrm{Al}$ acercarse el momento posible o cierto de la muerte — caso de un viaje, peregrinación, enfermedad grave o incorporación a una guerra ${ }^{49}$ - una parte significativa de los hombres de esta época manifiestan su interés y voluntad por ordenar sus asuntos materiales y espirituales ...e por tal que empues el mi traspasamiento, discordia, malencolia, ni malquerencia, ni debat alguno no aya de baber entre mi muger, fijo e fija ni los otros parientes mios, temiendo las pennas infernales e cobdiciando yr ala gloria del sancto paradisso ${ }^{50}$. $\mathrm{Y}$ en ese deseo, y también necesidad, de rendir cuentas a Dios y a su mundo circundante, manda escribir lo que denominamos testamento, última voluntad o herencia. Los notarios, ante quienes se presenta el deseo de redactar ese escrito, aplican toda su pericia profesional para la satisfacción del cliente. $Y$ ateniéndose a los formularios y modelos existentes se ponen a su servicio. Todo sobre lo que legue, notifique y disponga,

49 ...estando sano y bueno visto delibera yr para enguerra contra moros allende en la capitania del conde Pero Navarro adonde podria morir (Testamento de Blas de Ocáriz, AGN, Protocolos Notariales, Tudela, c. 29, Miguel Martínez Cavero, s. f., de 28 de mayo de 1507) o ...seyendo sana et alegre et en bueno et sano entendimiento por quanto so en proposito de byr en romeria a sennor Santiago de Galicia et Oviedo (Testamento de María de Arnalt, AGN, Protocolos Notariales, Tudela, c. 1, año 1434).

so AGN, Protocolos Notariales, Elizondo, Juan de Elizondo, leg. 1, n. 53, del 21 de diciembre de 1509.

Hispania, LXV/1, núm. 219 (2005) 155-226 
que apuntarán minuciosamente los secretarios o escrivans, es apto de introducirse en el texto; un testimonio vital y propio, redactado en primera persona del singular por el disponente.

...que como yo aya fecho iordenado el mi ultimo i postremero testament segunt paresce por carta publica irreçebida en notario por mano de Garcia Martiniz de Uxue, notario de [roto] XXVIII ${ }^{\circ}$ dia del mes de deziembre. Era mil IIIIC. XXI.

Yo la dicta Iohana Martinez con licencia, auctoridad e consentimiento de vos el dito Pero Garcia mi marido qui estando es present en el notario infrascripto e cada uno de nos segunt nos toqua...

Seppan en que yo Gracia Martinez de Arguiñano, mujer de Iohan de Guembe, vezina de Arguiano la dicha Gracia con licencia del dicho su marido e aquellos dant e otorgant segunt guesta e presente en mi el notario maguer enferma en su persona... 51

El notario se presenta como el mediador legal de un testamento que puede ser modificado, siempre que se respeten y no se alteren los procedimientos instrumentales previstos para estos casos. Pedro Périz de Echauri otorga, con fecha del 2 de abril de 1510, un codicilo de amejoramiento del testamento que él y su mujer María de Lacunza habían hecho ${ }^{52}$ :

...como en dias passados Maria de Lacunza mi muger e yo los dos juntament hubimos ffecho nostro testament enel final habimos dado poder el uno a la otra e la otra al otro que el sobre vivient pudiesse ordenar e mandar delos bienes muebles a su propia voluntat $\mathrm{e}$ las casas e vinas y otras heredades que nos junta o divisament teniamos (...) según paresce a don Iohan de Lizurzun, notario, e después de ffecho este testamento la dicha Maria Lacunza mi muger al tiempo Dios fuera ordenar della por su cobdicilo, mando que se podiesse ordenar ami propia voluntat delas vinas (...) segunt paresce por el cobdicillo della recebido aquel en memorial por don Iohan de Orcoyen e después abonido por el notario inffradicto...

La voluntad e intenciones del testador han de quedar expresamente claras y concisas, sobre todo porque la resultante final tiene una proyección más que puntual, como indica el testamento de María Sanz de Echauri ...el quoal dicto testament quiero e me plaze me valga e sea valedero para todos los tiempos del mundos3. Los componentes religiosos dispuestos por el individuo no son el mero preám-

51 AGN, Protocolos Notariales, Tudela, Martín don Costal, f. 281-282, codicilo de Oria de Leache, mujer de Rodrigo de Esparza, vecina de Tudela (29 de diciembre de 1381) y AGN, Protocolos Notariales, Salinas de Oro, Juan Miguel de Salinas, c. 2, n. 44 (6 de abril de 1495) y n. 171, de 14 de enero de 1494.

52 AGN, Protocolos Notariales, Salinas de Oro, Juan Miguel de Salinas, c. 4, s. c., hecho en Echauri.

53 AGN, Protocolos Notariales, Salinas de Oro, Juan Miguel de Salinas, c. 4, s. f., hecho en Echauri el 23 de enero de 1511.

Hispania, LXV/1, núm. 219 (2005) 155-226 
bulo del más que lógico y esperado reparto patrimonial de unas posesiones que son dádivas de Dios administradas durante la vida ...por dar la mejor cuenta que a mi hora posible a mi Dios redeptor, disponiendo de los bienes de fortuna que en este mundo le plugo encomendarme $e^{54}$. Sino que manifiestan su piedad personal y tratan de mostrar el anhelo por elevar su alma hacia el cuerpo eclesial glorioso, como se refleja en el testamento de los tudelanos Pero Sanz de Murgutio, escudero, ...a quiem Dios en su Sancta Gloria tenga disponiendolo la voluntad divina adolescio de una grave y rezia dolencia de la qual dio el spiritu a su Dios creador y Pedro de Toledo ...deseando yr a la gloria perdurable de parayso que para siempre ha de durar. Y con más elocuencia en el de Lope de Iribarri, barbero de esa ciudad, et que todos los fieles cristianos dessean haver receptaculo e babitación en la sancta madre yglesias5.

De ahí la insistencia, entre las primeras líneas de los textos, por mostrar la posesión de las plenas facultades mentales ...estando en mi buena memoria e stando sana en mi persona, sana mediant la gracia de Dios ${ }^{56}$. Algunas enfermedades o la edad avanzada que merman el estado físico de las personas, no han de determinar en su totalidad los contenidos de un testamento. La muerte cercana no es el detonante de un miedo, sin duda real, con la consiguiente plasmación de unas «obligadas» mandas pías. Más bien, y con las palabras del rector de Arteta, Johannes, todo fiel cristiano debe dictar sus cosas en este mundo, ni entre tiempo ba lo mejor que puede de manera que sea a servicio de Dios nuestro Señor ${ }^{57}$.

\section{..las almas son mejores que los cuerpos, y más preciadas.}

A tenor de las primeras líneas y párrafos que con ligeras variantes se repiten en los testamentos, se observa que una mayor parte de los mismos se redactan cuando el individuo está enfermo. Dolencias que se expresan con diferentes formas ${ }^{58}$ :

...seyendo enfermo del cuerpo litigado...

...en como el dicho Ferrando su dicho marido estando enfermo en la cama de una cayda que cayo de la cambra...

${ }^{54}$ AGN, Protocolos Notariales, Tudela, Juan Martínez Cavero, c. 4, f. 124r.-126v. Codicilo de Alfonso de Guadalajara, escudero y caballerizo del rey Juan.

55 AGN, Protocolos Notariales, Tudela, Juan Martínez Cavero, c. 6, fajo de 1512, f. 52r. y siguientes, de 20 de septiembre de 1508 ; c. 5, f. 126, de 18 de septiembre de 1509 y c. 6, fajo 1512 , f. $64 \mathrm{v} .-65 \mathrm{r}$.

56 AGN, Protocolos Notariales, Salinas de Oro, Juan de Vidaurreta, c. 3 de 5 de julio de 1509.

57 AGN, Protocolos Notariales, Salinas de Oro, c. 4, s. c., de 26 de agosto de 1510.

58 AGN, Protocolos Notariales, Tudela, Pedro Lorenz, c. 1. Palabras del propio testamento del notario, fechado en 1439; Salinas de Oro, Juan Miguel de Salinas, c. 2, fajo de 1503; Tudela, Miguel Martínez Cavero, c. 29, s. f., de 1507; Tudela, Sancho Ezquerro, c. 12, f. 76r.-79v. de 1383; Tudela, Juan Martínez Cavero, c. 4, fajo 1494-1500, f. 1v.-3r. de 1500 y Santesteban, c. 1 de 1453. 
...estando enfermo, en buen seso, pero andando por sus pies...

...estando ocupado en mi persona pero gracias a Dios en mi buen seso, sana e firme memoria e palabra manifiesta, desseando preveyr al beneficio e refrigerio de mi alma...

...estando quostituido en estrema vejez et en alguna dolencia de su persona pero en su buen seso...

...enfermo en mi persona, seyendo en mi buen acuerdo, seso e entendimiento que Dios en mi ha miniserado...

Si bien no cabe considerarse como un comportamiento habitual, la aparición de dolencias y la ausencia de la salud constituye una de las motivaciones más directas para apelar a un notario. Porque en estas centurias se tiende a relacionar la enfermedad con el pecado y la muerte ...seyendo enfermo del cuerpo litigado, temiendo las penas del infierno et copdiciando yr a la santa yglesia del santo paradiso, empero seyendo en mi buen seso et en mi buena memoria a laudor et reverencia del nuestro seynor Ihesu Christo et de la Virgen Santa Maria et de toda la cort celestial et oviendo firme et cierta creyenca que toda persona que en carne es puest segunt dize la santa scriptura sines muert corporal escapar non pueda...e non guardando a los mios peccados ${ }^{59}$.

Para una gran parte de las gentes y los médicos cristianos de las centurias altomedievales, en su mayoría clérigos y monjes, tuvo un gran peso la doctrina de la Iglesia, estableciendo una relación causal entre Dios-poseedor de la salud, Dios como medicina y pecado-enfermedad corporal. Ante un enfermo lo primero que hay que hacer es llamar al confesor porque cum infirmitas corporalis nonnunquam ex peccato proveniat (canon 22, IV Concilio de Letrán) ${ }^{60}$. Hasta entonces más que una ciencia, el arte de curar formaba parte de la cosmología y antropología cristianas. El enfermo es un hombre en el que está Cristo, y así lo recuerda la regla benedictina, el cuidado de los enfermos debe ser ante todo practicado como si, dispensándolo a ellos, al mismo Cristo se le dispensase ${ }^{61}$. El hombre, por tanto, es imagen de Dios por su inteligencia y libre voluntad, aunque también está marcado por el pecado original.

Humberto de Romans, dominico francés que llegó a ser Prior de la Orden de 1254 a 1263, expresa en uno de sus sermones que las Artes Liberales, como la Medicina o el Derecho surgen tras el deterioro de la condición humana por el pecado original. Y destaca el gran valor de la Medicina, por encima de cualquier otra de las artes liberales por su triple dimensión y alcance. Ayuda al conocimiento de la fragilidad de la condición humana, natura corporis bumani; conduce a quien la practica a las opera misericordie y finalmente, es un instru-

59 El fragmento está recogido de un testamento del notario Pedro Lorenz (AGN, Protocolos Notariales, Tudela, 1439, Pedro Lorenz, c. 1).

60 García Ballester, Luis, La medicina, Madrid, 1994: Historia de España, fundada por R. Menéndez Pidal, vol. 16, p. 161.

${ }^{61}$ Lain EnTralgo, Pedro: Historia de la medicina, Barcelona, 1978, p. 189. 
mento o medicina spiritualis animarum ${ }^{62}$. Motivaciones y prácticas que también recogen Las Partidas o De instructione medici de Arquimateo ${ }^{63}$ :

Antes de ir a casa del enfermo pregunta si manifestó su conciencia al sacerdote, y si no lo hubiere hecho, que lo haga o que prometa hacerlo; porque si hablas de ello una vez visto al enfermo y luego considerados los signos de la enfermedad, pensarán que hay que desesperar de la curación porque tú desesperas de ella.

A lo largo del siglo XIII y durante el XIV, la medicina deja de ser un oficio de sanar para transformarse en un ars medica, en una verdadera ciencia. Atrás quedan las prácticas empíricas o pretécnicas para dejar paso a un conocimiento racional de la enfermedad y el tratamiento del sistema hipocrático-galénico. Sobre todo gracias a las traducciones de tratados árabes de fisiología, patología, clínica, farmacoterapia y cirugía, realizados en la escuela de Salerno desde el siglo XI. Y un poco más tarde por la magnífica obra y labor de Arnau de Vilanova (c. 1240-1311), primero en llevar a cabo una elaboración cristiana y escolástica del galenismo y avicenismo.

También toma cuerpo la formación de los sanadores, que basaron su actividad médica o quirúrgica sobre la filosofía natural aristotélica. La medicina se incorporó a la enseñanza universitaria en toda Europa en el primer tercio del siglo XIII, aunque se detecta la continuidad de una indefinición profesional en este campo, que explica el mantenimiento paralelo y entremezclado de sanadores con llamémosles "profesionales universitarios». A la vez apareció en los reinos de Castilla y Aragón la primera legislación relacionada con el arte de curar, como la contenida en el Fuero Real de Alfonso X (1254-1255) y Cortes de Monzón de 1289 bajo Alfonso III, además de otras regulaciones menores de carácter municipal. De esta manera, en la península se incorporaba la tradición europea inaugurada en Sicilia por Rogelio II (1140) y que conllevaba para el saber médico unas garantías de salud pública y un elemento del equilibrio social, al desbordar el plano de los grupos en un principio más privilegiados.

Con la tecnificación y racionalización del mundo de la enfermedad, a través de los conocimientos aportados por los textos árabes se introdujo en Europa occidental la idea aristotélica según la cual los fundamentos teóricos de un ciencia suministraban los elementos necesarios para llevar a cabo su práctica. Es decir, el galenismo. Corpus que se esforzó por presentar la salud y la enfermedad como fenómenos naturales estrictamente corporales, comprensibles y modificables por la razón del hombre. Aparecieron progresivamente los instrumentos técnicos y recursos para abordar y satisfacer el deseo de salud de la población. Y de esta manera se fueron, poco a poco, apartando los elementos mágicos y supersticiosos. Eso sí, sin olvidar una de las bases de la antropología científico-médica fundamen-

62 ZIEGLER, Joseph: Medicine and religion c. 1300. The Case of Arnau de Vilanova, Oxford, 1998, p. 2.

${ }^{63}$ LAIN ENTRAlgo, P.: Historia de la medicina, p. 240. 
tada en el pensamiento teológico: «Dios es el médico eterno», por que tal y como afirmaba Estéfano (1346-1380), médico del arzobispo de Sevilla ...E del qual (Dios) proviene toda mediçina e todo conoçimiento bueno ${ }^{64}$.

$Y$ es que en el ámbito religioso y espiritual se utilizó el lenguaje médico para su discurso: la imagen de Cristo como el médico-sanador, trazando una analogía entre el cuerpo místico y el físico; así Cristo aplica la medicina o sacramentos para revitalizar el pulso cristiano o caritas y purga del alma los humores del diablo. Porque en el mundo material todo se corrompe, pero el alma se regenera ...empero por gracia de Dios esto constituyda en mi entera e buena voluntat et mental dispossicion e en mi intellectial fortaleza. Atendient e considerant que facilmente el cuerpo humano ffaze mutacion e que toda persona es mortal e corruptible et dela su corrupcion cada buno sea cierto. Empero ala ora dal transpasamiento suyo ninguno non tenga caridat... ${ }^{65}$.

Al mismo tiempo, resalta el creciente esfuezo por mejorar la red de asistencia médica sostenida por concejos, nobleza o corporaciones gremiales, aunque los centros hospitalarios que podían ofrecer ayuda técnica eran pocos, relativamente pequeños y limitados por los escasos medios y recursos ${ }^{66}$. Aun con todo, es de notar que tan sólo se haya documentado una sola presencia en una de estas instituciones: Catalina de Monreal (1479) otorga testamento ...present de grabe enffermedat de mi persona en la cama en el ospital de Santa Maria de Gracia de Tudela. Empero gracias fago a nostro Redentor Ihesu Cbristo en mi buen seso ${ }^{67}$. Y no cabe pensar que fuese una indigente, sino más bien una persona que necesitara cuidados especiales o que no contase con la asistencia familiar adecuada.

Se trataba en definitiva, dentro de la rica tradición asistencial peninsular, de que los enfermos no estuviesen desamparados, al calor del mandato evangélico de la caridad ... ayude (el médico\} en quanto pudiere a los pobres, e de los ricos non reşele pedir buenos salarios ${ }^{68}$.

Médicos y también por extensión apotecarios cada vez mejor integrados en la retícula social de los núcleos urbanos de finales del XV y comienzos del XVI,

${ }^{64}$ GARCíA BALleSTer, L., La medicina, p. 161

65 AGN, Protocolos Notariales, Tudela, Juan Aristoy y Navarro, c. 37 (1499-1524), f. 184r.186v., fechado el 11 de julio de 1506 en Tudela. Testamento de Águeda López de Cascante, vecina de Tudela.

66 Caso de los centros asistenciales de Pamplona. Cfr. MARTinena, Juan José: La Pamplona de los burgos y su evolución urbana (siglos XII-XVI), Pamplona, 1975. Hospitales de la Navarrería, pP. 143-150; de San Cernin, pp. 251-254 y de San Nicolás, pp. 313-315. También MaríN, Luis María: Historia de la villa de Tudela. Desde sus orígenes hasta 1390, Tudela, 1978, pp. 187-188/246-249/ 289-290/349/361-362/456.

67 AGN, Protocolos Notariales, Tudela, Pedro Jiménez de Castelruiz, c. 11, f. 11r.-12v., fechado el 26 de junio de 1479.

68 GARCÍA BALLESTER, L., La medicina, pp. 664-665.

Hispania, LXV/1, núm. 219 (2005) 155-226 
caso de los tudelanos Francisco de Lenoz ${ }^{69}(1508)$ y Juan Ángel $(1510)^{70}$, respectivamente, de quienes se ha conservado testamento:

In Dei nomine. Sea cosa maniffiesta a quantos esta presente et publica carta de testamento veran et oyran como porel pecado de nuestro padre Adant toda natura humana sea obligada e subiugada ala muerte corporal dela qual persona alguna en carne en esta miserable vida puesta evadir ni escapar no puede et como no haya cosa mas cierta alos peregrinantes enla presente vida que la muerte ni mas incierta que la hora deaquella. Acerca de lo qual el verdadero Redemptor esalbador nuestro Ihesu Christo ensu sagrado evangelio amonestando nos dize estat apelados ca no sabeys el dia ni lahora quando vendra el Sennor avos llamar. Ca bienaventurados sean aquellos servidores alos quales quando vendra el Sennor alos llamar los hallara velantes. Para questo yo maestre Francisco de Lenoz medico ciudadano de la ciudat de Tudela estando enfermo delarga egrave enfermedat en la cama pero doy gracias infinitas porello ami Sennor Ihesu Christo en mi buen seso, entendimiento sana e firme memoria e palabra maniffiesta temiendo las penas infernales et desseando yr a la gloria perdurable de parayso. Queriendo prevenir et sobrevenir al benefficio e consolacion demi anima delas cosas aellas necessarias porque unas dignamente mereca e pueda han la gloria de ...e para siempre duradera et queriendo assi bien disponer delos bienes de fortuna que Dios me ha dado y encomendando por orden testamentaria portal que entre mis fijos e fijas no haya de haver discordia alguna sobre ellos. Primerament humil et devotament encomiendo mi anima en manos de mi sennor Dios Padre que la creo e formo asu imagen et semejanza llamandole devotamente merced e misericordia que porsus santissimas misericordias epiedat et porlos meritos dela sagrada passion de mi redemptor et salvador Ihesu Christo su muy amado fijo et por meritos et intercession dela gloriosa e bienaventurada Virgen Maria su sennora madre y advogada nuestra y de todos los santos y santas dela corte celestial me quieran perdonar mis culpas, fallas e pecados emi anima quiera collocar con sus bienaventurados santos en la su perdurable gloria de parayso.

\subsection{Ritual funerario.}

El apartado dedicado al funeral, recoge de forma muy precisa el carácter ritual de la muerte pues en esta etapa final de la vida no sólo se expresa la voluntad individual de cada testador, sino también la mentalidad colectiva de la comunidad a la que pertenece. Así pues, el rito se compone de un «conjunto de normas prescritas para la realización de los actos del culto en una religión o una iglesia» que toda sociedad organiza para afianzar un orden interno ${ }^{71}$. Esta aplicación del rito a la muerte en la Edad Media, especialmente en los siglos

69 Testamento de Francisco de Lenoz, AGN, Protocolos Notariales, Tudela, Juan Martínez Cavero, c. 5, f. 119, año 1508 .

70 Testamento de Juan Ángel, AGN, Protocolos Notariales, Tudela, Juan Martínez Cavero, c. 5 , f. 65 , año 1510

71 Otra acepción de esta palabra es: «acto religioso repetido invariablemente con arreglo a normas prescritas». Cfr. MOLINER, María: Diccionario del Uso de Español. María Moliner, (Madrid) 1998. 
bajomedievales, provoca que este momento se revista de un tono social y público, en el que el protagonista es el muerto, pero que requiere de otros personajes secundarios que realzan la trascendencia del fallecido y que lo acompañan en ese tránsito hacia el Más Allá. A esto contribuye también el hecho de que el ritual funerario no se centra exclusivamente en el día del fallecimiento y del entierro, sino que se amplía todo un año, concluyendo con la misa de aniversario $^{72}$. A a pesar de ello, es general que las prácticas rituales y litúrgicas por las cuales se recuerda el alma de los fallecidos, se prolonguen todavía más en el tiempo a través de generaciones y con ellas se perpetúe la presencia de los muertos en la sociedad de los vivos:

En los siglos XIV y XV se producen en Europa una serie de cambios mentales que influyen en el comportamiento religioso y en la percepción y vivencia de la muerte ${ }^{73}$. Con ellos, comienza una transformación del ritual funerario, que deriva hacia unas prácticas más teatralizadas en las que adquieren importancia el cadáver y las procesiones, con los consiguientes signos externos que las acompañan: el cortejo, las luminarias, los gestos y vestimentas de duelo ${ }^{74}$.

Por un lado, se configura un código más complejo de identificación, en una sociedad estratificada que en estos momentos ya goza de una mayor movilidad y dinamismo entre los diferentes estamentos. Por otro, estas prácticas arrastran consigo en algunas ocasiones supersticiones. De este modo, el ritual funerario, sujeto a las normas de la comunidad, establecía que la posición social de la que se disfrutaba en vida quedara remarcada en la muerte a través de unas actitudes espirituales y de una serie de gestos externos que eran propios y distintivos de cada estamento: las diferencias que. se ostentaban en vida se trasladan a la muerte. Sin embargo, el dinamismo socioeconómico trajo consigo injerencias de órdenes sociales inferiores en otros superiores.

Todo ello amenazaba el orden social y doctrinal, pero también la economía y supervivencia de las propias familias, así que las autoridades eclesiásticas y civiles tuvieron que intervenir a través de la publicación y difusión de ordenanzas municipales, ordenanzas suntuarias, legislación civil o constituciones sinodales para controlar o, incluso, erradicar estas prácticas, excesivas en algunas ocasiones, aunque estas medidas no siempre resultaron efectivas ${ }^{75}$.

La muerte, como tal, es un acto público y es asumida por todo el colectivo. Así, en torno a este hecho inevitable en la vida de una persona, se configura un ritual en el que todos participan activamente, ya que el carácter cristiano de

72 RoYer De CARdinAL, Susana: Morir en España. (Castilla Baja Edad Media), Buenos Aires, 1992, p. 145. Y también en CHIFFOLEAU, Jacques: La comptabilité de l'au-delà. Les hommes, la mort et la religion dans la région d'Avignon à la fin du Moyen Âge, vers 1320-vers 1480, París, 1980, p. 149.

73 ChiffoleaU, J.: La comptabilité de l'au-delà, p. 149, establece estos cambios en la región de Aviñón a partir de principios del siglo XIV y finales del XV, pero estas fechas están sujetas a particularidades locales y las datas pueden variar ligeramente en los diferentes territorios europeos.

${ }_{74}$ Ibidem.

75 González ArCe, J. D.: Apariencia y poder, p. 211.

Hispania, LXV/1, núm. 219 (2005) 155-226 
esta sociedad favorece las solidaridades colectivas a través de agrupaciones familiares, vecinales y confraternales ${ }^{76}$. Desde el propio moribundo -que redacta previamente testamento y se prepara para el trance recibiendo los sacramentos preceptivos (como confesión, comunión y unción de enfermos) - hasta los parientes más próximos, vecinos y religiosos locales, todos forman parte de los actos de las ceremonias funerarias. Este ritual, que se compone de un complejo mundo de símbolos sociales y religiosos ${ }^{77}$, es el que las jerarquías religiosas y civiles recomiendan seguir para ganar una «buena muerte» cristiana ${ }^{78}$.

\section{...sea fecho el servicio de las gentes...}

Una vez que se ha producido el fallecimiento, confortado con la recepción de los últimos sacramentos, el primer paso que se establece es la preparación del cuerpo para su exposición pública. Así, una vez adecentado y lavado ${ }^{79}$, es cubierto por su mortaja, que puede consistir en un sudario de lienzo ${ }^{80}$, un hábito religioso o en algunas ropas del propio difunto. Los testamentos navarros arrojan muy pocos datos al respecto ${ }^{81}$, quizás por ser común el uso de sudarios de algodón y lino o de vestimentas convencionales. Destaca por su excepcionalidad el testamento de la vecina de Tudela Bartolomea de Arlás, viuda de Lope de Ujué, que deja a su sobrino Jimeno de Olite, un $p$ del de lino el que es qompaynnero del de mi mortailla ${ }^{82}$. Este testamento viene a confirmar esta teoría porque Jimeno de Olite, pocos años después, en su testamento, no indica nada

76 SESMA MUÑOZ, José Ángel: «Cofradías, gremios y solidaridades en la Europa Medieval» en Cofradías, Gremios y Solidaridades en la Europa Medieval. XIX Semana de Estudios Medievales. Estella, 20 a 24 de julio de 1992 (Pamplona) 1993, pp. 28-29.

77 LE GOFF Jacques et alia: El hombre medieval, Madrid, 1990, pp. 40-42.

78 ROYeR DE CARDINAL, S.: Morir en España, p. 145.

79 AGN, Protocolos Notariáles, Santesteban, c. 1, s. c. El único testimonio hallado en los protocolos navarros ha sido la mención al pago de dos sueldos a un barbero en una lista de gastos de los funerales de Juan de Aguirre, señor de Agorreta, datada hacia 1531. Si bien en un principio esta tarea estaba limitada a las mujeres más adelante también podía ser realizada por barberos, en el caso de que el fallecido fuese de sexo masculino. Ver así, esta idea y ejemplos en ALEXANDrE-BIDON, Danièle: La Mort au Moyen Âge. XIIIe siècle, París, 1998, pp. 109-110 y MARANDET, Marie-Claude: Le souci de l'au-delà: la pratique testamentaire dans la région toulousaine (1300-1450), Perpignan, 1998, pp. 188-189.

${ }^{80}$ Pedro Sánchez Gatiño, mercader orensano establece et mando que me deyten desnudo su terra, salvante meus pannos pequenos, 5 de noviembre de 1429 en LÓPEZ CARREIRA, Anselmo: $A$ cidade de Ourense no século XV. Sociedade urbana na Galicia baixomedieval, Orense, 1998, ver n. 7 del apéndice documental.

${ }^{81}$ Son numerosos los autores que recogen en sus investigaciones este problema. Vid. MARANDET, Marie-Claude: Le souci de l'au-delà, pp. 188-189, POLANCO MELERO, Carlos: Muerte y sociedad en Burgos en el siglo XVI, Burgos, 2001, pp. 161-162, GARCíA GuZMÁN, Ma del Mar; ABELLÁN PÉREZ, Juan: La religiosidad popular de los jerezanos según sus testamentos (siglo XV), Cádiz, 1997, pp. 23-24 y BEJARANO, Amparo: El bombre y la muerte: los testamentos murcianos bajomedievales, Cartagena, 1990, p. 43, entre otros.

82 AGN, Protocolos Notariales, Tudela, Martín Garceiz Don Costal, cuad. 1381-1383, f. 15-17, codicilo de 27 de marzo de 1381. 
sobre el sudario de lino con el que su cuerpo sería envuelto ${ }^{83}$. Sin embargo, es también frecuente que algunas personas elijan como mortaja hábitos de órdenes religiosas, sobre todo en el medio urbano, tal y como lo demuestran 7 testimonios notariales pertenecientes a la ciudad de Tudela, en los cuales figura el hábito franciscano ${ }^{84}$. Es significativo añadir que, además, todos estos testadores prefieren a esta orden religiosa, no sólo como figura de intercesión por sus almas, sino también como espacio de reposo de sus cuerpos, ya que todos ellos piden ser enterrados en el monasterio de San Francisco de dicha ciudad ${ }^{85}$.

No existen datos suficientes que nos permitan obtener una conclusión definitiva sobre el uso de ataúd, por lo que no conocemos con exactitud si es una práctica extendida entre la población o bien si está restringida ${ }^{86}$. Sin embargo, existen algunos datos que hacen muy probable que su encargo esté limitado a las personas más favorecidas ${ }^{87}$. De tal modo, los únicos testadores que eligen ataúd son vecinos de la localidad de Puente La Reina y son enterrados en el interior de la iglesia de Santiago como María de Urtubia, que ordena: mando que mi cuerpo sea sepelido e soterrado en atabut dentro en la yglesia parrochial de Santiago... ${ }^{88}$. El resto de testadores, más humildes, se contentarían con alquilar andas y ataúdes de uso común, bien propiedad de una parroquia o de una cofradía que serían portados por sus hermanos cofrades o por los parientes hasta la iglesia ${ }^{89}$; una vez que se

83 AGN, Protocolos Notariales, Tudela, Martín Garceiz Don Costal, cuad. 1381-1383, f. 270 271 , testamento de 29 de noviembre de 1383

${ }^{84}$ Algunos ejemplos son: Juliana de Magallón AGN, Protocolos Notariales, Tudela, Pedro de Latorre, c. 14, cuad. 1493-1494, f. 42v.-43v., 10 de junio de 1494. Juana de Agramont, mujer del señor de San Adrián, AGN, Protocolos Notariales, Tudela, Pedro de Latorre, c. 15, f. 26, 26 de marzo de 1505. Catalina Gil, AGN, Protocolos Notariales, Tudela, Miguel Martínez Cavero, s. f., 7 de julio de 1507.

85 Este monasterio tenía gran poder y predicamento en esta localidad. Esta misma práctica la recoge para Portugal, CASTRO PINA, Isabel: «Ritos e imaginário da morte em testamentos dos séculos XIV e XV» en MATtoso, José (dir.): O Reino dos mortos na Idade Média peninsular (Lisboa) 1996, p. 160. Para Murcia, Bejarano Rubio, A.: El bombre y la muerte, p. 40 y para Madrid, Gómeż NiETO, Leonor: Ritos funerarios en el Madrid Medieval, Madrid, 1991, pp. 52-53.

86 ÁlvAREZ FORTES, Anna $\mathrm{M}^{\mathrm{a}}$ : El sentit de la mort en L'Elx medieval. Un llibre de cláusules testamentàries de l'església de Santa María (1294-1444), Alicante, 1997, p. 82. BEJARANO, A.: El bombre y la muerte, pp. 41-42, no ha hallado ninguna referencia en sus testamentos a féretros. Sí ha encontrado, aunque escasas, Gómez NieTo, L.: Ritos funerarios, p. 53, dando datos de su uso en un $9 \%$ de testadores. CASTRO PINA, I.: «Ritos e imaginário da morte», p. 161, también lo documenta en Portugal, aunque los hallazgos son reducidos, al igual que en Navarra.

87 Así lo piensa también ROYER DE CARDINAL, S.: Morir en España, p. 157.

${ }_{88}$ María de Urtubia, mujer de Juan de Agorreta, barbero, AGN, Protocolos Notariales, Puente la Reina, Martín Brun, c. 1, n. 2, 28 de enero de 1507. Juan de Sarría, señor de Novar, AGN, Protocolos Notariales, Puente la Reina, Martín Brun, c. 1, n. 2, 28 de mayo de 1502. Gracia Sanz de Puente, AGN, Protocolos Notariales, Puente la Reina, Martín Brun, c. 1, n. 1, 1 de abril de 1501, que el mi cuerpo sea sepelido e soterrado en taut dentro en la yglesia parrochial de Santiago...

89 Cfr. ROYer DE CARDinal, S.: Morir en España, p. 160 y POlAnCo MELero, C.: Muerte y sociedad en Burgos, p. 139. Sin embargo, RoDrigo Estevan, $\mathrm{M}^{\mathrm{a}}$ Luz: Testamentos medievales aragoneses.

Hispania, LXV/1, núm. 219 (2005) 155-226 
procede al sepelio del cuerpo, se extrae el cadáver de la caja y se entierra directamente sobre la tierra, cubierto únicamente con la mortaja.

A continuación se procede al velatorio del difunto en casa, por parte de familiares, hermanos cofrades $^{90}$ y vecinos más cercanos, así como por algunos miembros de la comunidad religiosa, como lo indican algunos testamentos circunscritos al ámbito rural. Así lo establece María Pérez de Arzoz, viuda y vecina de Arzoz, que manda a su hija Sancha que aya de velar una noche con sus criaturas en San Sebasstian de Muzqui que yo fezi voto de les fazer velar ${ }^{11}$. O el capellán Fernando de Vidaurre, cuyos cabezaleros deben llamar y convocar a los clérigos de la comarca para que velen sobre su cuerpo. Al día siguiente, celebrarán misa por la cual se les pagará dos groses a cada clérigo y sendos groses a los otros religiosos asistentes ${ }^{92}$. Este personaje destaca por su prudencia y previsión, dejando apartados 40 florines para los gastos de sus funerales. Pero de Orh, señor de la casa de Aldaloit y vecino de Garzáin, aconseja en su testamento que, si falleciese en viernes o sábado, su cuerpo fuese enterrado el domingo. Durante esta espera se realizaría su velatorio. Sin embargo, esta práctica estaría permitida sólo a determinadas personas ${ }^{93}$, como es el caso de este testador:

...e si contesciesse que mis dias sean fenescidos en el dia viernes o sabado mando que el mi cuerpo sea sepelido en el domingo seguient por tal que mas complidamente sea fecho el servicio de las gentes que vernan al dicho enterrorio ${ }^{94}$.

\section{...et sean vestidos doze pobres que lieben los cirios para su sepellimiento}

Seguidamente, se procede al traslado del cadáver desde la casa familiar donde había sido velado hasta la iglesia donde se realiza la misa funeral y el entierro. Este cortejo está integrado por religiosos que portan una o varias cru-

Ritos y actitudes ante la muerte (siglo XV), Zaragoza, 2002, p. 102, nota 85, afirma que, en la zona sur de Aragón (Daroca), se generaliza el féretro a partir de la segunda mitad del siglo XV.

90 Son numerosas las ordenanzas de cofradías navarras y del resto de la península, que tienen por norma velar a sus hermanos. Como los estatutos de la cofradía de San Pedro y Santa Eufemia de Villafranca (Navarra), del siglo XIV. Cfr. LACARRA YANGUAS, $M^{\mathrm{a}}$ Jesús: «Dos cofradías del siglo XIV en Villafranca (Navarra)» en Príncipe de Viana (Pamplona) 138-139 (1975), pp. 141-164.

${ }^{11}$ AGN, Protocolos Notariales, Salinas de Oro, Juan Miguel de Salinas, c. 3, s. c. Testamento de María Pérez de Arzoz, viuda y vecina de Arzoz, de 4 de enero de 1504.

${ }^{22}$ Fernando de Vidaurre, capellán y beneficiado de la iglesia parroquial de Santa Catalina de Vidaurre y vecino de Vidaurre, AGN, Protocolos Notariales, Salinas de Oro, Juan Miguel de Salinas, c. 2, n. 90, 8 de marzo de 1497.

93 Cfr. Fuero General de Navarra, Libro III, Título XXI: De Sepulturas. Capítulo I. IlaRREgUI, Pablo; LAPUerta, Segundo (eds.): Fuero General de Navarra. Amejoramiento del Rey don Phelipe. Amejoramiento de Carlos III, Pamplona, 1964: Biblioteca de Derecho Foral, vol. I, p. 149.

${ }_{94}$ AGN, Protocolos Notariales, Santesteban, Juan de Ursúa, c. 1, n. 68, 27 de enero de 1491.

Hispania, LXV/1, núm. 219 (2005) 155-226 
ces parroquiales ${ }^{95}$, familiares, amigos y vecinos de los fallecidos, pobres ${ }^{96} \mathrm{y}$ compañeros cofrades.

El hombre medieval compone en su forma de vida y en sus actitudes mentales una simbiosis donde el matiz religioso y el sentido práctico están indisolublemente unidos. De tal modo, la presencia de estos personajes en la procesión tiene una doble funcionalidad. Por un lado, el cuidado con el que muchos testadores disponen su cortejo funerario es un síntoma muy claro de la preocupación por la honra y la fama que los hombres bajomedievales cultivan y promueven a nivel individual y familiar. A través de un nutrido cortejo y de una importante cantidad de luces de la mejor calidad se pugna por mostrar la autoridad, el prestigio y el poder económico de los que se gozaron en vida y que permanecen en la muerte. Por otro, una abundante presencia de pobres, que son vestidos a cargo del difunto, de religiosos y cofrades - a todos los cuales se proporcionarán limosnas abundantes ${ }^{97}$-, aseguran un abundante número de oraciones por su alma ${ }^{98}$.

La suntuosidad con que se organizan algunos de estos cortejos puede imaginarse a través de testamentos tales como el de Inés de Lacarra, mariscalesa de Navarra, que solicita ser acompañada por dieciocho pobres que portarán igual número de antorchas ${ }^{99}$. O el de María de Veraiz, viuda de Alonso de Guadalajara, que pide sean vestidos doce pobres que llevarán los cirios ...et que alli se le faga su enterrorio et sean vestidos doze pobres que lieven los cirios para su sepellimiento ${ }^{100}$. No menos espectaculares resultan el de Toda Martínez de Artieda, viuda de Juan de Falces, con XVI clerigos a menos del misacantano ${ }^{101}$ y el de Juana de Calatayud, viuda de Martín de Mezquita, con un cortejo mixto al que asistirán siete pobres y doce capellanes:

95 Fernando de Ciordia, vecino de Tudela, establece que seis pobres lleven los cirios y que la canongía lleve la cruz de plata. AGN, Protocolos Notariales, Tudela, Juan Martínez Cavero, c. 3, n. 4. Testamento fechado en 1493.

96 García de Irurre, rector de Aniz, Irurre y Lerga, en su testamento de 19 de enero de 1506, ordena vestir de paño gris a seis pobres de Pamplona. AGN, Protocolos Notariales, Salinas de Oro, Juan Miguel de Salinas, c. 3.

97 Ordenanzas de la cofradía del Corpus Cbristi o del Santísimo Sacramento ( ${ }^{\text {a }}$ mitad del siglo XIV). Cfr. SIlANES SuSASETA, Gregorio: «La cofradía del Santísimo Sacramento de Tudela» en Cuadernos de Etnología y Etnografía de Navarra (Pamplona) 71 (1998), pp. 53-58. Cfr. CHIFFOleAU, J.: La comptabilité de l'au-delà, p. 136.

98 Pedro de Beroiz, en su testamento, dispone que el día de su entierro sean vestidos ocho pobres y que rueguen a Dios por su alma sobre su sepultura. AGN, Protocolos Notariales, Tudela, Sancho Ezquerro, c. 12, f. 375r.-376v., 12 de julio de 1494.

99 AGN, Protocolos Notariales, Tudela, Sancho Ezquerro, n. 37, 24 de septiembre de 1482.

${ }^{100}$ AGN, Protocolos Notariales, Tudela, Juan Martínez Cavero, c. 6, fajo 1512, f. 11r.-117v., 26 de junio de 1512. Juana de Agramont también pide que doce pobres porten antorchas, AGN, Protocolos Notariales, Tudela, Pedro de Latorre, c. 15, f. 26, 26 de marzo de 1505.

101 AGN, Protocolos Notariales, Tudela, Martín Garceiz Don Costal, cuad. 1381-1383, f. 207209, 29 de agosto de 1383.

Hispania, LXV/1, núm. 219 (2005) 155-226 
...et que alli le sea fecho su enterrorio honrradament segunt a ella fazer se requiera en el qual quiere sean vestidos siete pobres en honor de los siete gozos de la sagrada Virgen Maria et que vayan a su sepellimiento et se le de de comer et dicto dia et assi bien que vayan doze capellanes los quales cada dia en los tres dias de la novena digan sendas missas et les sea fecha su cabo de novena ${ }^{102}$.

En algunos casos, la asistencia de pobres, clérigos y cofrades no se limita al día del entierro, sino que se amplía a toda la novena, como se señala en el testamento de Juana de Calatayud, anteriormente citado, o también en el de Francisco Lenoz ${ }^{103}$.

El cortejo, como se ha visto, conduce y acompaña, a un mismo tiempo, el cuerpo del fallecido a la iglesia con una serie de antorchas y velas, configurando una procesión de luz de gran efecto estético y simbólico. Las luces permanecerían envolviendo y protegiendo el cuerpo a lo largo de la misa funeral y con ellas se acompañaría solemnemente al difunto hasta la tumba. Estas antorchas, cirios y candelas poseen un componente simbólico muy complejo. Por un lado, la luz es el símbolo de Cristo Redentor y se contrapone al mundo de las tinieblas y del pecado, identificados con el demonio, según la inspiración de San Juan Evangelista ${ }^{104}$. Por otra parte, el número de antorchas, al igual que el de pobres y clérigos acompañantes y el número de misas instituidas, está íntimamente relacionado con el simbolismo que conformaba la mentalidad y la espiritualidad del hombre medieval. Su mundo estaba compuesto por signos (signa) y cosas (res), según idea de San Agustín, y el número es una manifestación más, como también lo son los ceremoniales o los colores ${ }^{105}$. Estos signos son plasmaciones externas y simbólicas de la verdadera realidad, un complejo mundo donde se superponían creencias muy distintas que el hombre medieval luchaba por aprehender en su vida cotidiana mediante gestos materiales ${ }^{106}$.

${ }_{102}$ AGN, Protocolos Notariales, Tudela, Juan Martínez Cavero, c. 6, fajo 1512, f. 76v.-78r., 27 de abril de 1512 .

${ }_{103}$ Testamento de Francisco Lenoz, médico de Tudela, AGN, Protocolos Notariales, Tudela, Juan Martínez Cavero, c. 5, f. 119, año 1508.

104 BALDÓ ALCOZ, Jụlia: «Un aspecto de los funerales a través de la legislación civil en la Navarra bajomedieval: el uso de antorchas durante el cortejo» en $V$ Congreso de Historia de Navarra, 10-12 septiembre de 2002, Pamplona (Pamplona) 2002, vol. II, pp. 197-210/ 198. Cita de San Juan recogida por ROYER DE CARDINAL, S.: Morir en España, p. 178, (Jn 8, 12) y texto de Alejo Venegas sobre este asunto, que incluye GómEZ NiETO, L.: Ritos funerarios, p. 54 y su correspondiente nota 2.

105 Vid. LE GOFF J., et alia: El hombre medieval, pp. 40-42.

106 CANTERA MONTENEgro, Margarita: «Religiosidad en la Rioja bajomedieval a través de los testamentos (siglos XIII-XV)» en Berceo (Logroño) 110-111 (1989), pp. 111-154/ 141. Indica el simbolismo que algunos números poseían, 3 por la Trinidad, 5 por las llagas de Cristo, 12 por los doce apóstoles, etc. RUBio SEMPER, A.: «Piedad, honras fúnebres y legados», p. 251, aporta un mayor número de explicaciones a números simbólicos: 5 por las cinco palabras de Jesucristo en la cruz, 7 por los siete gozos de Jesús, 9 por los nueve coros angélicos o por las nueve profecías, 11 por las once mil vírgenes, etc. 
Los testadores son especialmente cuidadosos en detallar, además del tipo de cera, las cantidades y los pesos, especialmente en las áreas rurales por contraposición a los habitantes de Tudela, que apenas dan indicaciones. La antorcha es el tipo de cera más utilizada frente a los cirios ${ }^{107}$, de precio más elevado y demandados por una minoría correspondiente a personajes con una buena posición socio-económica o a religiosos. Asimismo, es muy frecuente la compra de candela menuda, de menor tamaño e inferior calidad, que suele completar los pedidos de antorchas y cirios para potenciar así la luminosidad de la procesión de un modo más económico.

Respecto a las cantidades, es muy habitual el encargo de dos antorchas de cera ${ }^{108}$, aunque también es significativo el número de los que ordenan la adquisición de 3, 4 ó 6 antorchas ${ }^{109}$. En cuanto a los pesos, lo usual es que cirios y antorchas pesen 2 libras y media, aunque también se encuentran ejemplos de velas de una o de dos libras ${ }^{110}$.

Asimismo, una elevada proporción de testadores dispone la cantidad de antorchas según la usanza del lugar donde vive, que puede variar en función de los valles y de las ciudades. Tal es el caso de Gracia Sanz de Puente la Reina que pide la celebración de su entierro con 6 antorchas y 12 cirios de peso, como es costumbre en esta localidad, y candela menuda ${ }^{111}$. Diego Jiménez de Sozer, encarga que mis cabeçaleros traygan sobre mi cuerpo quoatro torchas honestas ${ }^{112}$. Gracia de Muruzábal encarga la compra de un total de 8 antorchas de cera, de cada

107 En 16 testamentos, siete de ellos pertenecientes a religosos. Suponen un 2,9\% de testadores. Pascuala, viuda de Lope de Arbizu y vecina de Puente la Reina ordena que para su entierro se compren 4 antorchas, 8 cirios y candela menuda. Juanes de Arteta, rector de Arteta, encarga que sus cabezaleros le hagan entierro con 6 antorchas de cera de 2 libras y media de peso, y dos cirios de 2 libras y media cada uno. AGN, Protocolos Notariales, Puente la Reina, Martín Brun, c. 1, n. 1, 23 de abril de 1491. AGN, Protocolos Notariales, Salinas de Oro, Juan de Salinas, c. 4, s. c., 26 de agosto de 1510.

${ }^{108}$ En 41 casos se encargan dos antorchas. Dos antorchas de dos libras de cera cada una, en el testamento de Martín Íñiguez de Iturgoyen y Toda López, su mujer, vecinos de Iturgoyen. AGN, Protocolos Notariales, Salinas de Oro, Juan Miguel de Salinas, c. 1, n. 8, año 1471. Y en el de Miguel Pérez de Goñi «Miquele Andía» y Gracia Martínez de Goñi, AGN, Protocolos Notariales, Salinas de Oro, Juan Miguel de Salinas, c. 1, n. 114, 15 de octubre de 1477.

1093 antorchas en 18 casos, 4 antorchas en 31, 5 antorchas en 5 ocasiones y 6 antorchas en 11. Asimismo, algunos testadores requieren otras cantidades mucho más infrecuentes: 1 antorcha en 2 oportunidades, 7 antorchas en 2, 8 antorchas en 2 y un caso excepcional de 18 antorchas.

110 Catalina de Ichaso ordena la compra de una antorcha de dos libras y media. AGN, Protocolos Notariales, Salinas de Oro, Juan Miguel de Salinas, c. 1, n. 35 bis, año 1472. María Miguel de Atondo, viuda de Miguel de Izco y vecina de Vidaurreta, manda la compra de 7 antorchas de dos libras y media de peso y candelas. AGN, Protocolos Notariales, Salinas de Oro, Juan Miguel de Salinas, c. 2, n. 161, 11 de noviembre de 1499.

111 AGN, Protocolos Notariales, Puente la Reina, Martín Brun, c. 1, n. 1, 1 de abril de 1501.

112 AGN, Protocolos Notariales, Salinas de Oro, Juan Miguel de Salinas, c. 1, n. 31, 2 de julio de 1472. Testamento de Diego Jiménez de Sozer, vecino del palacio de Echávarri y escudero del señor de Echarren.

Hispania, LXV/1, núm. 219 (2005) 155-226 
dos libras y media de peso y candela menuda, a sus hijos Martín (6 antorchas) y Juan de Leoz (2 antorchas):

Otrossi mando que para el otro dia de mi enterrorio me sean fechas ocho entorchas de peso segunt uso e costumbre del dicho lugar de Obanos es assaber de cada dos libras e media de cera e candela menuda quanta fuere menester ${ }^{113}$.

En las zonas rurales, una vez transcurridos el día del entierro y las celebraciones de la novena, estas luminarias son repartidas entre diferentes establecimientos religiosos, como la iglesia donde reposaría el cuerpo, las parroquias de los lugares de procedencia de los antepasados y las ermitas de la población y del valle ${ }^{114}$.

\section{...e den a comer e beber...}

Las celebraciones de banquetes y comidas en torno al funeral se pueden clasificar según el tipo de alimentos que se consumen y la forma en que son ofrecidos.

En primer lugar, las pitanzas consisten en comidas en honor del difunto que se celebran, tanto el día del entierro como el día del aniversario, por determinados conventos e instituciones religiosas elegidos por el testador. En Navarra este acto caritativo es un fenómeno netamente urbano y los protocolos lo circunscriben únicamente a Tudela, estando asociadas a monasterios ${ }^{115}$, al cabildo catedralicio de la ciudad ${ }^{116} \mathrm{e}$, incluso, a algunas cofradías ${ }^{117}$.

En segundo lugar, los banquetes, estrechamente ligados a las colaciones, se celebran tanto el día del funeral y entierro, como en los días de la novena, cabo de novena o cabo de año, en función de la elección del testador. Este ágape es ofrecido principalmente a los religiosos de la comarca que acuden al entierro. A él se sumarían algunos parientes y, en algunos casos concretos se señala también la presencia de vecinos, pobres y cofrades. La colación, en cambio, consiste en una refacción que se serviría en la plaza del pueblo o en la puerta de la igle-

113 AGN, Protocolos Notariales, Puente la Reina, Martín Brun, c.1, n. 3, 1 de octubre de 1500.

${ }^{114}$ AGN, Protocolos Notariales, Salinas de Oro, Juan Miguel de Salinas, c. 1, n. 43, fechado en 1473. Testamento de García Íñiguez de Munárriz, vecino de Munárriz.

115 Como en Barcelona, ofr. EQUIP BROIDA: «Els àpats funeraris segons els testaments vers el 1400" en Alimentació $i$ societat a la Catalunya médieval (Barcelona) 1988, pp. 264-265. Testamento de Juana Cirach, AGN, Protocolos Notariales, Tudela, Juan Martínez Cavero, c. 4, f. 134v.-137v., 29 de junio de 1505 .

116 AGN, Protocolos Notariales, Tudela, Juan Martínez Cavero, c. 6, fajo 1512, f. 120r.-v, año 1512. Testamento de Pedro de Egüés.

117 AGN, Protocolos Notariales, Tudela, Martín Garceiz Don Costal, cuad. 1381-1383, f. 215216, 4 de septiembre de 1383. Testamento de Nadal Sanchiz de Linares, vecino de Tudela, viudo de Estefanía de Pola y casado en segundas nupcias con Mayor de Cernau. 
$\operatorname{sia}^{118}$. A ella son invitadas todas las demás personas que no participan en el banquete principal (conocidos, parientes lejanos, otros vecinos del pueblo o de las localidades cercanas...) y que habían acudido a la misa funeral y al entierro. La práctica de la colación únicamente aparece mencionada, de forma explícita, en la zona del valle de Salinas de Oro, cercano a Estella. La primera alusión documental se ha hallado en un testamento datado en $1468^{119}$.

Estas comidas habían sido objeto de una estricta regulación en el siglo XIV a través del Fuero General de Navarra, que tenía por objeto el control de los gastos de los entierros para evitar la dilapidación del patrimonio económico del difunto. Pero esta medida también perseguía el control del orden social, limitando la asistencia a un número reducido de invitados, en función del grupo social al que el fallecido perteneciese ${ }^{120}$. Sin embargo, todo indica que la ley no era cumplida, puesto que en testamentos coetáneos no aparece mención explícita a la prohibición, aunque sí en documentos de carácter fiscal ${ }^{121}$. Para tratar de paliar estas prácticas se redacta una nueva normativa, un poco más permisiva, que amplía el número de asistentes ${ }^{122}$. Es la ordenanza real a la que se hace mención en numerosos testamentos de la notaría de Salinas de Oro a partir del año 1499:

E por quanto los enterrorios estan inhibidos, vedados e deffendidos por los Reyes nostros senniores que nengunos de los habitantes de su Regno no ayan de ffazer en dar a comer en nengun enterrorio a los que fueran a los tales enterrorios si no sea a los capellanes, escolares, parientes e a los qonffrades del lugar so ciertas penas en la dicha inhibicion e mandamiento contenidos e por goardar la inhibicion fecha por sus altezas nos los dichos Miguel dArbizu e Johana su dicha muger ordenamos e mandamos que los dichos nostros cabeçaleros inffradictos ninguno

118 e a los otros vernan al dicho mi enterrorio les den la colacion con pan, vino e queso en la plaza e no mas. Testamento de Juan Sanz de Munárriz y Leonor de Arguiñano. AGN, Protocolos Notariales, Salinas de Oro, Juan Miguel de Salinas, c. 2, s. c., 30 de septiembre de 1496. Codicilo datado en 12 de junio de 1503. En otras colaciones se incluyen también sardinas.

119 ...e den a comer e beber faziendo para eylo clamamiento a todos los clerigos de la quenca e escolares e parientes cercanos pan, vino, carne e pescado segunt el dia requeriere e a los otros que vynieren al dicho mi entierro les den la colacion en la plaza con pan e queso segunt las ordenanças del termino de Navarra... AGN, Protocolos Notariales, Salinas de Oro, Juan Miguel de Salinas, c. 1, n. 4.7 de mayo de 1468. Testamento de García Pérez de Zuasti, escudero.

120 Cfr. IlaRregui, P.; LApuerta, S. (eds.): Fuero General de Navarra. Ver el Amejoramiento del Rey don Phelipe (año 1330), capítulo XXI, pp. 266-267 y capítulo XXII, p. 270.

121 «En 1376 estaba prohibido hacer gastos de comidas en los entierros: Teresa, hija de Doña María Zubiel, fué multada por la córte por haber dado de comer en el entierro de D. Pedro Jimeniz abad de Erize», (AGN, Comptos, caj. 32, n 49, 2). Cfr. YANGUAS y MIRANDA, José: Diccionario de Antigüedades del Reyno de Navarra, Pamplona, 1995, , vol. I, p. 382.

122 Es muy posible que entre ambas fechas se ofreciesen banquetes, aunque siguiendo algún tipo de limitación, como se puede apreciar en algunos testamentos de Salinas de Oro. Baste citar el testamento de Ochoa de Izurzu, AGN, Protocolos Notariales, Salinas de Oro, Juan Miguel de Salinas, c. $1, n .129,25$ de agosto de 1478: ... den a comer e beber a los mis conffrares e conffradresas e a los capellanes y escolares de la comarca que al dicho enterrorio vernan...

Hispania, LXV/1, núm. 219 (2005) 155-226 
dellos no ayan de dar a comer ni beber a los que vernan a los dichos nostros enterrorios salvo a los clerigos, escolares e parientes cerquanos e a los qonffradres del dicho lugar de Munarriz de las viandas que el dia o dias requeran. E a los otros que vinieran a los dichos nostros enterrorios den la colacion con pan, vino e queso segunt la costumbre que despues de la dicha inhibicion se goarda en la puerta de la dicha iglesia de Santa Maria o en la plaça ${ }^{123}$.

Tal inhibición aparece citada de forma explícita en la práctica totalidad de los testamentos de este valle desde el año $1499^{124}$ y se reduce paulatinamente a partir de 1509. Y hacia 1513 son ya escasas las referencias tanto a la colación como a la ordenanza de los reyes ${ }^{125}$. Paralelamente, se retoman las antiguas fórmulas, tales como las viandas que el dia requiera, segunt el dia fuere ${ }^{126}$ o según el uso del lugar ${ }^{127}$. Lo que indica una cierta relajación de las costumbres así como de la aplicación de la normativa sobre banquetes, lo que es comprensible si se tiene en cuenta la crispada situación política que atraviesa el reino de $\mathrm{Na}$ varra en estos momentos.

En otros lugares, salvo excepciones, no se hace referencia explícita a la «inhibición real», aunque existen algunos datos que nos indican que sí fue conocida e, incluso, aplicada. En el caso de Puente la Reina, una zona bastante cercana al valle de Salinas de Oro, son varios los ejemplos que lo demuestran de formà explícita o implícita ${ }^{128}$. En ellos puede observarse una regulación de la asistencia al banquete funerario, tal y como establecían las leyes ${ }^{129}$. En la zona de Baztán no se menciona ni la colación ni la ordenanza de los reyes, sino que

123 Testamento de Miguel de Arbizu y Juana Sanz de Munárriz, vecinos de Munárriz, AGN, Protocolos Notariales, Salinas de Oro, Juan Miguel de Salinas, c. 2, s. c., año 1501.

124 ...e por goardar la inhibicion de los reyes nostros senniores esperamos e mandamos... que se dé a comer y a beber a todos los clérigos y escolares que acudan y a los parientes cercanos y cofradres de Riezu pan, vino, carne o pescado. Testamento de Juan Miguel de Iturgoyen y de su mujer María Périz de Iturgoyen, vecinos de Riezu, AGN, Protocolos Notariales, Salinas de Oro, Juan Miguel de Salinas, c. 2 , s. c., 25 de enero de 1501 .

${ }^{125}$ García Ibáñez de Echauri y Juana Martínez de Echauri, indican que se dé de comer y de beber a los clérigos, escolares y parientes, como es habitual en otros testamentos, pero también $e$ a cada dos personas mayores de cada casa de Echauri pan, vino, carne o pescado, según el día lo permitiese, además de la colación en la plaza, cumpliendo así la ordenanza de los reyes. AGN, Protocolos Notariales, Salinas de Oro, Juan de Salinas, c. 4, s. c., 17 de enero de 1510.

${ }^{126}$ AGN, Protocolos Notariales, Salinas de Oro, Juan Miguel de Salinas, c. 4, s. c., 20 de octubre de 1513. Testamento de Catalina de Elío, mujer de Juan Ibáñez de Goñi, vecina de Elío.

${ }^{127}$ AGN, Protocolos Notariales, Salinas de Oro, Juan Miguel de Salinas, c. 4, s. c., 28 de diciembre de 1513. Testamento de Rodrigo de Arazuri.

128 Item hordeno e mando que sea dado qonbivio el dia del enterrorio de mi dicho cuerpo a los religiosos, capellanes e parientes cerquanos en el grado segunt la bordenanza por tempo ha fecha e assentada en este Regno e a los fazederos del pan, candelas e taynedores de las campanas. AGN, Protocolos Notariales, Puente la Reina, Martín Brun, c. 1, n. 2, 28 de mayo de 1502. Testamento de Juan de Sarría, vecino de Puente.

129 Testamento de Gracia de Muruzábal, viuda de Martín de Leoz, vecina de Obanos, AGN, Protocolos Notariales, Puente la Reina, Martín Brun, c. 1, n. 3, 1 de octubre de 1500. 
se ofrecen comidas de forma general, a todos los asistentes al funeral ${ }^{130}$. Sin embargo, algunos otros testamentos sí especifican el tipo de invitados que cumplirían el grado legal permitido ${ }^{131}$. En la zona de Tudela son cuatro las referencias que se tienen a banquetes. En las tres primeras ${ }^{132}$ los testadores son miembros de la cofradía de San Dionís y en las comidas de funeral que encargan se invita a participar a sus hermanos cofrades ${ }^{133}$. La cuarta noticia es excepcional porque en ella aparece un banquete que podría denominarse «al modo legal», donde los protagonistas son los pobres y los religiosos, que se encargarían de rezar por el alma de la difunta durante toda la novena ${ }^{134}$.

Las viandas que se toman son muy similares a las que se disfrutan en otras zonas peninsulares ${ }^{135}$. En función del tiempo litúrgico y vigilias, carne o pescado, además de pan, vino y queso ${ }^{136}$, alimentos básicos en la dieta medieval, especialmente entre la gente más modesta ${ }^{137}$. En varios testamentos del valle de Baztán, una zona tradicionalmente dedicada al pastoreo y a la cría de ganado, se especifica el encargo de una vaca ${ }^{138}$. Otros testadores concretan el tipo

130 Banquete en entierro para los que acudan dando a comer a las gentes que vendran a las dictas bonrras (entierro, novena y cabo de año) segunt el tiempo mandara. Testamento de Graciana, viuda de Juan de Peru, vecina de Maya. AGN, Protocolos Notariales, Santesteban, [Juan de Ursúa], c. 1, s. c., 15 de diciembre de 1505 .

131 ...mando dar a comer en su enterrorio a los capellanes, parientes e amigos fasta una vaca con su expenssa o su montamiento. Y ...en la novena mando dar a comer a los capellanes y a los parientes e amigos que bien visto sera a sus cabeçaleros. Testamento de Machín de Oteiza, vecino de Oteiza, AGN, Protocolos Notariales, Santesteban, Martín de Ursúa, c. 1, n. 80, 10 de febrero de 1496. Testamento de Eneco Sañz, señor de Echeverri, AGN, Protocolos Notariales, Santesteban, c. 1, s. c., 26 de julio de 1513: dando a comer (en el entierro, novena y cabo de año) a los clerigos, pobres e parientes.

132 Testamento de Greva de Aibar, racionero de Santa María de Tudela, AGN, Protocolos Notariales, Tudela, Sancho Ezquerro, n. 29, 8 de enero de 1485. Testamento de Águeda Andrés, viuda y vecina de Tudela, AGN, Protocolos Notariales, Tudela, Juan Martínez Cavero, c. 5, f. 73, 8 de mayo de 1508. Testamento de Pedro de Falces, presbítero y beneficiado en la iglesia colegial de Santa María de Tudela, AGN, Protocolos Notariales, Tudela, Juan Martínez Cavero, c. 5, f. 97, año 1510.

133 Como en Zaragoza, ver BARRAQUÉ, J. P.: Saragosse à la fin du Moyen Âge, p. 304.

134 AGN, Protocolos Notariales, Tudela, Juan Martínez Cavero, c. 6, fajo 1512, f. 76v-78r, 27 de abril de 1512. Testamento de Juana de Calatayud, viuda de Martín de Mezquita, ciudadano de Tudela.

135 Cfr. López Carreira, A.: A cidade de Ourense no século XV. En dos testamentos de la ciudad de Orense se ofrecen: Item mando que leven comygo en oferta buun par de pescadas e des libras de pan trigo e buna cabaaça de viño e se for dia de carne que leven quatro mrs. de carne. Mariña da Vila, 14 de septiembre de 1434, doc. n. 9 del apéndice documental. O también: Item mando que leven comigo por ofertas medea vaca ou medeo boy e una carrega de vyño e dous sacos de pan trigo et se for dia de pescado outro tanto... Testamento de Arnao de Frisia, mercader vecino de Santiago, 17 de enero de 1489, doc. n. 22.

136 Testamento de Ramiro de Asiáin, escudero, vecino de Muniáin, AGN, Protocolos Notariales, Salinas de Oro, Juan Miguel de Salinas, c. 1, n. 2, año 1462.

137 En el entierro de Gracia de Arraztia, fallecida el 3 de mayo de 1512, se comen 10 robos de trigo, 28 libras 4 reales de carne y tocino, y 2 libras 13 reales de vino blanco y tinto. AGN, Protocolos Notariales, Puente la Reina, Martín Brun, c. 1, n. 2, 12 de mayo de 1512.

138 Testamento de Juan Sanz de Arroqui, zapatero vecino de Elizondo, en el que deja encargado dar a comer a los que verran sobre su cuerpo si el dia diere maten una vaca en el dia de su enterrorio e otra en el 
de pescado que se debería servir, siendo las sardinas el más usual ${ }^{139}$. En el entierro de Juan Sanz Ibáñez de Muez se come pan (se emplean 24 robos de trigo para elaborarlo), 40 carapitos de vino, una vaca y 6 ovejas. Y para su aniversario se dispone pan y queso y 3 becerros ${ }^{140}$. Catalina de Vidaurre es la única, entre las muestras encontradas, que encarga legumbres, por ser época de Cuaresma, además de los alimentos ya conocidos, como pan y vino ${ }^{141}$.

A falta de un análisis de los testamentos pertenecientes a otros fondos documentales navarros ${ }^{142}$, puede concluirse que el banquete funerario y su correspondiente colación parecen tener una arraigada presencia en las zonas rurales, al igual que ocurre en otros territorios peninsulares como La Rioja ${ }^{143}$, Castilla ${ }^{144}$ o Galicia ${ }^{145}$ o en algunas zonas de Francia, como Aviñón ${ }^{146}$. Pero en

dia de su nobena. AGN, Protocolos Notariales, Elizondo, 22 de octubre de 1512. También requiere una vaca para su banquete Machín de Oteiza, vecino de Oteiza, AGN, Protocolos Notariales, Santesteban, Martín de Ursúa, c. 1, n. 80, testamento de 10 de febrero de 1496.

139 Que den de comer y de beber a los clérigos, escolares, parientes y cofrades de Munárriz que acudan pan, vino, carne o pescado según el día requiriese $e$ a los otros que vinieran a los dichos nostros enterrorios den la colacion en la plaza con pan, vino, queso e sendas sardinas segunt la costumbre e inbibicion que esta puesta por sus magestades. Testamento de Miguel Miguélez de Munárriz y Catalina su mujer, vecinos de Munárriz, AGN, Protocolos Notariales, Salinas de Oro, Juan Miguel de Salinas, c. 2, s. c., 22 de junio de 1502. Un banquete, muy espectacular, es el que se ofrece en la novena y cabo de año de Juan de Aguirre, señor de Agorreta, en el que el pescado que se encarga es mucho más variado y exquisito, pero en el que tampoco faltan las humildes sardinas: 6 salmones y 300 arenques de la costa, 28 robos de trigo, merluza y sardinas, por las que se gastaron 2 sueldos, además de un sueldo de vino. AGN, Protocolos Notariales, Santesteban, c. 1, [año 1531].

${ }_{140}$ Nota de los gastos realizados por los cabezaleros de Juan Sanz Ibáñez de Muez, AGN, Protocolos Notariales, Salinas de Oro, Juan Miguel de Salinas, c. 2, s. c., 31 de agosto de 1496. Muy similar a la dieta navarra es la que recogen CANTERA MONTENEGRO, M.: «Religiosidad en la Rioja bajomedieval», pp. 122/ 130, en la zona riojana, o en el caso aragonés, RUBIO SEMPER, A.: «Piedad, honras fúnebres y legados», pp. 247/ 254, nota 46, GARCía. HeRrero, M. C.: «Ritos funerarios y preparación para Bien Morir», 109 y 110 y Rodrigo ESTEVAN, M. L.: Testamentos medievales aragoneses, p. 119. En ambas zonas se menciona el carnero como plato principal; en Calatayud, se incluye además el cordero. Esta dieta es asimismo semejante a la que ROYER DE CARDINAL, S.: Morir en España, pp. 180, 182 y 185 cita en la zona castellana, GómEZ NIETO, L.: Ritos funerarios, p. 67 para Madrid y en el territorio portugués CASTRO PINA, I.: «Ritos e imaginário da morte», p. 164.

1419 de marzo de 1512, AGN, Protocolos Notariales, Salinas de Oro, Martín Martínez de Vidaurre, c. 9, n. 5. ChiffoleaU, J.: La comptabilité de l'au-delà, p. 146, habla del consumo de garbanzos. MARANDET, M.-C.: Le souci de l'au-delà, p. 231, recoge la utilización de guisantes y de bacalao en la zona tolosana, como platos de Cuaresma. Por otra parte, en Barcelona, más que legumbres, se consumen verduras como espinacas o coles, además del consabido pescado. Cfr. EQUIP BROIDA: «Els àpats funeraris», p. 267.

142 Este es uno de los objetivos de la tesis «Requiem aeternam. Ritos, actitudes y espacios en torno a la muerte en la Navarra bajomedieval» que la doctoranda Julia Baldó Alcoz realiza en la actualidad.

143 Cantera Montenegro, M.: «Religiosidad en la Rioja bajomedieval», p. 130.

${ }_{144}$ ROYER DE CARDINAL, S.: Morir en España, por su parte, también recoge este fenómeno de la colación, pp. 181-182/ 186. Curiosamente, ni Carmen García Herrero, Agustín Rubio Semper, Jean Pierre Barraqué o $M^{a}$ Luz Rodrigo Estevan recogen colaciones en la zona aragonesa. Cabe pregun-

Hispania, LXV/1, núm. 219 (2005) 155-226 
las áreas urbanas las fórmulas de los convites funerarios se realizan de una manera más fraccionada. Así, el protagonismo de lá comida del entierro cobra un sentido diferente, pues la celebración del ágape se polariza entre diferentes instituciones religiosas a través de pitanzas, ligadas a las órdenes mendicantes, a los conventos urbanos y al clero de la ciudad. Todas estas manifestaciones circundan las estrictas leyes que restringen la celebración del banquete funerario y así los asistentes son atendidos limitando los dispendios económicos ${ }^{147}$. $\mathrm{Al}$ mismo tiempo, estos convites refuerzan los vínculos del grupo, familiares, vecinales, laborales y parroquiales y se procura conseguir con todo ello el recuerdo del difunto (memento morti) a través de las oraciones de todos los asistentes ${ }^{148}$. De tal modo, las comidas funerarias pasan de ser actos festivos y con marcado carácter pagano a símbolos de reunión espiritual y social donde se fomentan las virtudes de la caridad y de la piedad, tal y como pretendían las primeras normativas canónicas.

\subsection{Lugar de enterramiento}

\section{...dono el mi cuerpo a sepultura}

La elección del lugar donde los restos mortales van a reposar hasta la espera del Juicio Final era una cuestión sumamente importante para el hombre medieval. No sólo se ponía especial cuidado en designar la ubicación de la tumba, sino también a las personas con las cuales se deseaban acompañar en su sepultura, pues la muerte, como veremos, no separa a la familia, sino que, en muchas ocasiones, la reagrupa en torno a determinados espacios físicos tal y como sucedió en vida.

tarse sobre la mutua influencia de esta práctica ritual y legislativa y en qué territorio se daría en primer lugar, así como si en otras regiones de la península también se celebraban este tipo de refrigerios.

145 Testamento del mercader Arnao de Frisia, vecino de Santiago, de 17 de enero de 1489, doc. n. 22 del apéndice documental. Iten lles mando ao dito convento e flayres para sua pitança e colaçon por que eles me digan vegilia e misa con seus responsos como ban de costume, gento e ģinqoenta mrs. vellos. LÓPEZ CARREIRA, A.: A cidade de Ourense no século XV.

146 ChiffoleaU, J.: La comptabilité de l'au-delà, p. 144, donde menciona la práctica de colaciones entre diferentes cofradías de artesanos y agricultores.

147. Estas colaciones podrían ser muy similares a las caridades de las que hablan, entre otros autores, AleXandre-Bidon, D.: La Mort au Moyen Âge, p. 171 o Gómez Nieto, L.: Ritos funerarios, p. 67. Sin embargo, las colaciones navarras parece dotarse de una condición más amplia porque en ellas no sólo se ofrece comida a los pobres, sino que se invita a una mayor cantidad de personas de toda índole.

148 Guiance, A.: Los discursos sobre la muerte, p. 39, Rodrigo Estevan, M. L.: Testamentos medievales aragoneses, p. 117 y CHIFFOLEAU, J.: La comptabilité de l'au-delà, pp. 143/ 146-147. 
A finales del siglo XIV los enterramientos ya han invadido los templos, a pesar de que esta práctica está prohibida desde la Alta Edad Media ${ }^{149}$. Aunque, por abrumadora mayoría, siguen siendo muy numerosas las sepulturas en cemente$\operatorname{rios}^{150}$, como se va a ver enseguida. La inhumación de determinadas personas en el interior de los templos se había ido intensificando y, en estos momentos, se permite también a los laicos ${ }^{151}$, especialmente en las zonas urbanas. Muchas de ellas adquieren fosas simples, donde pueden reposar varios miembros de una familia. Otros, con más poder e influencia, se benefician de espacios más amplios, como lienzos de pared donde obrar sepulcros adosados o, incluso, capillas propias y en las que gozan de derecho de sepultura exclusivo ${ }^{152}$.

Los protocolos navarros indican que el cementerio es el espacio de inhumación más frecuentemente elegido, con un porcentaje aproximado del $55 \%$ de los testadores, la gran mayoría de ellos localizados en las áreas rurales ${ }^{153}$. Por contraposición a estos datos, 126 testamentos prefieren una zona del interior del templo, lo que suponen un $23 \%$ del total de testadores, la inmensa mayoría pertenecientes a la urbe tudelana ${ }^{154}$.

Una gran parte de los testadores de las zonas rurales, incluídos algunos personajes de la nobleza local y religiosos, eligen su sepultura en los cementerios de las iglesias parroquiales de su lugar de residencia, suponiendo un porcentaje total del $64 \%^{155}$. Tal es el caso de Juan Sanz de Munárriz y Leonor de Arguiñano que deciden ser inhumados en el cementerio de San Martín de Arguiña-

149 Concretamente desde el primer Concilio de Braga (año 561). Cfr. BANGo TORviso, Isidro: «El espacio para enterramientos privilegiados en la arquitectura medieval española» en Anuario del Departamento de Historia y Teoría del Arte (Madrid) (1992), p. 94.

150 Ibidem, p. 107.

151 Ibidem, pp. 113-114

152 RoDrigo EsteVAN, M. L.: Testamentos medievales aragoneses, pp. 80-81, describe el proceso evolutivo de enterramientos en interior de templos que sufrió la ciudad de Daroca en los siglos XIV y XV. Incluye, asimismo, algunas noticias sobre enterramientos excepcionales en el interior de iglesia.

153 Aparece citado en 197 documentos de forma explícita (36\%) y se supone en 108 casos. En el área rural circundante a la ciudad de Calatayud, la mayoría de los testadores también desean ser enterrados en cementerio, mientras que la mayor parte de los habitantes de la urbe lo hacen en el interior de monasterios o iglesias. Vid. RUBiO SEMPER, A.: "Piedad, honras fúnebres y legados», p. 243. Por el contrario, en los testamentos que maneja CANTERA MONTENEGRO, M.: «Religiosidad en la Rioja bajomedieval», p. 120, las personas que deciden ser sepultadas en cementerio son una minoría, a pesar de que la zona que examina es eminentemente rural.

${ }^{154}$ En Tudela, aproximadamente en 98 casos se eligen los interiores de iglesias como espacio de enterramiento, lo que equivaldría a un $25 \%$ de los testadores de esta ciudad. Cfr. García GuZMán, M. M., ABELLÁN PÉREZ, J.: La religiosidad popular de los jerezanos, pp. 70-71 y cuadro en 73 . Y ÁLVAREZ FORTES, A. M.: El sentit de la mort en l'Elx, p. 79, nota 185.

15s En 110 de 170 documentos del área rural, se escoge enterramiento en cementerio: Salinas de Oro, en 95 casos de 124 documentos (76\%); Santesteban 10 de 15 (66\%); Elizondo 3 de 3 (100\%). Sin embargo, en la notaría de Puente la Reina sólo 2 de 6 testadores (33\%) desean su inhumación en cementerio; uno de ellos, en la localidad de Guirguillano, donde reside. En el caso de Cascante 5 de 5 (100\%); Buñuel 1 de 1 (100\%), Fustiñana 11 de 12 (91\%), Cabanillas 2 de 4 (50\%). 
no ${ }^{156}$. Pascuala, viuda de Lope de Arbizu y vecina de Puente la Reina, quiere su sepelio en el de San Jaime ${ }^{157}$; Miguel de Berroeta, señor de la casa de Iriartea, en el cementerio de Santiago de Elizondo ${ }^{158}$, e Inés Cabeza, mujer de Ibáñez, en el de Santa María de Fustiñana ${ }^{159}$.

En Tudela, sobre un total de 379 , son 87 los que ordenan enterrarse en cementerio de forma explícita; en 108 documentos no se menciona de forma expresa, sino que se supone por el tipo de testador y de iglesia que se elige. Se estimaría pues, entre un $22 \%$ y un $51 \%$ el total de las personas que se entierran en cementerio en esta ciudad ${ }^{160}$. Algunos ejemplos son los que siguen: Juan Vicente Burnello quiere su sepelio en el cementerio de San Miguel ${ }^{161}$, Constanza Puyvert en el de San de Nicolás ${ }^{162}$, Elvira de Arnedo en el de San Salvador ${ }^{163}$ y Pedro de Lezcano en el de Santa María Magdalena ${ }^{164}$. En esta ciudad, además, se incorpora un nutrido grupo de personas que se entierran en los claustros de las principales iglesias ${ }^{165}$, como Santa María ${ }^{166}$ o San Francisco ${ }^{167}$.

Además, es significativo el número de los que se hacen sepelir en su propia parroquia, independientemente de si es zona exterior o interior. A partir de un pequeño muestreo realizado a través del cuaderno del notario Martín Garceiz Don Costal ${ }^{168}$ se concluye que un $36 \%$ de los testadores tudelanos eligen el enterramiento en su parroquia durante este período ${ }^{169}$. Muchos otros optan por

156 AGN, Protocolos Notariales, Salinas de Oro, Juan Miguel de Salinas, c. 2, 30 de septiembre de 1496.

157 AGN, Protocolos Notariales, Puente la Reina, Martín Brun, c. 1, n. 1, 23 de abril de 1491.

158 AGN, Protocolos Notariales, Elizondo, Juan de Elizondo, leg. 1, n. 53, 21 de septiembre de 1509. Pero Orh, señor de la casa de Aldaloit, en el cementerio de San Martín de Garzáin, en la fosa de su casa. AGN, Protocolos Notariales, Santesteban, Juan de Ursúa, c. 1, n. 68, 27 de enero de 1491.

159 AGN, Protocolos Notariales, Tudela, Juan de Cabanillas, c. 13, 7 de diciembre de 1506. Testamento de Inés Cabeza, mujer de Ibáñez.

160 Por el contrario, un 25\% escoge el interior de las iglesias. Así Tudela es la zona donde se producen porcentajes más elevados de enterramiento en interior, por contraposición a las zonas rurales, donde la mayoría de la población lo hace en el exterior.

161 AGN, Protocolos Notariales, Tudela, Martín Garceiz Don Costal, cuad. 1381-1383, f. 51-52, 26 de octubre de 1381.

162 Testamento de Constanza Puyvert, mujer de Peyre de Agorreta, bañero. AGN, Protocolos Notariales, Tudela, Martín Garceiz Don Costal, cuad. 1381-1383, f. 58, 7 de noviembre de 1381.

${ }_{163}$ Testamento de Elvira de Arnedo, vecina de Tudela, viuda de Juan de Asensio y casada en segundas nupcias con Juan de Navascués, AGN, Protocolos Notariales, Tudela, Bernart de Morlanes, c. 2, 9 de enero de 1460 .

164 AGN, Protocolos Notariales, Tudela, Sancho Ezquerro, n. 9, abril de 1482.

165 Un total de 26 testadores eligen el claustro como lugar de reposo de sus restos, suponiendo un $6 \%$ del total.

166 En 20 documentos, entre otros, en el testamento de Pedro de Garro, caballero y vecino de Tudela, AGN, Protocolos Notariales, Tudela, Miguel de Araiz, caj. 1, año 1430.

167 Concretamente aparece en 5 testamentos.

168 Este cuaderno comprende los años 1381 a 1383.

169 De un total de 47 documentos recopilados, en 17 ocasiones hay total coincidencia entre el lugar de habitación y la parroquia donde se eligen sepultura. Así lo hace, por ejemplo, García de

Hispania, LXV/1, núm. 219 (2005) 155-226 
iglesias distintas a sus parroquias debido a múltiples razones, como la devoción personal a un determinado santo, la pertenencia a una cofradía religiosa o gremial, el prestigio social o el deseo de yacer junto a un familiar enterrado en otro establecimiento religioso. Además, la influencia de la predicación es determinante para que el número de testadores que elijan a las órdenes mendicantes, como receptores de sus cuerpos ${ }^{170}$, y en concreto al monasterio de San Francisco de Tudela, sea cada vez más elevado, tal y como ocurre en otras urbes españolas ${ }^{171}$. El hecho de que algunos miembros de los más ilustres linajes de la nobleza de la ciudad que se entierran en la iglesia de San Francisco, que disfrutaba de gran prestigio en Tudela, como Íñigo de Ujué y Estefanía de las Navarras 172 o Juana de Agramont, mujer del señor de San Adrián, Sancho de Vergara ${ }^{173}$ avalan esta tesis. También algunos miembros de la pujante burguesía de la localidad: María de San Martín, viuda del honorable Juan Pérez Calvo, notario y secretario de Tudela ${ }^{174}$, Sancho de Añón, pregonero y vecino de Tudela ${ }^{175}$ o María López, viuda del licenciado Pedro de Navascués apotecario ${ }^{176}$.

Pese a todo, existe un número muy elevado de testamentos navarros, en torno a los cien, en los que no aparece definida la ubicación de la sepultura; la mayoría de ellos están recogidos en la urbe tudelana. Las razones por las que no se precisa de forma explícita pueden ser varias. Porque no aparece en el documento ${ }^{177}$, o

Aibar, habitante de la parroquia de San Nicolás que se entierra en el cementerio de San Nicolás, AGN, Protocolos Notariales, Tudela, Martín Garceiz Don Costal, cuad. 1381-1383, f. 115-116, 11 de agosto de 1382. La misma tendencia se confirma en Jerez, durante la primera mitad del siglo XIV, García Guzmán, M. M., Abellán Pérez, J.: La religiosidad popular de los jerezanos, p. 69. Frente a un 61\% que estima L. GómEZ NiETO para la villa de Madrid, Ritos funerarios, pp. 62-63.

170 En 84 testamentos (un 22\% de los documentos totales de esta localidad), de los cuales, 79 pertenecen a los siglos XV y XVI. El "boom franciscano» surge en Tudela hacia la década de los 70 del siglo XV. En la ciudad de Valladolid los franciscanos también sufren un desarrollo muy similar, alcanzando su cénit en la segunda mitad del siglo XV, con un porcentaje de enterramientos que ronda el $21 \%$, $c f r$. RUCQUOI, Adeline: "De la resignación al miedo: la muerte en Castilla en el siglo $\mathrm{XV}$ » en La idea y el sentimiento de la muerte en la Historia y en el Arte de la Edad Media, Santiago de Compostela, 1988, vol. 1, p. 56.

${ }_{171}$ En el caso de Calatayud es así, cfr. Rubio SEMPER, A.: «Piedad, honras fúnebres y legados», p. 243. En Zaragoza, los menores también gozan de gran predicamento, $c f r$. BARRAQUÉ, J. P.: Saragosse à la fin du Moyen Âge, p. 292. E igualmente en Daroca, cfr. Rodrigo Estevan, M. L.: Testamentos medievales aragoneses, p. 82, nota 70.

172 AGN, Protocolos Notariales, Tudela, Martín Garceiz Don Costal, cuad. 1381-1383, f. 252, 29 de octubre de 1383.

173 AGN, Protocolos Notariales, Tudela, Pedro de Latorre, c. 15, f. 26, 26 de marzo de 1505.

${ }_{174}$ AGN, Protocolos Notariales, Tudela, Juan Martínez Cavero, c. 6, fajo 1512, f. 147r., 16 de septiembre de 1512.

175 AGN, Protocolos Notariales, Tudela, Juan Martínez Cavero, c. 5, f. 776, año 1509.

176 AGN, Protocolos Notariales, Tudela, Pedro de Latorre, c. 14, cuad. 1493-93, f. 53v.-54v., 27 de diciembre de 1494.

177 Es el caso de Domingo de Muez y María de Goñi, vecinos de Goñi, que en su testamento de 18 de enero de 1493, no establecen ninguna manda de sepultura, aunque sí disponen sobre el día de 
porque deciden que sean sus cabezaleros o sus familiares los que elijan el lugar donde reposarán sus restos mortales. Así Martín de Arzoz, rector de Viguria, que desea que su cuerpo sea sepelido en la iglesia parroquial de San Román de Arzoz en la sepultura do mis cabezaleros acordaran con los vezinos del pueblo ${ }^{178}$.

Existen, además, otros testadores que emprenden viaje o peregrinación y que no saben si morirán en el camino ${ }^{179}$. Deciden así ser enterrados en el lugar donde les sorprenda la muerte, aunque algunos de ellos sí recogen el ritual a seguir durante su funeral o las misas que desean se recen por sus almas. Así lo dispone don Sancho Bitas, presbítero, antes de partir de viaje a Roma.

...estando en camino es para se partir para la corte romana temiendo morir en el camino o de que alla legado o quando a Dios le pluguiere queriendo preuenir al remedio de su anima et disponer de los bienes suyos... [establece testamento, en el que ordena:] Primeramente cada que a Dios le pluguiere ordenar de su anima, mando fer su cuerpo sepellido en la yglesia principal de la ciudad, villa o lugar donde la muerte le tomare et que alli le sea fecho su enterrorio como mejor se pudiere con la sustancia de los bienes que consigo tuuiere. Et luego que aca se supiere de cierto de su muerte, mando que le sea fecho su forma de enterrorio, nouena e cabo de novena, en la yglesia de Sancta Maria Magdalena de la dicta ciudat sobre la fuessa de sus parientes los de Bitas ${ }^{180}$.

Por otra parte, el interior de las iglesias está sujeto a una distribución jerárquica a partir de un punto central que es el altar mayor, núcleo topográfico y espiritual de la iglesia, lugar donde se realiza el Sacrificio eucarístico. Así el espacio del presbiterio y especialmente el comprendido entre el altar y el coro es el más codiciado. Junto a éste, comparten protagonismo las capillas de los ábsides que configuran la cabecera y las ubicadas en las naves laterales. Durante toda la Edad Media estas zonas estarán reservadas a los personajes destacados en el ámbito social y religioso. A partir del siglo XVI, cuando se generaliza definitivamente el enterramiento en el interior de la iglesia, se perseguirá un nuevo objetivo, la «democratización» de los enterramientos en el presbiterio ${ }^{181}$.

su entierro, novena, misas y limosnas. AGN, Protocolos Notariales, Salinas de Oro, Juan Miguel de Salinas, c. 2, n. 15 .

178 AGN, Protocolos Notariales, Salinas de Oro, Juan Miguel de Salinas, c. 4, s. c., 21 de noviembre de 1510. Testamento de Martín de Arzoz, rector de la iglesia parroquial de Viguria y vecino de Arzoz.

179 Testamento de Elvira de los Arcos. AGN, Protocolos Notariales, Tudela, Juan Aristoy y Navarro, c. 37, f. 162r-163v, 28 de abril de 1512. Según cita VALDIviELSO Ausín, Braulio: Aventura y muerte en el Camino de Santiago, Burgos, 1999, p. 21, el $65 \%$ de los peregrinos que emprendían rumbo a Santiago morían en el viaje o desaparecían. De hecho, considera que son más los romeros que fallecían durante el viaje de vuelta, $c f r$. p. 32.

180 AGN, Protocolos Notariales, Tudela, Juan Martínez Cavero, c. 4, f. 82v.-84r., 29 de Mayo de 1504.

${ }_{181}$ Cfr. BANGO TORVISO, I.: «El espacio para enterramientos privilegiados», p. 117. 
En unos casos el sitio elegido está en torno al altar mayor, como la tumba que solicita Diego Jiménez de Sozer, escudero del señor de Echarren en la iglesia de Santa Catalina de Echarren ${ }^{182}$. La zona comprendida entre el altar y el coro es también muy preciada, y allí tienen su sepultura Mateo Pérez de Miranda y Gracia Pérez de Ágreda, debajo de la grada de Santa María la Mayor ${ }^{183}$. O Íñigo de Ujué y Estefanía de las Navarras en San Francisco de Tudela: ...un solar de sepultura dentro en la dita yglesia logar (...) de iuso de la grada mas insana del altal mayor enta la partida del subdiacono dont se dize la epistola... ${ }^{184}$. En otros casos, se escogen altares menores dedicados a santos y localizados en capillas y en las naves laterales ${ }^{185}$, como lo indica Pedro Guerrero cabo el altar de Sant Anthon de Padua en aquella sepultura donde estan soterrados sus padre, madre $e$ otros parientes en San Francisco de Tudela ${ }^{186}$.

Otro espacio de gran trascendencia es el coro, ya que en él se celebran las horas canónicas de las iglesias más importantes y de las catedrales. Sin embargo, en algunos templos, especialmente en las pequeñas parroquias urbanas y en las rurales, el coro no se sitúa en la zona inmediatamente posterior a la cabecera, sino que, por el contrario, se halla ubicado en la zona de los pies del templo, sobre la puerta de entrada ${ }^{187}$. En uno y otro caso, tanto en su interior - si está situado en la nave central — como en su zona inferior — si se localiza a los pies del templose pueden hallar numerosos enterramientos. Así, se otorga a Lope Ibáñez de Salinas y Jordana de Magallón ...un solar de sepultura dentro en la dita yglesia (...) dentro en el coro en la entrada baxa en medio de iuso del pulpito dont suele oficiar la quoal dita sepultura... por su contribución a la edificación de la iglesia de San Francisco ${ }^{188}$.

Los lugares de paso como el crucero y las puertas son también áreas muy solicitadas, como queda demostrado por las 17 referencias que se han hallado. Los fieles y religiosos que caminaran por estas zonas pasarían sobre estas sepulturas, recordando a los difuntos que en ellas reposaban; de tal manera, fieles y clero contribuirían a la salud de los muertos no sólo a través de los oficios religiosos, sino también a través de su recuerdo articulado en plegarias por sus almas ${ }^{189}$.

182 AGN, Protocolos Notariales, Salinas de Oro, Juan Miguel de Salinas, c. 1, n. 31, 2 de julio de 1472.

183 AGN, Protocolos Notariales, Tudela, Pedro de Latorre, c. 4, 25 de marzo de 1492.

${ }^{184}$ AGN, Protocolos Notariales, Martín Garceiz Don Costal, cuad. 1381-1383, f. 252, 29 de octubre de 1383.

185 Polanco Melero, C.: Muerte y sociedad en Burgos, p. 293.

${ }_{186}$ AGN, Protocolos Notariales, Juan Martínez Cavero, c. 6, fajo 1512, f. 11v.-13r., 4 de enero de 1512.-Tudela. Pedro Guerrero, vecino de Tudela.

187 Polanco Melero, C.: Muerte y sociedad en Burgos, p. 295, define muy claramente la disposición de estos coros altos así como la distribución de las sepulturas que bajo él se emplazan.

188 AGN, Protocolos Notariales, 'Tudela, Martín Garceiz Don Costal, cuad. 1381-1383, f. 251, 29 de octubre de 1383. Concesión de sepultura a Lope Ibáñez de Salinas y a su mujer Jordana de Magallón, vecinos de Tudela.

189 Álvarez Fortes, A. M.: El sentit de la mort en l'Elx, p. 77, nota 180. Esta autora, siguiendo la teoría de Michel Vovelle, cree que estas zonas de paso poseeerían además un contenido simbólico de humildad y modestia, ya que las tumbas que en ellas se situaban, serían pisadas por los que transitasen por este espacio. 
El crucero, además, cuenta con una doble ventaja. Por un lado, se ubica muy próximo al altar mayor y a los altares situados en los ábsides de la cabece$\mathrm{ra}$, donde era usual que se hubiesen fundado capillas de personalidades ilustres ${ }^{190}$ y por otro, es una zona de paso. Ahí se localiza la tumba de Juliana de Saron, viuda de Martín de Rada ...que es en el crucero delante del sennyor Sant Babil en Santa María de Tudela ${ }^{191}$. Y la de Martín de Alegría, en la parte entrando por la puerta del portal, junto a la sepultura de don Jimeno de Milagro, a mano ezquerra están las gradas del altar de Santa Maria y a los pies de ella se puede sepelir ${ }^{192}$.

Algunos testadores optan por las puertas de acceso al claustro como María Delgada, viuda, que desea reposar en la sepultura de su hija que esta cabo la puerta del deanado en la claustra de aquella junto a los gradones que descienden a la claustra de la dicha puerta de Santa María de Tudela ${ }^{193}$. Y otras tumbas se situarían en las puertas de ingreso a las capillas, como lo decide Martín de la Paz, ... a la entrada, de cara a la capilla de San Gil propiedad de mosén Pierres de Peralta debaxo de las gradas en lo plano de la iglesia de cara de la puerta de la dicha capilla sita en la iglesia colegial de Santa María de Tudela ${ }^{194}$.

La jerarquización del interior del templo también afecta a las naves: la central es la que goza de mayor relevancia, seguida por la nave del Evangelio y la de la Epístola ${ }^{195}$. De tal forma Juan de Logroño dispone el sepelio de su cuerpo en la sepultura que tiene en San Francisco de Tudela: ...la qual esta dentro en la navada del dicto monesterio de cara de la capilla de Sancta Maria del Pilar ${ }^{196}$.

En las diversas regiones peninsulares los testadores deciden ser enterrados en espacios tales como debajo de púlpitos de predicación, pilas de bautismo, pilas de agua bendita, cerca de figuras de santos o de ventanas ${ }^{197}$. De este modo, la cerca-

190 Así la capilla de San Gil, actualmente de la Esperanza, propiedad del canciller Villaespesa, donde ubica su precioso sepulcro en el que son inhumados él y su mujer, se halla en la cabecera de la catedral de Tudela. En ella ordena la colocación de un retablo dedicado a Nuestra Señora de la Esperanza y la celebración de una capellanía. Cfr. YARZA LUACES, Joaquín: "La capilla funeraria hispana en torno a 1400» en La idea y el sentimiento de la muerte en la bistoria y en el arte de la Edad Media, Santiago de Compostela, 1988, vol. 1, pp. 67-91.

${ }_{191}$ AGN, Protocolos Notariales, Tudela, Juan Martínez Cavero, c. 4, f. 42r.-43v., 29 de abril de 1500.

192 AGN, Protocolos Notariales, Tudela, Juan Martínez Cavero, c. 4, f. 110- 110r-v., 21 de mayo de 1505. Testamento de Martín de Alegría, viudo de Juana de Legarda y secretario de los reyes.

193 AGN, Protocolos Notariales, Tudela, Juan Martínez Cavero, c. 5, f. 109, 6 de junio de 1511.

194 AGN, Protocolos Notariales, Tudela, Juan Martínez Cavero, c. 4, f. 20r-24v., 15 de octubre de 1498. Martín de la Paz, vicario de Santa María Magdalena de Ablitas y beneficiado de Santa María de Tudela.

195 Polanco Melero, C.: Muerte y sociedad en Burgos, p. 293.

196 AGN, Protocolos Notariales, Tudela, Juan Martínez Cavero, c. 5, f. 131, 25 de septiembre de 1509. Juan de Logroño, vecino de Tudela.

197 Cfr. RODRIGo ESTEVAN, M. L.: Testamentos medievales aragoneses, pp. 89-92. CANTERA MONTENEGRO, M.: «Religiosidad en la Rioja bajomedieval», p. 120. RUBIO SEMPER, A.: «Piedad, honras fúnebres y legados», pp. 243-244. POLANCO MELero, C.: Muerte y sociedad en Burgos, pp. 292-294. GóMEZ NieTo, L.: Ritos funerarios, pp. 65-66. GARCía GuZMÁN, M. M., ABELLÁN PÉREZ, J.: La religiosidad popular de los jerezanos, pp. 71-72. ÁlvAREZ FORTES, A. M.: El sentit de la mort en l'Elx, pp. 
nía a la pila de agua bendita podía compensar su situación al fondo del templo, ya que cuando los fieles se santiguaban al acceder al templo, algunas gotas podían caer sobre la losa, beneficiando el alma del difunto gracias a su simbolismo purificador $^{198}$. En Navarra, también se encuentran este tipo de testimonios, aunque en menor medida. Juan de Estella, vecino de Tudela, casado con Estefanía de Lisan$\mathrm{ca}$, ordena su sepultura dentro en la dicta yglesia de Sancta Maria cabo la pila que esta de cara de Sant Johan Babtista junto con los bancos ${ }^{199}$. Claros ejemplos de devoción hacia santos y de fe en su poder intercesor se encuentran en estas noticias: Juana de Estorga, mujer de Juan de Logroño, dispone su enterramiento en el monasterio de San Francisco de Tudela delante del retablo de San Buenaventura ${ }^{200}$ y Juan de Guembe, rector de Guembe, localiza su tumba dentro de la iglesia de San Bartolomé de Guembe, delante de la figura de Santa Bárbara ${ }^{201}$.

Otros personajes de las jerarquías urbanas, eligen sepultura en capillas edificadas por ellos mismos o por sus familiares donde gozan de una posición privilegiada con respecto a los demás difuntos enterrados en la iglesia, pues en ella sus almas reciben oficios religiosos específicos que encargan celebrar en capellanías privadas ${ }^{202}$. En Tudela aparecen 39 noticias referentes a sepulturas en capillas o en sus proximidades, tanto de tipo familiar como comunal; en este caso podían ser propiedad tanto de una comunidad religiosa como de una cofradía.

La práctica totalidad de las capillas que aparecen mencionadas en la documentación de protocolos están localizadas en la ciudad de Tudela. En la parroquia-catedral de Santa María, son muy abundantes las menciones a la de Santa Catalina $^{203}$, San Gili204, Santa María ${ }^{205}$, San Lázaro ${ }^{206}$, San Eloy ${ }^{207}$, San Leonar-

79-80. También en Francia existen este tipo de referencias, ver, por ejemplo, CHIFFOLEAU, J.: La comptabilité de l'au-delà, pp. 168-170. AleXANDre-BIDON, D.: La Mort au Moyen Âge, p. 154, o en Portugal CASTro PINA, I.: Ritos e imaginário da morte, pp. 157-158.

198 Polanco Melero, C.: Muerte y sociedad en Burgos, p. 293.

199 AGN, Protocolos Notariales, Tudela, Juan Martínez Cavero, c. 6, fajo 1512, f. 124v.-125r., 26 de julio de 1512 .

200 AGN, Protocolos Notariales, Tudela, Juan Martínez Cavero, f. 43, 8 de septiembre de 1491.

201 AGN, Protocolos Notariales, Salinas de Oro, Juan Miguel de Salinas, c. 4, 11 de septiembre de 1511.

${ }^{202}$ Como en la capilla de los Egüés, don Pedro de Egüés, ordena la fundación de una capellanía y una serie de oficios religiosos. AGN, Protocolos Notariales, Tudela, Juan Martínez Cavero, c. 6, fajo 1512, f. 120 r.-v., año 1512. E ibidem, c. 6, fajo 1512, f. 60r.-62v, 17 de abril de 1512, fundación de capellanía.

${ }^{203}$ AGN, Protocolos Notariales, Tudela, Martín Garceiz Don Costal, cuad. 1381-1383, f. 110 113,8 de agosto de 1382. Testamento de Gutier García de Aguilar, vecino de Tudela, casado con Sancha Martínez de la Gaviella.

${ }^{204}$ AGN, Protocolos Notariales, Tudela, Juan Martínez Cavero, c. 4, f. 20r-24v., 15 de octubre de 1498. Testamento de Martín de la Paz, vicario de Santa María Magdalena de Ablitas y beneficiado de Santa María de Tudela.

${ }^{205}$ AGN, Protocolos Notariales, Tudela, c. 1, año 1448. Testamento de Tomás de San Martín, canónigo de Santa María de Tudela.

206 AGN, Protocolos Notariales, Tudela, Marcial Garceiz Don Costal, c. 1, 20 de marzo de 1444. Testamento de Diego de Vitoria y Juana López, su mujer.

${ }_{207}$ Testamento de Romea Jiménez de Bariellas, viuda, vecina de Tudela. Viuda de Pere Íñiguez de Ujué y viuda también de Ponz de Eslava. AGN, Protocolos Notariales, Tudela, Martín Garceiz 
do $^{208}$, San Juan Bautista ${ }^{209}$, San Juan Evangelista ${ }^{210}$, San Sebastián ${ }^{211}$, San Martín $^{212}$ y San Babil213. Además, aparece citada una capilla junto al campanario ${ }^{214}$ de la que no se dan más datos. En la iglesia parroquial de Santa María Magdalena, únicamente se hace referencia a la capilla de San Eloy, situada en el claustro $^{215}$. En el monasterio de San Francisco, se documentan dos, la capilla de Santa María de La Peña ${ }^{216}$ y la de San Pedro y San Pablo ${ }^{217}$. Y en la localidad de Estella, la capilla de Santa María en la iglesia de San Pedro ${ }^{218}$.

Los testadores que no tienen derecho a ser enterrados en una capilla familiar, eligen su sepultura en el exterior de la misma, ante la reja de entrada o bien en sus alrededores, como ya se ha visto en algún ejemplo. Estas personas, posiblemente movidas por la devoción al santo patrono de la capilla buscarían la piedad del mismo y la mediación por sus almas. Así María Sánchez de Añorbe, viuda de Alfonso de Valladolid, pide ser sepelida ante la capilla de San Leonardo de Santa María la Mayor de Tudela ${ }^{219}$. Lope de Iribarri y Catalina de Egüés, vecinos de Tudela, escogen

Don Costal, cuad. 1381-1383, f. 192-196, 4 de agosto de 1383. Testamento de Pascual de Magallón, canónigo de la iglesia colegial de Santa María de Tudela, AGN, Protocolos Notariales, Tudela, Juan Martínez Cavero, c. 5., f. 201, 16 de noviembre de 1508.

${ }^{208}$ AGN, Protocolos Notariales, Tudela, c. 1, año 1447. Testamento de María Sánchẹz de Añorbe, viuda de Alfonso de Valladolid, habitante de Tudela.

${ }^{209}$ AGN, Protocolos Notariales, Tudela, Juan Martínez Cavero, c. 6, fajo 1512, f. 2v.-3r., 23 de enero de 1512. Testamento de Pedro de Roncal, escudero.

${ }^{210}$ AGN, Protocolos Notariales, Tudela, Juan Martínez Cavero, c. 6, fajo 1512, f. 4r.-4v., 23 de enero de 1512. Concesión de sepultura a Felipe de Baigorri y sus descendientes.

211 Testamento de Estefanía de Veraiz, mujer de Miguel de Guergueráin, vecina de Tudela, AGN, Protocolos Notariales, Tudela, Martín Garceiz Don Costal, cuad. 1381-1383, f. 271-273, 29 de noviembre de 1383. Testamento de Pascual de Magallón, AGN, Protocolos Notariales, Tudela, Juan Martínez Cavero, c. 4, f. 226r.-234r., 20 de octubre de 1505.

212 AGN, Protocolos Notariales, Tudela, c. 1, 16 de marzo de 1436. Testamento de Gracia Renalt, viuda de Gaspar de Santa Cruz, vecina de Tudela.

${ }^{213}$ AGN, Protocolos Notariales, Tudela, Juan Martínez Cavero, c. 4, f. 234v.-235r., 22 de octubre de 1505 . Testamento de maestre Benedict y su mujer. Piden ser enterrados cerca de la capilla de San Babil.

${ }^{214}$ AGN, Protocolos Notariales, Tudela, Juan Martínez Cavero, c. 4, f. 35r.-37r., 28 de abril de 1506. Testamento de María Miguélez, mujer de Pedro Miguel Garcés.

${ }^{215}$ AGN, Protocolos Notariales, Tudela, c. 1, año 1437. Testamento de Gracia de Azagra, vecina de Tudela

216 Testamento de Donosa de Antillón, viuda de Pedro de la Cambra, AGN, Protocolos Notariales, Tudela, Juan Martínez Cavero, c. 4, f. 174r.-175v., 28 de octubre de 1504. Testamento de Catalina Felices, mujer de Alonso Burdem, vecino de Tudela, AGN, Protocolos Notariales, Tudela, Juan Martínez Cavero, c. 5, f. 137, 11 de septiembre de 1508.

${ }^{217}$ AGN, Protocolos Notariales, Tudela, Pedro de Latorre, c. 14, f. 166r.-167r., 20 de enero de 1496. Testamento de Francisco de Ágreda.

${ }^{218}$ AGN, Protocolos Notariales, Tudela, Sancho Ezquerro, n. 37, 24 de septiembre de 1482. Testamento de Inés de Lacarra, habitante de Tudela.

${ }^{219}$ AGN, Protocolos Notariales, Tudela, c. 1, año 1447.

Hispania, LXV/1, núm. 219 (2005) 155-226 
...una sepultura dentro del cuerpo de la dicta yglesia de Sancta Maria de cara a la capilla de Sant Johan Babtista cerca de los bancos de fusta afront a la mano derecha con sepultura de Maria de Caxaffort et a la ezquierda con sepultura de Johan de Murillo...220.

Las capillas más importantes y espectaculares, para Tudela, son las que pertenecen a las familias más distinguidas o al cabildo de la catedral y ocupan espacios privilegiados del edificio tanto en el ámbito espiritual como en el físico. Son elegidas como lugar de reposo porque son propiedad de un linaje a lo largo de generaciones y configuran un panteón completo donde están inhumados todos los antepasados del difunto. Además, esta agrupación en un espacio monumentalizado contribuiría a ensalzar el honor y la fama familiar a lo largo de generaciones $^{221}$. Los ejemplos más representativos son dos, la capilla de los Veraiz, en San Francisco y la de los Egüés, en Santa María la Mayor de Tudela. Así, doña María de Veraiz, viuda de Alonso de Guadalajara, escudero y caballerizo del rey Juan de Aragón, pertenece a una de las familias de mayor abolengo en la ciudad de Tudela y pide ser sepelida en la iglesia de San Francisco, en la sepultura de sus padres en la capilla de la Piedad del claustro, propiedad del linaje de los Veraiz ${ }^{222}$.

Y por otra parte, la capilla de los Egüés, sita en la iglesia de Santa María de Tudela, fue panteón de esta ilustre estirpe durante generaciones. Sin embargo, la unidad no se ciñe sólo a los lazos de sangre, sino que se amplía a sus servidores:

Los dichos senniores dan de gracia spiritual una sepultura dentro en la iglèsia devant la dicta capilla de Martin de Gues a Pedro de Salanueva e Maria de Gues su muger e a los descendientes dellos e para qualesquiere otros criados e criadas del dicto don Pedro de Gues que en ella quisieren ser sepelidos 223 .

220 AGN, Protocolos Notariales, Tudela, Juan Martínez Cavero, c. 6, fajo 1512, f. 64v.-65r., 17 de abril de 1512 .

${ }_{221}$ Sobre este asunto, conviene ver la monografía editada por VALDEZ DEL ÁlAMO, Elizabeth, Pendergast, Carol Stamatis (eds.): Memory and the Medieval Tomb, Aldershot, 2000, en la que se recogen diferentes estudios sobre la función de las sepulturas como elemento de recuerdo de los méritos y honor del fallecido, así como de estímulo para orar por su alma. Así es indicado en su introducción, pp. 1-15.

222 AGN, Protocolos Notariales, Tudela, Juan Martínez Cavero, c. 6, fajo 1512, f. 11r.-117v., 26 de junio de 1512.

223 AGN, Protocolos Notariales, Tudela, Juan Martínez Cavero, c. 6, fajo 1512, f. 120v., año 1512. Esta capilla pertenecía a la familia Egüés, aunque en ella fueron también enterrados servidores y criados, como lo manifiesta la siguiente donación de sepultura: Don Pedro de Egüés permite a Pedro de Salanueva y María de Egüés, su mujer, vecinos de Tudela y criados de don Pedro, a sus descendientes en recta línea, así como para otros criados y criadas que en ella se quisiere soterrar de una sepultura de cara e junto a la puerta de la capilla de los Egïés debaxo de la Invocación de la Transfiguración. En la quoal les dieron facultat para que ellos y sus succesores de recta linea descendientes se puedan soterrar. AGN, Protocolos Notariales, Tudela, Juan Martínez Cavero, c. 6, fajo 1512, f. 62v.-63r., 17 de abril de 1512. 
Asimismo, otras familias que adquieren pujanza durante estos siglos, erigen nuevas capillas. Como Juana Cirach, viuda, que desea ser sepelida en el monasterio de San Francisco, concretamente en una capilla que ha hecho construir para que sean inhumados en ella todos sus parientes. Es muy.interesante ver la disposición con que los cuerpos serán colocados en ella, ya que, hasta que se produzca la muerte de su hermano, reverendo maestre Cirach, los cadáveres deberían ser depositados en las tumbas bajas ${ }^{224}$.

Estos lugares, especialmente los pertenecientes a un linaje, estaban acompañados de retablos y pinturas, esculturas de santos, tapices y orfebrería, entre otras piezas decorativas. Las tumbas y sepulcros también constituían por sí mismos un elemento artístico sobresaliente. A pesar de ello, las noticias que tenemos sobre la composición de las capillas no abundan, ni tampoco las descripciones de tumbas, aunque sí contamos con algunos encargos de retablos ${ }^{225}$. Como el que ordena realizar Pedro Lorenz, casado con María Martínez Cajal, y que hará colocar sobre su tumba:

Item destinando ordeno et dono el mi cuerpo a sepultura a saber es en la iglesia mayor de Santa Maria de la ciudat de Tudela a saber es en el carnerario que esta de iuso de la tomba do esta sepelida Gracia Renalt qui fue. Et ruego et pido merce a los mis cabeçaleros de iuso escriptos que el mi cuerpo fagan sepelir honestament con de los dichos mis bienes segunt que a mi estado fazer pertenesçe. Item destinando hordeno et mando que enpues dias mios sia fecho vn retablo de las ymagines et figuras de seynnor Sant Pedro et de seynnor Sant Lorenz de espensa de XX florines el qual sera puesto sobre la dicha tomba a honor et reuerencia de los dichos santos por tal que ellos sean rogadores a nuestro seynnor Dios por mi anima 226 .

Hay sepulcros exentos de piedra ...en la sepultura grande de piedra ${ }^{227}$ y sepulcros de tipo arcosolio ... acerca de la paret principal dont es una grant toba ${ }^{228}$. Aunque estas noticias son minoritarias. Las referencias más abundantes son de

${ }^{224}$ AGN, Protocolos Notariales, Tudela, Juan Martínez Cavero, c. 4, f. 134v.-137v., 29 de junio de 1505 .

225 Cfr. MARTínez De AGUiRRe, Javier: «Retablos góticos navarros sólo conocidos por documentación» en $V$ Congreso de Historia de Navarra, 10-12 septiembre de 2002, Pamplona, (Pamplona) 2002, vol. 2, pp. 113-129/123-125.

226 AGN, Protocolos Notariales, Tudela, c. 1, 27 de junio de 1439.

${ }^{227}$ AGN, Protocolos Notariales, Puente la Reina, Martín Brun, c. 1, n. 1, 23 de abril de 1491. Testamento de Pascuala, viuda de Lope de Arbizu, vecina de Puente la Reina. Sepultura localizada en el cementerio de San Jaime.

${ }_{228}$ AGN, Protocolos Notariales, Tudela, Marcial Garceiz Don Costal, c. 1, 20 de marzo de 1444. Fundación de aniversario por Diego de Vitoria y Juana López, su mujer; sepultura localizada en la capilla de San Lázaro de Santa María de Tudela. CANTERA MONTEnEGro, M.: «Religiosidad en la Rioja bajomedieval», p. 124, también recoge noticias sobre sepulcros de pared. Y noticias muy detalladas de sepulcros en la investigación de CASTRO PINA, I.: «Ritos e imaginário da morte», pp. 159-160, incluidas referencias a sepulcros de arcosolio.

Hispania, LXV/1, núm. 219 (2005) 155-226 
tumbas $^{229}$, fosas ${ }^{230}$ y sepulturas ${ }^{231}$. La mayor parte de los testadores habla de fosa, excavada en el suelo, porque este modelo es el más abundante, asequible a todos los bolsillos y fácil de realizar, además de permitir una mejor distribución y aprovechamiento del espacio. Las referencias a fosa (fosa, fuesa, fuessa), curiosamente, son más abundantes en el medio rural. En el urbano es más habitual que se mencione la palabra sepultura, aunque esto no parece demostrar que el formato varíe sustancialmente.

En algunos testamentos de la ciudad de Tudela aparece citada la palabra carnerario $^{232}$ y parece constituir otro tipo de sepultura diferente a las anteriores ${ }^{233}$. Los testimonios documentales recogidos nos indican que estas tumbas pueden estar situadas tanto en cementerio como en claustro o interior de iglesia ${ }^{234}$ y coinciden así en ubicación con los que se han podido encontrar en otras zonas peninsulares como Aragón y Cataluña ${ }^{235}$. Parece que son sepulturas construídas en piedra y que

229 Testamento de Gracia Sanchiz de Olite, mujer de Sancho Beylla, vecina de Tudela, AGN, Protocolos Notariales, Tudela, Martín Garceiz Don Costal, cuad. 1381-1383, f. 61, 20 de noviembre de 1381.

${ }_{230}$ Testamento de Martín Iñiguez de Iturgoyen y Toda López, vecinos de Iturgoyen. AGN, Protocolos Notariales, Salinas de Oro, Juan Miguel de Salinas, c 1, n. 8, año 1471. Testamento de García de Corella, AGN, Protocolos Notariales, Tudela, Juan Pérez del Calvo, c. 9, n. 1, f. 45, 5 de mayo de 1477. CANTERA MONTENEGRO, M.: «Religiosidad en la Rioja bajomedieval», p. 123, también cita las fosas como las sepulturas más frecuentes.

${ }^{231}$ Fernando de Nirena, vecino de Tudela, AGN, Protocolos Notariales, Tudela, Juan Martínez Cavero, f. 36, 24 de noviembre de 1491. Martín de Resa y Elvira de Oco, AGN, Protocolos Notariales, Tudela, Juan Martínez Cavero, c. 4, f. 138r.- 141v., 29 de junio de 1505.

232 El Diccionario de la RAE entiende por carnerario, tal y como aparece denominado en los testamentos; el lugar donde se echan los cadáveres. Esta palabra derivaría directamente de la forma latina carnarium, fosa. Ambas palabras nos remiten a la actual palabra española, carnero, que es definida de las siguientes maneras: 1 . Lugar donde se echan los cadáveres. 2. Osario. 3. Sepulcro de familia que solía haber en algunas iglesias, elevado como una vara del suelo.

${ }^{233}$ MARANDET menciona otras tipologías de sepulturas como cisterna, monumentum, tumulus, bazio o vas, y que identifica con diferentes variantes de sepulturas, aunque ninguna de ellas se corresponde con el carnero del que se habla en los testamentos navarros. Cfr. MARANDET, M.-C.: Le souci de l'au-delà, pp. 158-159. Por tanto, es más que probable que coexistieran diferentes variantes de tumbas, entre las que me atrevo a señalar los carneros. De tal manera, bazio o vas (vaso) se referiría al sepulcro subterráneo en bóveda, o bien a un sarcófago de piedra o de mármol mientras que cisterna, monumentum y tumulus son tumbas, que pueden cubrirse bien con tierra amontonada (y señaladas con una cruz de madera, más propias de los cementerios y de difuntos de condición modesta) o con piedra. Íbid., p. 158. También CASTRO PINA, I.: «Ritos e imaginário da morte», 158-160, documenta diferentes tipos de sepulturas: covas equivalentes a fosas; monumentos, que serían nuestros sepulcros; y campas, que se identificarían con nuestras laudas sepulcrales.

${ }^{234}$ De 10 carneros mencionados en Tudela, 4 están situados en cementerio, 1 en claustro y los 5 restantes en interior de iglesia.

235 Rodrigo Estevan, M. L.: Testamentos medievales aragoneses, incluye algunos ejemplos de este peculiar modelo de sepultura, que se sitúan no sólo en cementerio sino también en interior de iglesia y en claustro; ver p. 81-97. A su vez define el carnero como «osario familiar en el cementerio parroquial o conventual», cfr. p. 86. Por su parte, RUBIO SEMPER, A.: «Piedad, honras fúnebres y legados»,p. 244, nota 9, recoge una noticia de un carnero perteneciente a la cofradía de la Trans- 
pueden albergar diferentes cuerpos, generalmente pertenecientes a una misma familia. Así lo demuestra el testamento de García de Carcastillo, vecino de Tudela:

destinando ordeno et dono mi cuerpo a sepultura a saber es en el cemiterio de la iglesia de Santa Maria Magdalena en aquell carnerario dont yaze sepelido Garcia de Carcastiello mi padre e otros de mi generacion...236

O estas líneas pertenecientes a una donación perpetua de una sepulturacarnero en Santa María de Tudela a Lope de Iribarri, barbero, y Catalina de Egüés, vecinos de Tudela:

...et que todos los fieles cristianos dessean haver receptaculo e habitacion en la sancta madre yglesia porque sus animas por sacrifficios e oraciones pueden haver salvacion por ende queriendo serles gratos y agrasdecidos inclinados a sus rogaria y peticion les fizieron gracia y donacion a perpetuo de una sepultura dentro del cuerpo de la dicta yglesia de Sancta Maria de cara a la capilla de Sant Johan Babtista cerca de los bancos de fusta afront a la mano derecha con sepultura de Maria de Caxaffort et a la ezquierda con sepultura de Johan de Murillo para que en ella los dictos conyuges puedan si quieren obrar carnerario et sepellirse ellos y sus fijos y descendientes dellos en recta linea ${ }^{237}$.

Los datos arqueológicos confirman esta teoría ${ }^{238}$. Los carneros son sepulturas construidas de obra, excavadas en el suelo, y con una amplitud y una profundidad mayor que las fosas tradicionales. Están cerrados mediante grandes losas en su parte superior y su acceso a la zona inferior se realiza por una escalera de piedra. Se ajustan, por consiguiente, a una tipología de sepultura colectiva, de carácter eminentemente familiar ${ }^{239}$, como afirma igualmente Carlos Polanco Melero para la ciudad de Burgos, tomando fuentes documentales de tipo arqueológico ${ }^{240}$.

fixio. Asimismo, en la zona catalana, concretamente en la ciudad de Barcelona, el investigador Jaume CASAMITJANA (Universidad de Navarra) ha encontrado este tipo de sepulturas, situadas, al igual que en Tudela y en Daroca en estos mismos tres espacios.

${ }^{236}$ AGN, Protocolos Notariales, Tudela, Marcial Garceiz Don Costal, c. 1, testamento de 24 de diciembre de 1436.

${ }^{237}$ AGN, Protocolos Notariales, Tudela, Juan Martínez Cavero, c. 6, fajo 1512, f. 64v.-65r. 17 de abril de 1512 .

238 Nuestro agradecimiento a Inés TABAR, directora de las excavaciones arqueológicas de la catedral de Tudela y al arqueólogo Jesús SESMA que nos permitieron observar in situ el interior de uno de estos carneros, hallado durante el transcurso de las obras que se realizan en dicho edificio.

239 ARIÈs, por su parte, y tras él otros muchos autores, identificaba los carneros o charniers como osarios donde los huesos se superponen de manera confusa y sin ningún tipo de relación. Cfr. $\mathrm{Ph}$. ARIÈs, El hombre ante la muerte, p. 53. Cita el caso concreto de los charniers situados en los claustros del antiguo Cementerio de los Inocentes de París. Siguen esta teoría, Rodrigo Estevan, M. L.: Testamentos medievales aragoneses, p. 86 y MARANDET, M.-C.: Le souci de l'au-delà, p. 144.

240 Polanco Melero, C.: Muerte y sociedad en Burgos, pp. 186-187, dice «En efecto, el carnero era una pequeña cripta subterránea abovedada, a la que se accedía por una escalera, cuya misión era 
Por otra parte, existen fosas comunes donde se entierra a los clérigos ${ }^{241}$, ubicadas en las cercanías del altar ${ }^{242}$, las puertas de entrada ${ }^{243}$ o el $\operatorname{coro}^{244}$. Sin embargo, no todos los religiosos desean que su inhumación sea hecha con sus compañeros, sino que algunos eligen su reposo junto a familiares ${ }^{245}$.

De igual manera, las cofradías poseen capillas o también fosas comunes donde dar inhumación a los cuerpos de sus hermanos cofrades si estos lo desean ${ }^{246}$.

El hombre medieval, como se ha visto en los apartados anteriores, no muere en soledad. Sus restos mortales tampoco reposan en soledad, sino que se hacen acompañar de otros seres queridos. La mayor parte de los testadores elige ser inhumado con familiares muy próximos que ya han fallecido y, además, en muchas ocasiones, deja determinado quienes serán los que se unirán a ellos en años futuros.

De los matrimonios que conceden testamento de hermandad o que adquieren una sepultura a título común, un $70 \%$ desean ser enterrados en la misma

recibir los cuerpos de los difuntos de una misma familia o linaje. Aquí no se echa tierra, sino que los restos se depositan uno junto a otro, compartiendo un espacio común, cerrado mediante una losa».

${ }^{241}$ Como Juan de Echauri, capellán y vecino de Echauri, que, tanto en su testamento como en su codicilo, elige la sepultura de los vicarios y clérigos en San Esteban de Echauri. AGN, Protocolos Notariales, Salinas de Oro, Juan Miguel de Salinas, c. 4, testamento de 18 de enero de 1511.

${ }^{242}$ Borrador y testamento de Fernando de Vidaurre, capellán y beneficiado de Santa Catalina de Vidaurre, donde este testador decide su sepultura en Santa Catalina de Vidaurre, delante del altar mayor, en la fosa de los beneficiados, AGN, Protocolos Notariales, Salinas de Oro, Juan Miguel de Salinas, c. 2, 90-91, 8 de marzo de 1497.

${ }_{243}$ Sancho de Salinas, vicario de Salinas y rector de Guembe. AGN, Protocolos Notariales, Salinas de Oro, Juan Miguel de Salinas, c. 2, n. 152, 11 de mayo de 1499. Polanco Melero, C.: Muerte y sociedad en Burgos, asegura que la mayoría de los clérigos de la zona burgalesa se hacían enterrar con sus familiares. Aunque existía otra posibilidad, pues en las iglesias parroquiales, solía existir una o dos fosas para su inhumación exclusiva, p. 295. Añade que en los pies de las iglesias solían ubicarse tumbas para aquellas personas pobres que no pudiesen pagarse una sepultura, p. 294.

${ }^{244}$ Los arqueólogos Inés TABAR y Jesús SESMA tuvieron la amabilidad de mostrarnos la localización de varias de estas fosas, constituidas como criptas. Concretamente, dos de ellas estaban situadas en el coro de la catedral de Tudela y, más específicamente, a la entrada y en el interior del mismo; en ellas se daría sepultura a los miembros del cabildo de dicha iglesia. Asimismo, Rodrigo Estevan, M. L.: Testamentos medievales aragoneses, p. 86, observa que el clero de Daroca también disponía de zonas comunes de inhumación, aunque no era preceptivo que se enterrasen en ellas.

245 Testamento de Juan de Castro, clérigo y beneficiado de Santa María de Tudela, AGN, Protocolos Notariales, Tudela, Sancho Ezquerro, c. 12, 10 de diciembre de 1484. Desea ser enterrado con su padre en la capilla de San Sebastián de Santa María de Tudela. La elección de sepultura de religiosos con familiares también está recogida por RODRIGo EsTEVAN, M. L.: Testamentos medievales aragoneses, ver p. 86 .

246 Testamento de Nadal Sanchiz de Linares, vecino de Tudela, viudo de Estefanía de Pola y casado en segundas nupcias con Mayor de Cernau. Elige su sepultura en la sepultura de la cofradía de San Martín, localizada en el cementerio de Santa María la Mayor de Tudela. AGN, Protocolos Notariales, Tudela, Martín Garceiz Don Costal, cuad. 1381-1383, f. 215-216, 4 de septiembre de 1383. Cfr. Polanco Melero, C.: Muerte y sociedad en Burgos, p. 295. También Rubio Semper, A.: «Piedad, honras fúnebres y legados», p. 244.

Hispania, LXV/1, núm. 219 (2005) 155-226 
fosa ${ }^{247}$. Como Juan Garceiz de Falces y su esposa Elvira Garceiz de Olaz, vecinos de Tudela, que eligen el cementerio de San Pedro de esta población como lugar de inhumación, con la madre y el abuelo de Elvira ${ }^{248}$. Sólo una mínima parte de las parejas de testadores prefiere a otros familiares como acompañantes en sus sepulturas, en lugar de sus consortes ${ }^{249}$

En el caso de personas viudas, es destacable el mayor número de mujeres que desean su sepelio con el cónyuge fallecido, por contrapartida a los hombres, los cuales parecen preferirlo junto con otros parientes ${ }^{250}$. Juana Íñiguez de Ujué, viuda de Pedro Jiménez de Ayuso y vecina de Tudela, en su testamento de 1369 elegía el lugar donde yacía su padre en San Jorge de Tudela. Sin embargo, en su codicilo de 1383, lo cambia por la sepultura de su marido, Pedro Jiméniz de Ayuso, en San Jaime ${ }^{251}$. Otros testadores, casados en segundas o terceras nupcias, escogen ser enterrados con el cónyuge fallecido. Como Juan de Logroño que lo dispone en San Francisco de Tudela con sus mujeres Francesca de Estorga y Beatriz ${ }^{252}$.

Por otra parte, un amplio sector de testadores eligen sepultura con sus progenitores; así se han recogido un total de 46 referencias sobre el deseo de ser sepultados con ambos padres. De tal manera, el padre, cabeza de familia de esta sociedad patriarcal, sigue siendo el preferido a la hora de la muerte, con 61 noticias (11\%) frente a las 48 personas (8\%) que eligen a su madre como com-

${ }^{247}$ De 67 documentos en los que los matrimonios deciden su sepultura, en 47 casos eligen su inhumación en la misma fosa. AleXANDre-BIDON, D.: La Mort au Moyen Âge, p. 152 asegura que, como consecuencia de los decretos de los liturgistas a fines de la Edad Media son muy escasos los matrimonios que yacen juntos en la misma sepultura, prefiriendo enterrarse con sus padres, como era preceptivo.

${ }^{248}$ AGN, Protocolos Notariales, Tudela, Martín Garceiz Don Costal, cuad. 1381-1383, f. 247249. Testamento de 28 de octubre de 1383.

${ }^{249}$ El matrimonio formado por García Martínez de las Masaderas y Elvira de la Fuente, vecinos de Tudela, decide ser enterrados por separado, cada uno con uno de sus abuelos, aunque próximos en el espacio, en el cementerio de Santa María Magdalena. AGN, Protocolos Notariales, Tudela, Martín Garceiz Don Costal, cuad. 1381-1383, f. 66, 30 de noviembre de 1381.

250 Contra los 47 casos de mujeres que eligen ser enterradas con su marido fallecido sólo 24 hombres desean su sepelio con su mujer. Cfr. CASTRO PINA I.: «Ritos e imaginário da morte», ver cuadro en p. 160, donde corrobora esta práctica. Además, arroja otros datos interesantes, como que los hombres eligen mayoritariamente la sepultura con su padre, mientras que las mujeres prefieren, en segundo lugar, a sus madres. En Jerez, en cambio, los viudos no manifiestan deseo alguno de ser enterrados con sus cónyuges fallecidos, ni en el caso de hombres ni en el de las mujeres. $C f r$. García GuZMÁN, M. M., ABELLÁN PÉrEZ, J.: La religiosidad popular de los jerezanos, pp. 74-80. Tampoco en Elche, Cfr. Álvarez ForTes, A. M.: El sentit de la mort en l'Elx, p. 82.

${ }^{251}$ AGN, Protocolos Notariales, Tudela, Martín Garceiz Don Costal, cuad. 1381-1383, f. 216219. Codicilo fechado en 6 de septiembre de 1383. En él se hace alusión a un testamento anterior con data de 2 de enero de 1369.

252 AGN, Protocolos Notariales, Tudela, Juan Martínez Cavero, c. 5, f. 131, 25 de septiembre de 1509 .

Hispania, LXV/1, núm. 219 (2005) 155-226 
pañera de descanso eterno 253 . Los hijos fallecidos también son tenidos en cuenta, al igual que los abuelos, de los cuales se han recogido respectivamente 40 $(7 \%)^{254}$ y $26(4 \%)^{255}$ menciones. Siguen en proporción los hermanos ${ }^{256}$, sue$\operatorname{gros}^{257}$, tíos ${ }^{258}$ y cuñados ${ }^{259}$. Aunque en menor grado, también se mencionan descendientes, como nietos o sobrinos ${ }^{260}$.

Muchos de los parientes anteriormente señalados se yuxtaponen en las tumbas sin un orden lógico, acomodándose a unos lazos que hacen de sus fosas lugares únicos para estudiar las relaciones de afecto que unían a cada familia ${ }^{261}$, como se puede comprobar en la documentación ${ }^{262}$.

Por último, cabe destacar que un significativo número de testadores tudelanos dispone la reagrupación de los restos dispersos de parientes sepultados bien en la misma iglesia o en otras parroquias de la ciudad, con el ánimo de configurar una sepultura que sea propia de esa familia ${ }^{263}$. De tal forma, Catalina Bendicho elige su enterramiento en el fosal o cementerio de San Salvador de

253 Catalina Jiménez de Ujué, vecina de Tudela, quiere ser inhumada con su madre Prima de Milagro en el cementerio de San Salvador de Tudela, AGN, Protocolos Notariales, Tudela, Martín Garceiz Don Costal, cuad. 1381-1383, f. 69-70, 23 de diciembre de 1381

25430 citan a hijos y 10 a hijas.

255 Con ambos abuelos 3 , con abuelo 16 y con abuela 7 .

${ }^{256}$ En total 23 noticias: a hermanos 3, a hermano 13 y a hermana 7.

257 Con suegros, 2 noticias; 16 con suegro y con suegra, sólo 1 de una mujer.

${ }^{258}$ En total 8 noticias. A tíos, entendido como matrimonio, 3; a tío 2 y a tía 3 referencias.

259 En el caso de dos testadoras.

2601 nieto y 1 sobrino.

${ }^{261}$ Cfr. CASTRO PINA, I.: "Ritos e imaginário da morte», ver cuadro en 160. Cfr. García GuZMÁN, M. M., ABELLÁN PÉREZ, J.: La religiosidad popular de los jerezanos, pp. 73-101, especialmente cuadro en p. 74 , donde aclara que hijos y padres son los familiares más demandados. ÁlvarEZ FORTES, A. M.: El sentit de la mort en l'Elx, pp. 81-82, donde se prefiere a padres, hijos y hermanos. Rodrigo Estevan, M. L.: Testamentos medievales aragoneses, pp. 87-89. García Herrero, M. C.: «Ritos funerarios y preparación para Bien Morir», pp. 94-95, CANTERA MONTENEGRO, M.: «Religiosidad en la Rioja bajomedieval», p. 121. RUBIO SEMPER, A.: «Piedad, honras fúnebres y legados», 244. Sin embargo, Gómez NieTO, L.: Ritos funerarios, pp. 64-65, MARANDET, M.-C.: Le souci de l'au-delà, p. 169 y CHIfFOlEAU; J.: La comptabilité de l'au-delà, pp. 183-186, destacan las preferencias por los ancestros (padres y abuelos, especialmente) y hablan de decretos canónicos por los cuales se aconseja la reunión de hombres y mujeres con sus familiares difuntos, especialmente antecesores.

262 Estefanía Cortel desea su enterramiento con sus hijos en San Nicolás de Tudela, delante del altar mayor. Y su hermana Elvira con su padre y hermanos en San Francisco. AGN, Protocolos Notariales, Tudela, Martín Garceiz Don Costal, cuad. 1381-1383, f. 34-39, 2 de agosto de 1381. García Pérez de Calvo decide ser enterrado con sus abuelos y con su padre en Santa María de Tudela. AGN, Protocolos Notariales, Tudela, Juan Martínez Cavero, c. 4, f. 237r.- 241r., 28 de octubre de 1505. Y García Sanz de Munárriz, vecino de Munárriz, establece que se le entierre en la fosa donde yacen su mujer y su hijo, reconstruyendo así en la muerte, el núcleo familiar del que disfrutó en vida. AGN, Protocolos Notariales, Salinas de Oro, Juan Miguel de Salinas, c. 4, 22 de agosto de 1510.

263 Álvarez Fortes, A. M.: El sentit de la mort en l'Elx, p. 82, nota 207 y GARCÍA GUZMÁN, M. M., ABellán PÉrez, J.: La religiosidad popular de los jerezanos, pp. 96-101. CANTERA MONTENegro, M.: «Religiosidad en la Rioja bajomedieval», p. 122. ChIFfoleAU, J.: La comptabilité de l'au-delà, p. 181.

Hispania, LXV/1, núm. 219 (2005) 155-226 
Tudela, lugar donde yacen sus suegros, marido e hijo y da limosna a esta iglesia para que les concedan una fosa en el interior de la misma, a donde serían desplazados los restos de todos ellos:

una fuessa dentro del cuerpo de la iglesia de San Saluador donde sean movidos los guesos de los dichos finados et los suyos et si antes de haberla muriere et los suyos por que sus animas reciban mas continuas las oraciones que en la dicha yglesia por finados de ellos se faran...264.

Martín de Rada y Gracia de las Navarras, con sus descendientes: pora perpetuydat. sepelir en aqueilla los vuestros cuerpos $i$ de vuestras criazones $i$ de los descendientes de vos $i$ deillos ${ }^{265}$. Jimeno de San Pedro, con los suyos: donde los suyos están enterrados en Santa María la Mayor de Tudela ${ }^{266}$. Y Pero Orh, señor de la casa de Aldaloit y vecino de Garzáin, en la fosa de su casa, sita en el cementerio de San Martín de Garzáin ${ }^{267}$.

En conclusión hay que señalar que la familia es la célula principal que vertebra esta sociedad tanto en vida como en muerte. Por ello, sobresale la sepultura con los parientes más cercanos de los cuales son preferidos los ascendientes directos como padres y abuelos, los descendientes directos como hijos así como los hermanos. Sin embargo, las familias más modestas disponen de un número limitado de tumbas, generalmente en el cementerio, en las cuales tienen cabida menor cantidad de cuerpos. Y sus sepulturas están situadas de forma más dispersa en una o diferentes parroquias. Sin embargo, los grandes linajes, con mayores posibilidades, agrupan de una manera más compacta a sus familiares. De hecho, las estirpes más poderosas de Tudela, por ejemplo, en lugar de una única sepultura, dispondrían de varias agrupadas en un lugar común de su propiedad, como una capilla, en las cuales reposarían sus diferentes miembros ${ }^{268}$. A pesar de ello, algunos testadores eligen como compañeros, en espera de la Resurrección final, a personas que no tienen relación consaguínea con ellos, como criados - aunque se les considera parte de la misma ${ }^{269}$ - o hermanos cofrades ${ }^{270}$.

\footnotetext{
${ }^{264}$ AGN, Protocolos Notariales, Tudela, Juan Martínez Cavero, c. 5, f. 121, 3 de agosto de 1510. Testamento de Catalina Bendicho, viuda y vecina de Tudela.

265 AGN, Protocolos Notariales, Tudela, Martín Garceiz Don Costal, cuad. 1381-1383, f. 250 251, 29 de octubre de 1383. Concesión de sepultura en el coro de San Francisco de Tudela a Martín de Rada y Gracia de las Navarras.

266 AGN, Protocolos Notariales, Tudela, Juan de Frías, c. 8, f. 58v.-59v., 27 de junio de 1497.

${ }^{267}$ Minuta y testamento, fechados en 27 de enero de 1491. AGN, Protocolos Notariales, Santesteban, Juan de Ursúa, c. 1, nos. 68 (testamento) y 69 (minuta).

${ }^{268}$ Baste recordar los ejemplos ya comentados de las familias tudelanas de los Egüés, Magallón o Veraiz, que disponen de capillas privadas donde se reúnen las tumbas de miembros del mismo linaje. Cfr. POlANCO Melero, C.: Muerte y sociedad en Burgos, p. 303.

${ }^{269}$ De tal modo, María García de Ibero, viuda de Sancho de Ilzarbe, escoge como lugar de reposo la fosa de García Gorría de Ilzarbe, señor de la casa donde vivía, ubicada en el cementerio de

Hispania, LXV/1, núm. 219 (2005) 155-226
} 
El agrupamiento de los restos mortales favorece, asimismo, tanto a los propios difuntos como a los vivos, pues el cuidado de sus almas es más efectivo. Los parientes y amigos que velasen por sus almas así como los clérigos que celebraran determinados oficios religiosos agradecerían esta economía de oraciones, pues las que se realizaban por uno de los integrantes de una sepultura se extenderían beneficiosamente a sus compañeros. De tal manera, las capellanías encargadas en una misma capilla sè ofrecían por el alma de un determinado difunto pero serían extensivas a todos los parientes allí depositados. De igual modo, la bendición de una sepultura alcanzaría a todos los que reposasen en ella. Así, se conforma una comunidad de fieles - integrada por los vivos y los difuntos- en la cual todos se comunican a través de una identidad cultural y religiosa.

\subsection{Memoria funeraria. Inmediata, perpetua, aniversarios, capellanías}

En el Occidente medieval se mantiene una práctica social estrechamente ligada con la muerte, se trata de la costumbre de evocar y conmemorar a los difuntos, es decir, mantenerlos en la memoria y en el recuerdo. Esta conmemoración, tan estrechamente ligada a la propia religión cristiana, pues Cristo instaura la Eucaristía indicando "haced esto en memoria mía», tiene una clara dimensión social, una función a la hora de la estructuración del grupo social, ya que de este modo los muertos siguen permaneciendo entre los vivos. Además, según un modelo tradicional, que en cierta medida ya estaba fijado en la sociedad antigua, los vivos eran quienes debían ocuparse de sus difuntos. Llegados a este punto estamos ante una auténtica paradoja, pues son los muertos quienes dan vida a una gran parte de la sociedad de los vivos que se dedican a rezar y a trabajar por ellos 271 .

Por otro lado y siguiendo con el esquema clásico de Philippe Ariés, la concepción medieval de la muerte sufre una mutación a partir del siglo XII y comienzos del XIII, mediante la cual deja de ser aquella mort apprivoisée, esperada y reconocida, para pasar a la mort de soi, que enfoca con mayor incidencia la separación del cuerpo y del alma, así como el juicio particular e inmediato de cada individuo. En todo caso se debe hablar de una lenta emergencia del individuo aunque sin olvidar el carácter parcial de los textos documentales. En este sentido se ha de tener en cuenta que la fuente testamentaria permite una aproximación incompleta a la mentalidad de los fieles. Si bien es cierto que su

\footnotetext{
San Esteban de este lugar. Minuta fechada en 9 de marzo de 1504. Testamento de 10 de marzo de 1504, AGN, Protocolos Notariales, Salinas de Oro, Juan Miguel de Salinas, c. 2.

270 Testamento ya citado de Nadal Sanchiz de Linares, viudo de Estefanía de Pola y casado con Mayor de Cernau. Sepultura de la cofradía de San Martín, cementerio de Santa de Tudela. AGN, Protocolos Notariales, Tudela, Martín Garceiz Don Costal, cuad. 1381-1383, f. 215-216, 4 de septiembre de 1383.

271 AleXANDre-Bidon, D.: La mort au Moyen Âge, p. 13.
} 
análisis facilita la elaboración de una serie de indicaciones o tendencias del individuo frente a ese momento tan universal y trascendental como es su muerte.

Sin embargo, parece evidente que esta emergente individualidad tiene su más claro exponente en el momento de fijar por escrito y ejecutar todas aquellas disposiciones de carácter piadoso que pueden ser calificadas de modo genérico como sufragios por el alma del difunto. El testamento no es exclusivamente un acto social o jurídico, sino también se presenta como un acto de piedad y $\mathrm{fe}$, donde la salvación del alma es la principal preocupación latente ${ }^{272}$. De modo que todo testador disponía en este documento el reparto de sus bienes, pero con un matiz importante: una buena parte de estos se destinarían en forma de oraciones, misas, limosnas, a conseguir la salvación eterna. En suma, las mandas pías ocupaban un lugar importantísimo en su estructura.

En este sentido, los testamentos tienden a acentuar ciertos aspectos que son prioritarios para el testador y a omitir otros. Así se entiende la tendencia a contabilizar con detalle las prácticas piadosas que se deben llevar a cabo tras su muerte. El objetivo esta bien claro, se trata por una parte de subrayar un sentimiento de arrepentimiento y por otra de obtener las gracias que se irían acumulando con el fin de reducir el tiempo en el Purgatorio 273 . No se debe olvidar que el desarrollo de la doctrina del Purgatorio comprendía que las penas podían ser reducidas en vida, tal y como se comprueba en esa mentalidad del pecado asociado a las tarifas de penas que se debían expiar, también tras la muerte. De modo que la imagen del Purgatorio es más activa, y así aparece formulada en pasajes de las Sagradas Escrituras como el de los Macabeos (2 Mac 12, 4446) o la primera carta de San Pablo a los Corintios 3, 10-15274.

Aunque en muchas ocasiones el testador delegará esta tarea en sus albaceas, cabezaleros, lo cual nos permite imaginar la existencia de unos usos funerarios establecidos y generalizados entre la población. Sin embargo, la mayor parte de las veces nuestros testadores, interesados en velar por el bien de su alma, señalan y precisan cada una de las disposiciones en orden a los sufragios y demás acciones piadosas que debían efectuarse una vez hubiera fallecido. De modo que los testamentos, reconociendo a los individuos una cierta autonomía, les autorizan a derogar la costumbre. En estos casos la precisión y el detalle que

272 Ibidem, p. 74.

273 BURGESS, Charles: «Late Medieval wills and pious convention: testamentary evidence reconsidered» en HICKS, M. A.: Profit, Piety dans the professions in later Medieval England (Gloucester) 1990, pp. 14-33/ 16.

2741 Corintios, 3, 10-15: «Que cada uno mire como edifica. Pues ninguno puede poner otro cimiento fuera del que ya está puesto que es Jesucristo. Si alguno edifica sobre este cimiento con oro, plata, piedras preciosas, madera, heno, paja, la obra de cada cual quedará al descubierto; pues aquel día se manifestará, porque se revelará en el fuego, y ese mismo fuego probará la calidad de la obra de cada cual. Si la obra que uno edificó permanece, recibirá premio; si la obra de alguien arde, sufrirá el daño; él, sin embargo, se salvará, pero como si pasara a través del fuego».

Hispania, LXV/1, núm. 219 (2005) 155-226 
caracterizan este tipo de documentos evidencian una especial consideración hacia los destinos del alma una vez que abandona el cuerpo mortal.

\subsection{Mandas pías}

\section{La celebración eucarística, sufragio universal.}

Desde la Alta Edad Media se va imponiendo la idea, tal y como aparece por ejemplo en las vidas de los santos, de la intervención de los vivos a favor de los muertos a través de oraciones, limosnas, ayunos y sobre todo mediante el sacrificio de la misa ${ }^{275}$. Esta eficacia de los sufragios es defendida por San Agustín y Santo Tomás, quien dará prioridad a tres clases: la limosna, la plegaria y la misa, sobre todo la que contiene oraciones especiales por los difuntos, por ser el único sacramento cuya eficacia es comunicable ${ }^{276}$.

La misa era indudablemente el instrumento salvador esencial, capaz de beneficiar a vivos y a muertos de los méritos acumulados por el sacrificio redentor de Cristo renovado sobre el altar ${ }^{277}$. En la Eucaristía se encuentra la verdadera economía de la redención del hombre, pues en ella el Hijo se ofrece al Padre como víctima perfecta, alcanzando la salvación para todos. En consecuencia se convierte en el sufragio por excelencia y al mismo tiempo pone de manifiesto la especial comunión de los santos en el seno de la Iglesia.

Generalmente, estas celebraciones litúrgicas se oficiaban siguiendo dos parámetros: por una parte, la repetición, novena, cabo de año; y por otra la perpetuidad, como las capellanías y aniversarios. En este último caso estamos ante el culmen de esa imperecedera memoria de los muertos entre los vivos ${ }^{278}$.

En el caso navarro no se detecta ninguna particularidad a la hora de celebrar estos sufragios por los difuntos. De manera que el ritmo de celebraciones sigue los esquemas clásicos, sin observarse tampoco una tendencia al incremento cuantitativo de misas encargadas. La memoria fúnebre tiene como exponentes las novenas, cabo de novena y cabo de año o aniversario. Junto a ello se constata, aunque en menor medida, ciclos de misas como las trentenas ${ }^{279}$, o las treinta y tres misas de San Amador ${ }^{280}$, que aparecen en 93 de los testamentos

\footnotetext{
275 VOVELLE, Michel: La mort et l'Occident. De 1300 à nos jours, 1983, París, pp. 64-65.

276 MARTínEZ. GIL, F.: La muerte vivida, p. 125.

277 GÓMEZ NiETO, Leonor: «Las misas por los difuntos. Testamento bajomedievales» en En la España medieval (Madrid) 15 (1992), pp. 353-366/ 353.

278 AleXANDre-Bidon, D.: La mort au Moyen Age, p. 58.

279 MARANDET, M.-C.: Le souci de l'au-delà, p. 342. La trentena gregoriana comprende un conjunto de 30 misas bajas celebradas a razón de una por día consecutivo o bien en el mismo día.

280 García Villoslada, Ricardo (dir.): Historia de la Iglesia en España (Madrid) 1980, vol. III-1, p. 373: «San Amador personaje al que se identifica con el Zaqueo de los evangelios, quien casado con la Verónica, habría venido a las Galias, padeciendo el martirio en Rocamadour, donde tenía su principal santuario».
} 
manejados correspondientes todos ellos en su mayoría a vecinos de Tudela, salvo cinco que provienen de Puente la Reina ${ }^{281}$.

Sin embargo, cabe señalar algunos ejemplos quizás discordantes desde el punto de vista cuantitativo. Es el caso de María Sanz de Echaurren, viuda y vecina de Echaurren que dispone de fazer dezir en todo el dicho anno que yo be finado cada semana una missa de requiem en la iglesia parroquial de San Román ${ }^{282}$. O aún más destacado es el testamento de Sancho Roncal y su mujer Gracia de Let, vecinos de Urdánoz, quienes a comienzos del siglo XVI disponen toda una larga serie de mandas piadosas como la celebración de sendas novenas, aniversarios, trentenas cerradas y trentenas sueltas y fundan una capellanía, pero además ordenan a su cabeçaleros que luego como nosotros seremos finados y nostros cuerpos enterrados nos ffagan dezir por cada uno de nos quinze missas las cada tres en bonor e reverencia de la Trinidat las cada cinquos en honor e reverencia de la Virgen María ${ }^{283}$.

Estas misas votivas en honor a la Virgen aparecen raramente entre los testamentos manejados y en mayor medida se trata de aquellas que hacen referencia a los siete «gozos de María» ${ }^{284}$. A este respecto se ha de señalar que la invocación mariana en la hora de la muerte estaba perfectamente arraigada en la espiritualidad medieval. Desde el siglo XI se le atribuye a Santa María el milagro de poder sacar las almas del infierno, de manera que la Madre de Dios intercede por los pecadores tal y como se invoca en el Ave María ${ }^{285}$. En este orden se encuadra la donación de María Ruíz, vecina de Tudela, quien en su testamento de 1505 dispone la suma de cinco groses para el hospital de Santa María de Gracia de Tudela para que la Virgen interceda por ella ${ }^{286}$.

Uno de los ejemplos más paradigmáticos de acumulación de sufragios a favor de su alma es el testamento incompleto, pues sólo se conserva una parte del

281 AGN, Protocolos Notariales, Puente la Reina, Martín Brun, 1491, c. 1, n. 1; 1500, c. 1, n. 3; 1502 , c. 1 , n. $2 ; 1507$, c. 1 , n. $2 ; 1512$, c. 1 , n. 2.

282 AGN, Protocolos Notariales, Salinas de Oro, Juan Miguel de Salinas, 1482, c. 1, n. 180. Esto mismo dispone Gracia Sanz de Puente, mujer de Pedro de Idiazábal, vecina de Puente la Reina. AGN, Protocolos Notariales, Puente la Reina, Martín Brun, 1501, c. 1, n. 1.

283 AGN, Protocolos Notariales, Salinas de Oro, Juan Miguel de Salinas, 1510, c. 4. s. c. Un modelo similar es el testamento de Diego Alfonso, vecino de Cascante, quien encarga tres misas en honor de la Santísima Trinidad, cinco en reverencia de las llagas de Cristo y siete en reverencia a los gozos de Santa María: AGN, Protocolos Notariales, Tudela, Miguel Martínez Cavero, 1498, c. 29, f. 8r.-11v. Ya en el siglo XVI, el testamento de García de Cerdán (1504) y Juan de Novallas (1505): AGN, Protocolos Notariales, Tudela, Miguel Martínez Cavero, 1504, c. 4, f. 117 r.-119v. y 1505, c. 4, f. 154r.-160v.

${ }^{284}$ AGN, Protocolos Notariales, Puente la Reina, Martín Brun, 1507, c. 1, 2. Testamento de María de Urtubia. AGN, Protocolos Notariales, Tudela, 1447, c. 1. Testamento de María Sánchez de Añorbe, vecina de Tudela. En este caso no se trata de misas sino de pobres a los que manda dar de comer. Serán un total de 15 en reverencia delas cinco plagas de nuestro seynor Ihesu Christo et dela Trinidad et de los siete gozos de la Virgen seynora Sancta María.

285 PhILIPPART, Guy: «Le récit miraculaire marial dans l'Occident médiéval» en Le culte de la Vierge dans la société médiévale, París, 1996, pp. 562-587/571.

286 AGN, Protocolos Notariales, Tudela, Juan Martínez Cavero, 1505, c. 4, f. 172r.-177v.

Hispania, LXV/1, núm. 219 (2005) 155-226 
mismo, de Juan de Goyerhe quien además de las mandas pías acostumbradas ordena diez trentenas comenzando luego del dia que mi anima partiere deste mundo al otro y encarga a su hijo y heredero que haga cantar un trentenario cada año durante los próximos treinta años ${ }^{287}$.

Todas estas misas contribuían a mantener vivo el recuerdo del difunto y a asegurarse los sufragios por su alma de un modo indefinido. Lógicamente se trataba de concentrar el mayor número de ellas en los días próximos al fallecimiento, con el fin de que éstas ayudasen al alma en el momento más decisivo, el juicio particular. Así por ejemplo, Martín Guerrero, vecino de Tudela, encarga que durante los tres primeros días de la novena se digan tres misas diarias, una de las cuales sería cantada y debía contar con la presencia de un diácono y subdiácono. A lo que seguirán cuatro trentenarios planos de misas de Réquiem $^{288}$. O bien a comienzos del siglo XVI Juana Migueliz Dalvaro, acomodada vecina y viuda Tudela, dispone además de enterrarse en la catedral delante del altar de San Gregorio, que el capitol dela dicta yglesia de Santa Maria ayan de venyr por mi cuerpo e me diga una missa cantada enel altar mayor en cada bun día delos tres primeros ${ }^{289}$.

Tampoco es extraño encontrar entre las disposiciones piadosas el encargo de celebrar varias trentenas cerradas, en concreto tres ${ }^{290}$; es decir tres ciclos de misas seguidas probablemente al finalizar la novena, a los que algunos añaden la celebración de trentenas sueltas, también llamados trentenarios planos o de Réquiem a lo largo del primer año posterior al fallecimiento ${ }^{291}$. Por lo tanto, los trentenarios tienden a acumularse, ya que además serían más económicos que la fundación a perpetuidad de una capellanía o aniversario y así por ejemplo Juana del Arco, vecina de Tudela encarga diez trentenarios ${ }^{292}$.

A fines de la Edad Media cada familia rezaba por sus muertos y en los testamentos suplican a sus parientes que lo hagan por ellos, sobre todo en los tres días

287 AGN, Protocolos Notariales, Santesteban, s.d, c. 1.

288 AGN, Protocolos Notariales, Tudela, Sancho Ezquerro, 1482, c. 12, f. 11r.-13 v. Esto mismo aparece en el testamento de Francisca Martínez de Calahorra, vecina de Tudela, 1483, c. 12, f. 76 r.$79 \mathrm{v}$.

289 AGN, Protocolos Notariales, Tudela, Sancho Ezquerro, 1500, c. 12, fajo 1482-1507.

${ }^{290}$ AGN, Protocolos Notariales, Salinas de Oro, Juan Miguel de Salinas, 1494, c. 2. n. 36 (testamento de Sancho Pérez de Azanza); 1506, c. 3 (testamento de Fernando Martínez de Izurzu); 1511, c. 4 (testamento de Juan de Guembe); AGN, Protocolos Notariales, Santesteban, Juan de Ursúa, 1491, c. 1, n. 68 (testamento de Pero Orh); AGN, Protocolos Notariales, Elizondo, Juan de Elizondo, 1512, leg. 1, n. 341 (testamento de Pedro de Berroet); AGN, Protocolos Notariales, Tudela, Martín Garceiz don Costal, 1383, f. 242-244 (testamento de Salvador, vecino de Tudela); Tudela, Juan de Frías, 1476, c. 8, f. 2 (testamento de María Sanz); AGN, Protocolos Notariales, Tudela, Martín Garceiz don Costal, 1383, f. 215-216 (testamento de Nadal Sanchiz de Linares).

${ }^{291}$ AGN, Protocolos Notariales, Salinas de Oro, Juan Miguel de Salinas, 1506, c. 3 (testamento de María de Huarte); 1510 , c. 4 (testamento de Sancho Roncal de Urdánoz y Gracia de Let). A los que añadimos 22 testamentos tudelanos.

292 AGN, Protocolos Notariales, Tudela, Sancho Ezquerro, 1491, c. 12, f. 268r.-269v. 
que siguen a la muerte, dado el carácter simbólico de esta cifra que evoca la Resurrección de Cristo. Así María Pascuala, viuda de Lope de Arbizu y vecina de Puente la Reina encarga que a los tres día de su muerte, así como en la novena y cabo de año se celebren cinco misas diarias ${ }^{293}$. Y Juliana de Magallón, viuda de Tudela pide que se digan en el convento de San Francisco los tres días con el día de mi deffunsion sendas missas cantadas con cada dos baxas salliendo los sacerdotes sobre mi fuessa con la luminaria de candelas y offrendas negeessarias ${ }^{294}$.

No obstante, dentro del ámbito espacial analizado -el reino de Navarraes notable la diferencia que se observa entre los testamentos provenientes de núcleos rurales, más aislados y quizás con una economía menos floreciente, de aquellos conservados en la villa de Tudela. En este último caso, una mejor vitalidad económica de esta populosa ciudad ribereña queda también de manifiesto a la hora de cuantificar las mandas pías que ordenan los testadores ${ }^{295}$. Gutier García de Aguilar que se hace enterrar en la capilla de Santa Catalina de la catedral tudelana, funda un aniversario a perpetuidad por el alma de su mujer ya fallecida y de todos los difuntos, que se celebrará el día siguiente a la festividad de Todos los Santos; más otros dos aniversarios por el alma suya y de sus padres celebrándose uno la víspera de Santa Catalina y otro el tercer día después de la festividad de San Pedro y San Pablo ${ }^{296}$. En este caso debemos hacer notar como en muchas ocasiones el propio testador elige y deja fijada su memoria funeraria en un día concreto del calendario litúrgico y no en el día de su muerte como era lo general ${ }^{297}$. Ya fuese junto a la festividad de un santo ${ }^{298}$, acudiendo de este modo a su intercesión, o bien asociado a la festividad de todos los difuntos tan arraigada en la Europa bajomedieval.

De igual modo, en este núcleo urbano parecen ser una práctica habitual las llamadas misas de Réquiem tras la muerte del difunto. En suma, se trata de la

293 AGN, Protocolos Notariales, Puente la Reina, Martín Brun, 1493, c. 1, n. 7. Además encarga una trentena revelada de San Amador.

294 AGN, Protocolos Notariales, Tudela, Pedro de la Torre, 1494, c. 14.

295 LEROY, B.: «Tudela en 1381-1383 à travers le registre», pp. 723-739.

296 AGN, Protocolos Notariales, Tudela, Martín don Costal, 1328, f. 110-113. Además este individuo hace importantes donaciones a la obra del hospital de los Ballesteros (10 libras de dineros carlines), a la obra del hospital de San Francisco de Tudela (50 sueldos carlines).

297 Por ejemplo al día siguiente de la festividad de Nuestro Señor, San Salvador, tal y como dispone Juana Pérez de Miranda, vecina de Tudela, que se diga una misa de Réquiem en la iglesia de San Salvador. AGN, Protocolos Notariales, Tudela, 1477, c. 1. O bien Gabriel de Pera, vecino de Tudela, quien funda dos aniversarios, uno de los cuales se celebrará el día después de Santa María en marzo: AGN, Protocolos Notariales, Tudela, Juan Martínez Cavero, 1490, c. 3, f. 53v.-54r. Otro ejemplo es la fundación de aniversario por parte de Juan de Miranda que se celebraría el día siguiente a la Epifanía: AGN, Protocolos Notariales, Tudela, Juan Martínez Cavero, 1500, c. 4, fajo 1494-1500, f. 16v.-17r.

298 Así el canónigo racionero de la Catedral, Greva de Aibar, dispone que su aniversario se diga el día de San Dámaso. AGN, Protocolos Notariales, Tudela, Sancho Ezquerro, 1485, n. 29. Mientras que Sancho Serrano, vecino de Tudela, pide que se celebre la víspera de San Miguel. En este caso el testador también manda ser enterrado en la parroquia de San Miguel y que ahí se oficien sus sufragios. Protocolos Notariales, Tudela, Sancho Ezquerro, 1485, n. 56.

Hispania, LXV/1, núm. 219 (2005) 155-226 
misa con el oficio propio de difuntos que, al igual que los otros casos, se ajusta a los ciclos repetitivos, ya sea anualmente, dos o tres veces al año o a veces durante treinta días seguidos. Incluso, a comienzos del siglo XVI, nos encontramos algunos ejemplos de fundaciones de misas de Réquiem bajas a perpetuidad. Este es el caso de Pedro de Egida y su mujer que además determinan que se celebre a otro dia de la consagracion de la dicha iglesia, es decir de la parroquia de San Miguel donde recibirán sepultura ${ }^{299}$.

Sin embargo, a nuestro juicio y dentro de esta monótona sucesión de encargos piadosos cabe señalar cómo la memoria del difunto engloba no sólo al testador sino según una fórmula frecuentemente empleada a todas a las almas a mi encomendadas. En cierto sentido esta expresión refleja la idea de sufragio, es decir, de ayuda espiritual en el seno de la comunidad de fieles, entre la Iglesia militante y la «naciente Iglesia purgante». En muchos casos este tipo de auxilio genérico se individualiza y el testador pasará a mencionar a aquellos miembros de la familia más próximos a los que quiere beneficiar espiritualmente. Así por ejemplo, resultaba una práctica frecuente entre las viudas que a la hora de testar encargasen entre sus mandas pías sufragios por sus maridos difuntos ${ }^{300}$. Y entre la documentación manejada son 22 los testamentos que así lo reflejan. Sirva como modelo el caso de María Delgada, vecina de Tudela, quien manda que por las animas de sus maridos Lope Sanchez et Ioban de Lexido que le sean fecho dezir un trentenario de missas de Sant Amador plano ${ }^{301}$. E incluso, a veces estando casadas en segundas nupcias no dejan de recordar la memoria de sus primeros cónyuges, como en el caso de Estefanía de Lisanca, mujer de Juan de Estella, vecinos de Tudela, quien además de mandar ser enterrada en la sepultura de su primer marido, Juan de Aparicio, encarga un trentenario por su alma ${ }^{302}$.

En segundo lugar, pero no por ello de menor importancia, suelen aparecer los hijos fallecidos antes que sus padres, quizás habiendo muerto de una manera trágica y sin recibir el auxilio espiritual, como la viuda Águeda Pinilla quien recuerda a su fijo Miguel del Palo aquien Dios perdone es muerto enla mar cabo Corcega adonde nose le ha becho honrra ni ayuda alguna que le sea fechos enel monesterio de Sant Francisco sus enterrorios novena y cabo de novena et le sea levado su aynal de oblada y candela et complido su aynal le sea fecho cabo deayno honrradamente ${ }^{303}$.

Pero el círculo de parientes se sigue ampliando a otros miembros que también son objeto de esa memoria fúnebre dentro del clan familiar. Así que en

299 AGN, Protocolos Notariales, Tudela, Juan Martínez Cavero, 1500, c. 4, fajo 1494-1500, f. 23 r. Son un total de 182 testamentos los que recogen esta práctica religiosa.

300 Esto mismo ocurre en sentido inverso, así en 16 testamentos los maridos recuerdan a sus mujeres difuntas.

301 AGN, Protocolos Notariales, Tudela, Juan Martínez Cavero, 1491, c. 3, f. 11.

302 AGN, Protocolos Notariales, Tudela, Juan Martínez Cavero, 1509, c. 5. Al igual que María de Rueda, mujer del honrado García Navarro de Fustiñana, vecinos de Tudela. AGN, Protocolos Notariales, Tudela, 1508, Martínez Cavero, c. 5, f. 146.

${ }_{303}$ AGN, Protocolos Notariales, Tudela, Juan Martínez Cavero, 1508, c. 5, f. 150 . Otros 24 testamentos dan ejemplo de ello.

Hispania, LXV/1, núm. 219 (2005) 155-226 
sentido ascendente se incluye a la primera generación, los padres, y en raras ocasiones a la segunda, los abuelos (2). Estos antecesores juegan un papel muy destacado sobre todo a la hora de elegir lugar de sepultura pues es bastante frecuente pedir ser enterrados junto a uno de sus progenitores, y en menor medida con los suegros, como en el caso de cuatro testamentos tudelanos correspondientes a cuatro viudas ${ }^{304}$.

Finalmente, y de manera más aislada aparecen parientes de carácter colateral como tíos o sobrinos. Como Catalina Jiménez de Ujué, vecina de Tudela que en su testamento de 1381 dispone celebrar un annyal de misa de requiem por el alma de Sancho Enequo, su tío, el qual era tenida de celebrar la dita mi ma$d r e^{305}$. O la tudelana Bartolomea de Arlás, viuda de Lope de Ujué, en cuyo codicilo la relación de familiares supera todo lo visto hasta ahora. De modo que manda celebrar medio añal de misas por las almas de aquellos que no le sobrevivieron, parientes y vecinos, que probablemente tal y como se deduce de sus nombres eran todos menores de edad: Johaniella, su sobrina; Johenot, hijo de Johan Garceiz de Ujué; Murdaneta, su sobrina; Bartolomé, hijo de Valero; García de Olite, su sobrino; Pedruelo, hijo de Miguel Marro; Johaniella, hija de Martín Sanchiz de Caparroso ${ }^{306}$.

Por otro lado y en cuanto a la perpetuidad de la memoria, como se ha dicho, son dos las vías mediante las que quedaba garantizado el sufragio «eterno» por un alma: la fundación de aniversarios y capellanías. En primer término, contamos con 37 documentos que son exclusivamente fundaciones de aniversarios, a los que hay que añadir otros 60 en su mayoría testamentos, en los que se dispone la base económica necesaria para sostener esta disposición anual. En este sentido, esta práctica religiosa no presenta ninguna particularidad destacable salvo aquellos 23 ejemplos tudelanos fechados entre 1495 y 1512 en los que se mandaba tañer la campana María de la catedral el día del aniversario. Así, la documentación habla de aniversario nobilium et magnatum de campana Maria y su valor estaría entre unos 15 y 20 groses.

Junto a ello destaca la fundación de capellanías en las que las misas por sus almas y los difuntos de sus familias se repetían diaria y perpetuamente. Es evidente que sólo los testadores con mayor poder económico podían fundarlas. Aquellos que no disponían de rentas suficientes se limitarán por ejemplo a encargar medias capellanías ${ }^{307}$. Estas sumas dejadas por el testador tenían como fin mantener al capellán, y en nuestro caso oscilan entre los 24 florines y los 12 florines para una media capellanía. El capellán a su vez estaba encargado de

${ }^{304}$ AGN, Protocolos Notariales, Tudela, Juan Martínez Cavero, 1505, c. 4, f. 98r.-101v.; f. 112 r.-117v.; 1490, c. 3, f. 79r. y 79v.-80v.

${ }^{305}$ AGN, Protocolos Notariales, Tudela, Martín Don Costal, 1381, f. 69-70. Contamos con otros tres ejemplos en la documentación manejada.

306 AGN, Protocolos Notariales, Tudela, Martín Don Costal, 1381, f. 15-17.

307 Son un total de 43 documentos, principalmente testamentos, los que mencionan la fundación de medias capellanías.

Hispania, LXV/1, núm. 219 (2005) 155-226 
oficiar las misas que solían ser celebradas en una capilla particular, si existían, o en un altar consagrado a un santo de especial devoción del difunto ${ }^{308}$. Romea Jiménez de Bariellas, viuda de Ponz de Eslava, manda enterrarse en la capilla de San Eloy de la catedral de Tudela, y en esa misma capilla funda una capellanía perpetua en la que el clérigo encargado debía servir de todos días atodas las oras canonicas dela noche idel dia enel coro dela dita yglesia icada que oviere dita la dita missa encada un dia salga sobre la sepultura dont yo sere sepelida revestido con la cruz i lagua bendicha diziendo las oraciones iresponsos de difuntos et por las animas de mi padre idemi madre i por la mia ${ }^{309}$.

Esta práctica funeraria solía ser bastante frecuente entre los clérigos, de modo que en 1512 Pedro de Egüés, presbítero, funda una capellanía en la capilla de la Transfiguración de la catedral de Tudela, y dos años antes Martín de Egüés, abad de Fitero, lo hace en el altar dedicado a San Juan Evangelista ${ }^{310}$. También aparece entre los canónigos de la catedral, como García de Caparroso, o Pascual de Magallón, quien en su testamento de 1508 dispone enterrarse en la capilla de San Eloy, donde yacía su madre y además funda una capellanía. Al parecer este lugar estaba vinculado a su linaje, pues destina una considerable suma a la obra de un retablo con su armas ${ }^{311}$.

Estos clérigos y religiosos ocupan un lugar de máxima relevancia entre el mundo de los vivos y los difuntos, pues son quienes se dedican a la gestión de la memoria de los muertos. María Iñiguez de Ujué pide que el día de su fallecimiento todos los clérigos de la villa de Tudela leyesen el salterio dos veces en voz alta, al mismo tiempo requiere su presencia en los días de la novena. Finalmente el día de su aniversario, víspera de la festividad de Santa María, celebrada en el mes de septiembre, un vicario y seis clérigos dirán sus oraciones y responsos por su alma y la de sus padres sobre su sepultura, ceremonia que repetirán todos los días feriados ${ }^{312}$. En relación a este último punto, parece ser una práctica bastante establecida el rezo del responso sobre la tumba del difunto. El clérigo oficiante de la misa, al acabar la ceremonia, salía revestido y acompañado de unos acólitos portando una cruz y llevando agua bendita, dirigiéndose al sepulcro donde recitaba las oraciones propias de difuntos: et fin de la missa e bun dia salgan revestidos con la cruz e agua bendicta e digan los responssos conoscidos en la santa iglesia acostumbrados sobre la fuessa ${ }^{313}$.

308 Rodrigo Estevan, M. L.: Testamentos medievales aragoneses, p. 133.

309 AGN, Protocolos Notariales, Tudela, Martín Don Costal, 1383, f. 192-196.

310 AGN, Protocolos Notariales, Tudela, Juan Martínez Cavero, 1512, c. 6, fajo 1512, f. 60r.62v. Y 1510, c. 5, f. 11r.

${ }^{311}$ AGN, Protocolos Notariales, Tudela, Juan Martínez Cavero, 1508, c. 5, f. 201. García de Caparroso funda una capellanía en 1508: AGN, Protocolos Notariales, Tudela, Juan Martínez Cavero, 1508 , c. 5, f. 82.

312 AGN, Protocolos Notariales, Tudela, Martín Don Costal, 1383, f. 211-214.

313 AGN, Protocolos Notariales, Tudela, 1434, c. 1. María de Arnalt. Otros ejemplos en Tudela: Sancho Ezquerro, 1478, c. 12, f. 69r.-70v. (testamento de Felipa Delgado); Pedro Jiménez de Cas- 
También una destacada presencia de religiosos, en particular de frailes mendicantes, es la que dispone para todas las ceremonias litúrgicas de orden fúnebre Juan de la Mota, vecino de Buñuel. De modo que diez frailes del convento de San Francisco de Tudela ${ }^{314}$ serán los encargados de oficiar su funeral, diciendo cada uno de ellos una misa, al igual que el cabo de año y los cuatro trentenarios llanos por su alma y la de su mujer ${ }^{315}$.

En algunos testamentos encontraremos mandas a favor de estos personajes de vida consagrada. Así Ochoa de Izurzu deja al abad de San Andrés de Izurzu, donde recibirá sepultura, una suma de veinticuatro sueldos y medio ${ }^{316}$. Evidentemente, con ello y de manera indirecta se le está confiando la puesta en práctica y supervisión de los sufragios encargados. Pues, además, las fundaciones de capellanías se sustentaban sobre la dotación de una prebenda, de un beneficio eclesiástico a favor de un individuo, religioso, que quedará adscrito a un determinado altar para celebrar misas por el bien del alma de su patrocinador.

Quizás muchos de ellos jugaron un papel relevante desde el punto de vista espiritual en vida del testador, como es el caso de los confesores. Su presencia es bastante extraordinaria entre los testamentos navarros consultados, aunque quizás el ejemplo más significativo sea el del señor de Novar, Juan de Sarría, vecino de Puente la Reina, quien además de encargar libras de óleo con las que mantener encendidas todas las lámparas repartidas por el interior de la iglesia de Santiago, donde recibirá sepultura, entregará dos florines de moneda a Miguel de Egüés, abad de Echarren y Guirguillano, su confesor por tal que mi anima aya encomienda ${ }^{317}$.

Por último, cabe mencionar otra modalidad de conmemoración religiosa, la convivio defunctorum, de la que ya se ha hablado, que unía a la misa una refección

telruiz, 1479 , c. 11, f. $11 \mathrm{r} .-12 \mathrm{v}$. (testamento de Catalina de Monreal) y f. 21r. (testamento de Dominga de Añón) así como otros 25 testamentos tudelanos.

314 ARICETA Esnaola, Lucas O.F.M.: «Los franciscanos en Tudela» en Cantabria Franciscana (San Sebastián) 15142 (1984), pp. 101-153. La tradición dice que la fundación franciscana de Tudela procede de dos frailes compañeros de San Francisco de Asís en su peregrinación a Santiago. Probablemente la primera fundación data de 1220 aunque hacia 1240 ó 1250, los frailes se trasladaron al convento de Griseras, en un solar donado por la familia Veraiz. Y con Carlos III en 1369 se trasladó a los frailes al interior de la ciudad. Entre 1430 y 1440, fray Pedro de Veraiz, franciscano natural de Tudela, arzobispo de Tiro y confesor de la reina Blanca, construyó a sus expensas la iglesia de San Francisco de Tudela, y también el hospital de Santiago para que se encargara especialmente de los religiosos del convento.

${ }^{315}$ AGN, Protocolos Notariales, Tudela, Juan de Frías, s.d., fajo 1468-1500, f. 102r.-102v. Se conserva un testamento posterior fechado el 21 de julio de 1479 así como el abonimiento de testamento el 9 de octubre de 1497. Son aún pocos los testamentos tudelanos que indiquen la presencia específica de franciscanos en los sufragios por los difuntos, en concreto dos más: Mateo Pérez de Miranda y Gracia Pérez de Agreda (Pedro de Latorre, 1492, c. 14) y Miguel de Falces y María Gracia (Martín Garceiz Don Costal, 1383, f. 202-205). A pesar de que un total de 84 testadores disponen ser enterrados en el convento franciscano de Tudela.

316 AGN, Protocolos Notariales, Salinas de Oro, Juan Miguel de Salinas, 1478, c. 1, n. 129.

317 AGN, Protocolos Notariales, Puente la Reina, Martín Brun, 1502, c. 1, n. 2. 
extraordinaria en memoria del difunto para conservar vivo su recuerdo y asegurar las oraciones. Este convite podía servirse ya fuese el día del fallecimiento o el del entierro, o bien el del aniversario u otra fecha fijada. En él participaban los clérigos que fuesen al entierro o a honrar el cuerpo, así como otros acompañantes laicos, familiares y vecinos entre los que destacarían los compañeros cofrades del testador. Los componentes alimenticios de este banquete se limitaban a pan, vino, carne o pescado, según el día, es decir respetando la vigilia ${ }^{318}$.

\section{La limosna}

En segundo lugar, las limosnas y las obras pías constituían un medio muy adecuado para asegurarse el favor divino, es decir el perdón de los pecados y la salvación eterna. En este caso la variedad es la nota general pero todas ellas están fundadas sobre el precepto de la caridad. Así entre las obras pías que aparecen en los testamentos nos encontramos la asistencia a pobres, la redención de cautivos, la dotación a muchachas casaderas y la financiación de hospitales ${ }^{319}$.

Hasta el siglo XII la pobreza era considerada un castigo divino y la riqueza como una bendición de Dios. Sin embargo, bajo la influencia del ideal apostólico y de los movimientos evangélicos se opera un cambio en la siguiente centuria. Y los laicos, sensibilizados por los predicadores que hablan de la pobreza de Jesucristo y de los apóstoles, comienzan a interesarse por los indigentes. Los hospitales se multiplican, se fundan las ordenes caritativas, la limosna viene a ser más frecuente pues se trata de socorrer a las víctimas de la injusticia como los necesitados, los leprosos y los enfermos. El pobre viene a ser ahora el representante de Cristo y comparte con Él en cierto sentido su función salvífica. Así la limosna viene a ser doblemente eficaz, porque permite adquirir los méritos para la salvación y también beneficiarse de las oraciones de los pobres, intercesores privilegiados por estar próximos a Cristo ${ }^{320}$.

Algunos de los testamentos navarros reflejan ya esta idea, es el caso de Juan Goyerhe quien hacia 1500 deja a cuarenta pobres dos florines de moneda a cada uno para que rueguen a Dios por su alma ${ }^{321}$. O el de los marqueses de Ágreda que dejan alguna ropa de cama al hospital de Ablitas para que los pobres recen por ellos 322 .

Para las limosnas se puede hablar de una extrema parcelación o fragmentación de los legados que parecen ser dictados al detalle. De manera que hospitales, iglesias, pobres, cautivos y cofradías se verán beneficiados con entregas de

\footnotetext{
318 Cantera Montenegro, M.: «Religiosidad en la Rioja bajomedieval», p. 129.

319 JULIÁ ViÑAMATA, Jose Ramón: «Las actitudes mentales de los barceloneses del primer tercio del siglo XIV» en Anuario de Estudios Medievales (Barcelona) 20 (1990), p. 28.

320 MARANDer, M.-C.: Le souci de l'au-delà, p. 453.

321 AGN, Protocolos Notariales, Santesteban, [1500], c. 1.

322 AGN, Protocolos Notariales, Tudela, Juan Martínez Cavero, 1505, c. 4, f. 168v.-171r.
} 
bienes materiales o bien de sumas de dinero. Así pues, en primer lugar podemos distinguir entre los legados destinados a pobres y a hospitales. En segundo término aquellos destinados a jóvenes para casarse, o bien a la financiación de obras públicas, todos ellos expresión manifiesta de una relación con la vecindad y la comunidad.

Estas donaciones no siempre eran en dinero o trigo, la práctica más frecuente, sino que en gran parte de casos se precisaban determinados bienes materiales de inmediata utilidad dejados a individuos e instituciones más necesitadas. Así María Miguel de Atondo, viuda de Miguel Izco y vecina de Vidaurreta, lega en su testamento de 1499 dos cuxtias de lana para en ayuda de las camas que los pobres de Dios se acujen y alberguen en el dicho hospital, se refiere al hospital de la cofradía de Belascoáin. Esto mismo ordena Teresa López de Salinas de Oro pero esta vez para la cofradía de Salinas ${ }^{323}$. También Toda, viuda de García de Subiza y vecina de Tudela deja al Hospital de Roncesvalles un lecho de ropa para los pobres ${ }^{324}$. Linzuelos ${ }^{325}$, colchas ${ }^{326}$ y todo tipo de ropa de cama eran destinados a estos hospitales que actuaban como centros de asistencia y acogida de los más desamparados. Otro tipo de práctica común, tal como lo atestiguan algunos testamentos tudelanos, un total de 8 , era vestir a un determinado número de pobres que en algunos casos han formado parte del cortejo fúnebre portando cirios y antorchas $^{327}$. Estas mandas pías de carácter asistencial son expresión de una caridad bien vivida y sentida, y entre este tipo de limosnas deben ser mencionadas las destinadas a la redención de cautivos cristianos en territorio musulmán. Así Juana de Izurzu, viuda de Juan Gómez, que en 1478 dispone que se venda alguna de su ropa y que el dinero se destine a la redención de cautivos ${ }^{328}$. Junto a este documento otros 15 testamentos recogen esta práctica piadosa a la que se destinaban tanto sumas de dinero, aceite o robos de trigo, en función de la condición social del testador.

Como hemos podido advertir, los hospitales eran centros receptores de muchas de estas mandas piadosas y entre ellos destacan el de Roncesvalles, Santa María de Pamplona, el Hospital de Santiago en Puente la Reina, el Hospital de Lesaca y el de Salinas de Oro, pero sobre todo la mayor profusión de estas fundaciones asistenciales la encontramos en Tudela. Aquí podemos identificar a través

323 AGN, Protocolos Notariales, Salinas de Oro, Juan Miguel de Salinas, 1499, c. 2, s. c y 1481 , c. 1, n. 171 .

${ }^{324}$ AGN, Protocolos Notariales, Tudela, Martín García don Costal, 1383, f. 263-264.

325 AGN, Protocolos Notariales, Salinas de Oro, Juan Miguel de Salinas, 1494, c. 2, n. 23; 1472 , c. 1, n. 35 bis; 1511 , c. 4 .

326 AGN, Protocolos Notariales, Salinas de Oro, Juan Miguel de Salinas, 1509, c. 3.

327 Es el caso del médico tudelano Francisco de Lenoz, AGN, Protocolos Notariales, Tudela, Juan Martínez Cavero, 1508, c. 5, f. 119. Junto a otros siete ejemplos.

328 AGN, Protocolos Notariales, Salinas de Oro, Juan Miguel de Salinas, 1478, c. 1, n. 129. Otros 15 testamentos recogen esta práctica piadosa a la que se destinaban tanto sumas de dinero, aceite o robos de trigo, en función de la condición social del testador.

Hispania, LXV/1, núm. 219 (2005) 155-226 
de los testamentos el hospital de Santa María de Tudela, que recibe el mayor número de limosnas, el hospital de Santiago, en segundo lugar, y en tercer lugar el hospital de la cofradía de Ballesteros y el de Santa María de Gracia.

Pero junto a los hospitales, los centros religiosos, es decir las iglesias, parroquias y santuarios, se convierten en un obligado punto de recepción de esas piadosas dádivas. En el medio rural navarro parece ser una práctica bastante generalizada la entrega de la oblada. Son un total de 233 testamentos los que mencionan la oblación y candela que se debía dar a la iglesia donde se recibía sepultura. Esta ofrenda consistía en cierta cantidad de pan o de grano - la oblada - , de vino la oblación - y de cera - candela - para las celebraciones y solía hacerse a diario durante un año o dos tras la muerte del testador, o a veces incluso de algún familiar. En los testamentos se fijaba la cuantía y la persona encargada de realizar esta ofrenda, siempre una mujer y por lo general del ámbito familiar. La oblada se solía llevar ante la sepultura del testador o ante el altar donde se celebraban las exequias, pero a veces se establecía la entrega en otra iglesia ${ }^{329}$.

Generalmente, la parroquia a la que estaba vinculado el testador en función de su vecindad es la primera destinataria de las limosnas. De modo que en muchas ocasiones dejará como ofrenda los cirios y antorchas que acompañaron al cadáver en el cortejo fúnebre, aunque también a veces eran repartidos entre diferentes iglesias de la zona. En otras destinará libras de óleo para cubrir esa necesidad tan básica y necesaria de los templos medievales como era la iluminación interior, tal y como demuestran 89 testamentos, en su gran mayoría de Salinas de Oro (74).

En relación a este último punto cabe señalar que junto a las referencias genéricas de aceite, aparecen casos bastante curiosos en los que se especifica a qué lámparas lo quiere destinar. Como Martín de Agorreta, vecino de Abárzuza, que deja a Santa María de Abárzuza 6 libras de olio para la lampeda del Corpus ${ }^{330}$. Y María de San Juan que dispone cuatro libras de óleo para la lámpara del altar mayor de la iglesia tudelana de San Salvador y otras cuatro para la lámpara de San Blas ${ }^{331}$. Lógicamente estas lámparas arderían junto a los altares dedicados a los distintos santos, por lo que se puede hablar de lámparas votivas, señales visibles de la devoción del fiel al santo a quien dirige su plegaria ${ }^{332}$.

Además de las tradicionales limosnas expresadas en robos de trigo y libras de aceite, muchas veces se detallarán sumas de dinero y la finalidad de las

329 Cantera Montenegro, M.: «Religiosidad en la Rioja bajomedieval», p. 130.

330 AGN, Protocolos Notariales, Salinas de Oro, Martín Martínez de Vidaurre, 1512, c. 9, n. 6.

331 AGN, Protocolos Notariales, Tudela, Juan de Frías, 1489, 2r.-3r. Un caso similar es el de Diego Valero quien manda aceite para las lámparas de San Antón y San Santilón, de donde es cofrade, así como para las de Santo Domingo y de San Babil, AGN, Protocolos Notariales, Tudela, Juan Martínez Cavero, 1490, c. 3, f. 36r.-37v.

332 GARCía DE LA BORBOlla, Ángeles: «La praesentia y la virtus: La imagen y la función del santo a partir de la hagiografía castellano-leonesa del siglo XIII» en Studia Silensia (Santo Domingo de Silos) 2002, p. 330. Esta práctica está documentada desde el siglo VI en el Occidente cristiano.

Hispania, LXV/1, núm. 219 (2005) 155-226 
mismas. Estas cantidades solían ser destinadas a la obra de la iglesia, por ejemplo para efectuar alguna mejora, como la que destina Graciana, viuda de Juan Peru, vecina de Maya para la reparación dela iglesia de Sant Miguel de cabo Urssua III florines de moneda ${ }^{333}$. O también para la realización de algún retablo que enriqueciese los desnudos muros de piedra ${ }^{334}$. De modo que el rector Juan de Guembe, manda en su testamento sepultarse en la iglesia de San Bartolomé delante del altar de Santa Bárbara, y al mismo tiempo lo descubrimos donando diez florines para la solución o licencia del altar de Santa Barbara, una actitud que permite apuntar una especial devoción hacia esta santa mártir ${ }^{335}$. De igual modo Pedro Lorenz, vecino de Tudela encarga sia fecho un retablo de las ymagines et figuras de seynnor Sant Pedro et de seynnor Sant Lorenz de XX florines el qual sera puesto sobre la dicha tomba abonor et reuerencia de los dichos santos por tal que ellos sean rogadores a nuestro seynnor Dios por mi anima ${ }^{336}$. En definitiva estas prácticas reflejan la idea de los santos como figuras mediadoras, pues sin duda, el santo es el interlocutor divino que acude al auxilio del fiel que lo invoca, así como el más inminente protector de los hombres ${ }^{337}$.

Este mismo sentimiento es el que parece inspirar a María de Clavería que manda ser enterrada en la capilla dedicada a San Sebastián en la catedral tudelana y que al mismo tiempo dejará un real de plata para la realización del retablo dedicado al santo mártir. Este mismo aparece sufragado durante los últimos años del siglo XV por otros vecinos de la ciudad ${ }^{338}$. Pero quizás el caso más destacado es el de Pascual de Magallón, donde vemos ejemplificado el eje linaje-santo-capilla, pues este canónigo tudelano, que pide ser enterrado en la capilla de San Eloy, donde está sepultada su madre y dice: he tenido intención y gana de rehedifficar la dicta capilla de SantEloy et dexar enella algun beneficio personal y perpetuo portal que Dios Nuestro Sennor enella fuesse mejor servido et las animas de mis sennores padre y madre y de mis deudos y parientes rescibiessen alla enla otra vida descanso y consolacion (...) por las diversidades delos tiempos y otras dificultades..., pero no pudo llevarlo a cabo y por ello deja la suma de 400 florines para las obras de esa capilla y para fazer un retablo

333 AGN, Protocolos Notariales, Santesteban, 1505, c. 1. Contamos con otros 19 ejemplos, de todos ellos la obra más destacada es la de la iglesia de San Francisco de Tudela.

${ }^{334}$ En este caso son 15 los ejemplos que dejan dinero para retablos como el de Santa María de Munárriz, Santa María de Irurre, San Martín, San Sebastián (capillas en Santa María de Tudela), retablo mayor de Santa María de Tudela o retablo de San Mateo en la iglesia de la Magdalena en Tudela, entre otros.

335 AGN, Protocolos Notariales, Salinas de Oro, Juan Miguel de Salinas, 1511, c. 4, s.c.

336 AGN, Protocolos Notariales, Tudela, 1493, c. 1.

337 GARCÍA. DE LA BORBOLLA, A.: «La praesentia y la virtus», p. 274.

338 AGN, Protocolos Notariales, Tudela, Sancho Ezquerro, 1485, f. 6r.-8r. Parecen ser para el mismo retablo de San Sebastián los tres florines dejados por Greva de Aibar, AGN, Protocolos Notariales, Tudela, Sancho Ezquerro, 1485, n. 29; los diez de Juan de Peñaranda, AGN, Protocolos Notariales, Tudela, Sancho Ezquerro, 1485, n. 48; los cinco groses de Catalina de Baztán, AGN, Protocolos Notariales, Tudela, Sancho Ezquerro, 1487; un florín de Juan de Castro, AGN, Protocolos Notariales, Tudela, Sancho Ezquerro, 1489, c. 12, f. 1r.-4v.

Hispania, LXV/1, núm. 219 (2005) 155-226 
para la dicta capilla enel qual pormemoria demis advenideros parientes mios sehayan de poner las armas que denuestro linaje tenemos ${ }^{339}$.

En relación con la mejora del ajuar de los templos hemos de señalar también las donaciones de piezas litúrgicas. Se trata en su mayoría de objetos relacionados con la Eucaristía dejados como legados piadosos y que evidencian una creciente devoción al Santísimo Sacramento. Entre ellos encontramos desde manteles ${ }^{340}$ o linzuelos ${ }^{341}$ para el altar, a paños destinados a la confección de casullas con su correspondiente manípulo y estola ${ }^{342}$. Así el capellán de Munárriz dejaba a su parroquia su propio manto para realizar esas vestiduras ${ }^{343}$; o Toda Martínez de Artieda, viuda de Juan de Falces y vecina de Tudela que deja una piel de paynno morada mya que yo be pora una casulla misa ${ }^{344}$.

Pero incluso a veces las donaciones son más ricas y sufragan la compra de vasos sagrados generalmente de plata, o bien aportan algún elemento de este precioso metal para su elaboración. Esto último es lo que hace Inés de Roncal, vecina de Tudela quien encarga la fabricación de dos cálices y sus patenas, uno para la catedral y otro para la iglesia de San Nicolás por las animas de mi padre i de mi madre $i$ por la mia, dejando para ello una taza de plata ${ }^{345}$. Cabe señalar que en estos casos siempre se especifica el valor del objeto por el peso del mismo, o bien por la calidad del metal ${ }^{346}$. Así Juan de Leytago, herrero y vecino de Tudela encarga que sus hijos den ala dicta iglesia de Santa Maria para empues dias del sobrevivient de nos ambos dos para servicio del santo sacrificio dela missa assaber es bun caliz de plata de balva de veynte florines de buen oro (...) es por tal que Nuestro Seynor Ihesu Christo et la Virgen Seynora Santa Maria su madre ayan merce delas nuestras animas ${ }^{347}$.

339 AGN, Protocolos Notariales, Tudela, Juan Martínez Cavero, 1508, c. 5, n. 1.

340 AGN, Protocolos Notariales, Tudela, Martín Don Costal, 1383, f. 253-255. Testamento de Dominga López quien además de dejar limosnas para la obra de San Francisco de Tudela y San Nicasio, manda que syan dados unos manteles para laltar de Santa María de Roncesvailles. Contamos con otros cinco ejemplos de testamentos de mujeres tudelanas que entre sus mandas dejan manteles para altares como el de Santa María la Mayor de Tudela o San Francisco.

341 AGN, Protocolos Notariales, Salinas de Oro, Martín Martínez de Vidaurre, 1500, c. 9, n. 4. Además contamos con otros 19 testamentos donde se dejan estos paños de lino listrados con listras de algodon para determinadas iglesias que se utilizarían como manteles de altar. En su gran mayoría son testamentos de Salinas de Oro, junto con Puente la Reina (1) y Santesteban (1).

${ }^{342}$ Un total de 7 testamentos nos hablan de este tipo de donaciones: tres en Tudela y cuatro en Salinas de Oro.

${ }_{343}$ AGN, Protocolos Notariales, Salinas de Oro, Juan Miguel de Salinas, 1502, c. 2. También deja su propia ropa Juan Miguel de Muez, AGN, Protocolos Notariales, Salinas de Oro, Juan Miguel de Salinas, 1504, c. 3.

${ }^{344}$ AGN, Protocolos Notariales, Tudela, Martín Don Costal, 1383, f. 207-209.

345 AGN, Protocolos Notariales, Tudela, Martín Don Costal, 1381, f. 59-60. Un total de 11 testamentos recogen esta práctica, todos tudelanos salvo el de García de Irurre, rector de Ariz.

346 Gutier García de Aguilar deja dos cintas de plata para hacer cálices de cuatro marcos de peso para el hospital de la Caridad de Santa María, por las almas de sus padres y la suya. AGN, Protocolos Notariales, Tudela, Martín Don Costal, 1382, f. 110-113.

347 AGN, Protocolos Notariales, Tudela, 1442, c. 1. 
No obstante, no debe olvidarse la finalidad de estas generosas donaciones, es decir la intercesión y mediación divina a la hora de ese juicio particular al que se somete el alma del difunto habiendo intentado reparar en esta vida todas sus ofensas y pecados. Aunque a veces se trata de "permutas", es decir, una ofrenda que supla un voto prometido pero no cumplido. Como el caso del notario Pedro de Lorenz de Tudela quien estando enfermo deja medio marco de plata, por descargo de mi conciencia por razon del voto que yo prometi yr alla, para una patena al no haber podido ir en romería a la iglesia de Santa María de Guadalupe tal y como había prometido ${ }^{348}$.

Finalmente, entre este tipo de legados «litúrgicos» cabe destacar el testamento de Romea Jiménez, viuda en segundas nupcias y vecina de Tudela, quien aunque manda enterrarse en la capilla de San Eloy de la catedral tudelana junto a su primer marido, favorece de manera destacada a la iglesia de San Juan en Cintruénigo, donde estaban enterrados sus padres y quizás fuera su lugar de origen. De modo que manda dar un arnes de altar qomplido así como tres savanas o manteles un caliz dargent de un marco corporales misal un vestiment qomplido de lienzo mas ampoillas destaynno para servitio del divinal oficio. En suma provee de todo lo necesario para la celebración eucarística en este templo ${ }^{349}$.

En relación a estas limosnas destinadas a centros religiosos quizás lo sorprendente sea comprobar la amplitud y extensión de las mismas hacia las iglesias circundantes, en primer término siempre la sede catedralicia para los núcleos urbanos y, en segundo lugar, a las parroquias vecinas. Evidentemente, en cada testamento suelen aparecer legados a la propia parroquia lo cual indica una noción de comunidad eclesial, pero también, y en marcado contraste con el área rural navarra, en el caso tudelano, otras parroquias reciben incluso más legados que la propia. Entre estas últimas destacan el convento franciscano, San Salvador, Santa María Magdalena, Santa María la Mayor, San Miguel, San Pedro, e incluso, a veces, tanto todas las iglesias de la villa como las situadas extramuros. Sin embargo, para Tudela se puede observar una clara tendencia a disminuir el número de este tipo de limosnas y en cambio se puntualiza y se hace mayor énfasis en el encargo de misas según los esquemas ya descritos.

No podemos terminar sin hacer referencia a esos centros religiosos más paradigmáticos en el solar navarro y que aparecen con frecuencia repetidos en numerosos testamentos, sobre todo en el área de Salinas de Oro. Estos santuarios son la catedral de Pamplona, Santa María de Roncesvalles, San Miguel Excelsis y Santa María de Ujué. Entre estas ofrendas, en trigo, aceite o mone$\mathrm{da}$, que aparecen de manera continuada entre los vecinos de Salinas de Oro, la más generalizada será la entrega de cinco sueldos a cada una de las iglesias, o bien dos o tres robos de trigo, en remisión de sus pecados, de manera que estas ofrendas tienen una carácter expiatorio.

348 AGN, Protocolos Notariales, Tudela, 1439, c. 1.

${ }^{349}$ AGN, Protocolos Notariales, Tudela, Martín Don Costal, 1383, f. 192-196.

Hispania, LXV/1, núm. 219 (2005) 155-226 
En conclusión, podemos señalar que el comportamiento que se viene dibujando en relación a las mandas pías tiende a que las limosnas decrezcan en favor de las misas que en el caso de los adinerados se traduce en las fundación de capellanías y misas perpetuas ${ }^{350}$. Por tanto, la actitud hacia la muerte toma un carácter más espiritual y pietista pues se da mayor énfasis a la celebración del misterio eucarístico, perfecta oblación de Cristo al Padre, que supera en infinitud las pequeñas ofrendas materiales que se venían haciendo hasta ahora. Todo ello contribuirá a reforzar la piedad eucarística entre los fieles que encargan estos sufragios para entrar libres de todo pecado en la Gloria del Paraíso.

\section{Valoración y propuestas finales}

Quizá la muerte es simplemente un instante. Pero a pesar de su carácter efímero, motiva un sistema de relaciones atemporales, complejas y trascendentes que se establecen entre el mundo terrenal y el mas allá.

Sin duda, los testamentos reflejan una clara solidaridad entre vivos y muertos. La intercesión por los difuntos es la ocasión de hacer efectiva la comunión de todos los cristianos. Y este intercambio entre la iglesia militante, purgante y triunfante, es una de las características de la sociedad medieval, fundada sobre la protección recíproca de los residentes de aquí y los del más allá.

Además, estas fuentes documentales permiten el estudio de las relaciones del individuo con la comunidad. De manera que el propio análisis de las oraciones por los muertos demuestra la dimensión comunitaria de todas las fundaciones cara a mantener su memoria ritualizada. Todos estos recursos de intercesión, desde el lugar de sepultura, las misas y oraciones por los difuntos, a la citación de sus confesores, influyen directamente tanto para resaltar su posición a la vista de la comunidad y de las instituciones, como para revelar la conciencia que ellos tienen de sí mismos y de sus relaciones con Dios y con el mas allá.

Pero también el testamento es el medio por el que el fiel asegura el futuro de su alma. El propio documento en sí es un deseo de arreglar lo terreno para procurar lo eterno, son dos mundos que no se presentan distantes o ajenos sino en perfecta relación en el espíritu del hombre medieval.

Según se desprende de la documentación de protocolos conservada y consultada, la práctica notarial en Navarra ya estaría configurada desde inicios del siglo XIV, a pesar de que sólo existan testimonios desde finales del XIV, que arrancan del cuaderno de escrituras del notario tudelano Martín don Costal. Un situación similar puede recogerse para Calatayud, cuyas series de protocolos comienzan en 1398 o Zaragoza, donde se conservan testimonios datados desde 1316. Sin embargo, otros textos indican que la actividad notarial ya estaba configurada en la ciudad ribera desde el primer tercio del siglo XIV, pues el fuero de Tudela de

350 MARTíneZ. GIL, F.: La muerte vivida, p. 126. 
1330 ya introducía normativas sobre la custodia de los registros notariales una vez que el escribano muriera. De todos modos, a pesar de la conservación de series parciales de protocolos bajomedievales para diversas zonas del reino como los valles de Baztán en el norte, de Salinas de Oro en Tierra Estella al oeste, y en el sur la ciudad de Tudela y su comarca, las series más completas y continuadas de documentación notarial datan del siglo XVI y aumentan de forma creciente para las centurias siguientes, al igual que ocurría con Castilla.

La práctica notarial demuestra el interés de los hombres navarros por redactar su testamento como un medio por el que ordenar sus asuntos materiales y espirituales. Constituye de tal modo, el testimonio vital del propio disponente. El notario, en este acto jurídico, actúa como un mediador legal que se encarga de poner por escrito y redactar de forma clara y concisa la voluntad e intenciones del testador. Los disponentes, al igual que sus coetáneos europeos, muestran una doble preocupación. En primer lugar, su deseo de elevación del alma a la Gloria divina para lo cual se encomienda a los santos y santas que componen la corte celestial, principalmente. En segundo lugar, su necesidad de mostrar la posesión de la plenitud de sus facultades mentales para así asegurar el reparto patrimonial de sus bienes materiales, y la plasmación jurídica de sus anhelos espirituales a través de la enumeración escrita de mandas piadosas a determinadas personas e instituciones religiosas y benéficas.

Una elevada proporción de testadores recurre a la redacción de testamento en un momento de enfermedad, estado que en el pensamiento medieval se asociaba al pecado. De ahí la doctrina eclesiástica y médica que aconsejaba la puesta por escrito de las últimas voluntades y la necesidad de recibir confesión y comunión, como principales vías de combate espiritual contra la enfermedad y en los estertores de la vida. Todo ello fue conformando un ritual de buena muerte cristiana a la que la comunidad de fieles debían someterse siempre que las circunstancias de la vida lo permitieran. Pero ello no era óbice para que el corpus médico, siguiendo estos postulados, tuviera una base especulativa y empírica tomando como método la experiencia y la razón. Aquel se refleja en algunos documentos que muestran cómo se combinaron los lenguajes médico y teológico, de cuya conjunción surgió la identificación de Cristo como médicosanador. La aplicación de los sacramentos purgaría de este modo los humores del diablo y los pecados humanos en los momentos finales de la existencia terrena y prepararía a los hombres en su paso al Más Allá.

Respecto a los rituales funerarios, debe indicarse que en la Baja Edad Media adquieren un sentido específico. En ellos no sólo se manifiesta la voluntad individual de cada testador, sino que también sus disposiciones son la expresión de una mentalidad colectiva de la comunidad a la que pertenece. De tal manera, el ritual se reviste en esta época de un tono social y público, en el que el protagonista es el muerto, pero otros personajes secundarios intervienen en las ceremonias, acompañando al difunto en su viaje a la otra Vida, proporcionando a este acto final una gran trascendencia. Así pues, una vez que se había producido el óbito, los testadores navarros celebran una serie de prácticas y ritos que guardan una 
gran semejanza con las ceremonias funerarias que pueden observarse para otros territorios hispánicos y europeos coetáneos, a pesar de contar con algunas particularidades locales, como se verá en la siguiente exposición.

En primer lugar se producía el aseo del cadáver, que venía indicado por algunos testamentos y documentos de gastos funerarios. Pero sobre todo, son más frecuentes las referencias al empleo de sudario, siendo predominante la elección del hábito de alguna orden mendicante, destacando la de los franciscanos. Estas peticiones son propias de la ciudad de Tudela frente a las áreas rurales, donde no se suele especificar cuál sería el tipo de mortaja que encargarían los difuntos, muy posiblemente, porque estaría más extendido el uso de lienzos de algodón y lino. En cuanto al empleo de ataúd, todos los datos obtenidos indican que sólo unos pocos testadores de la localidad de Puente la Reina eligen ser enterrados con él, en el interior de iglesia y parecen pertenecer a sectores acomodados de la villa. Así pues, esta práctica contrastaría con la realidad de la Daroca coetánea, donde a partir de la segunda mitad del siglo se generalizó el uso de féretro.

En segundo lugar, se procedía a la exposición y velatorio del cadáver, práctica que estaba más difundida en los núcleos rurales y muy posiblemente unida al sentido de vinculación a una comunidad más acentuado en éstos. En los pueblos navarros, especialmente en la comarca de Salinas de Oro, sería efectuado por los familiares, vecinos y hermanos cofrades del fallecido, así como clérigos del valle invitados para la ocasión.

Sigue a continuación el cortejo que conduciría al difunto a la iglesia, donde se realizaría el funeral de cuerpo presente, y posteriormente hasta su sepultura. Esta procesión de acompañamiento estaría compuesta de diferente forma según se diese en área rural o urbana. Mientras que en la urbe tudelana se hace mención expresa de grandes cortejos de pobres que eran vestidos a costa del difunto y que solían estar precedidos por una o varias cruces parroquiales, en el ámbito rural sólo se citan como integrantes del mismo a cofrades, familiares y amigos y a algunos religiosos y pobres. Todos ellos no sólo acompañarían al difunto en su último acto social, sino que también tendrían el encargo de rezar por su alma. Como compensación participarían posteriormente en un banquete que, sin embargo, se vio sometido a una rígida regulación por parte de las más altas instancias del reino. En algunas zonas rurales, principalmente en el valle de Salinas de Oro, se presentan, según indica la mayor parte de los testamentos, dos convites claramente diferenciados. En primer lugar, la colación, una ligera refección que tendría lugar en la plaza o ante la iglesia, a la que serían invitados todos los que habrían acudido al entierro. Y en segundo lugar, un banquete propiamente dicho al que asistirían los familiares más cercanos y religiosos del valle y al que ocacionalmente se podrían sumar pobres y compañeros cofrades.

Esta misma costumbre de la colación puede observarse en otras zonas peninsulares como La Rioja, Galicia o Castilla, así como en regiones francesas, como Aviñón. Sin embargo, el territorio aragonés, que sugiere comportamien- 
tos tan similares en otros aspectos funerarios, no registra esta costumbre. Frente a ello, en la ciudad de Tudela el banquete adquiere un sentido diferente, ya que no se le da la importancia de las áreas rurales. Los testadores que organizan una comida como las descritas son escasos, y más bien se inclinan por pitanzas a celebrar en establecimientos eclesiásticos de la villa, ofrecidas de modo excepcional a pobres y hermanos cofrades.

Finalmente, y en cuanto al cortejo, cabe indicar que los hombres navarros también se preocuparon por disponer una procesión de luces como modo de acompañamiento de sus cuerpos. La luz, sinónimo de Cristo Redentor, se simboliza a través de diferentes tipos de luminarias que los disponentes encargan con gran detalle describiendo las cantidades y pesos que deberían tener. Predominaban las antorchas frente a los cirios, demandados principalmente por las clases más acomodadas y por religiosos. Y se complementaban con candela menuda, que potenciaba la luminosidad del cortejo de una manera más asequible. Todas estas luminarias serían entregadas, en los núcleos rurales, a parroquias y ermitas designadas por el difunto en su testamento.

Por otro lado, sobre la sepultura, cabe señalar que en Navarra predomina durante estos siglos XIV a XVI la inhumación en cementerio, fundamentalmente en las áreas rurales, al igual que se registra en la comarca circundante a Calatayud para las mismas fechas. Como contraposición, los porcentajes más elevados de enterramiento en el interior del templo se dan en la ciudad de Tudela. Es significativo destacar además que en las aldeas incluso personajes notables de la pequeña nobleza local se hacen enterrar en sus cementerios parroquiales. Por el contrario, la urbe tudelana, gentes de toda condición social, desde miembros de la alta nobleza y burguesía a pequeños artesanos, eligen inhumación en interiores de templos, así como en claustros. Además, mientras que la práctica totalidad de los habitantes de los pueblos eligen sus parroquias como ubicación de sus sepulturas, en Tudela, sólo un tercio de sus habitantes hacen lo propio. La mayor diversidad de establecimientos religiosos, así como la influencia de las órdenes mendicantes y los enterramientos de familiares en otras iglesias distintas de la parroquia de los fallecidos, fueron factores determinantes para que se produjese tal fenómeno.

Las capillas constituyen, junto con el coro y el presbiterio, los lugares más destacados de inhumación en el interior del templo. Al igual que ocurría en otras regiones del occidente medieval, la construcción y posesión de sepulturas monumentales, ubicadas en grandes capillas financiadas por linajes relevantes, constituyeron un elemento de prestigio y de poder social que magnificaba las personas y apellidos de determinadas familias. Por ello, quienes tuvieron posibilidades económicas, edificaron o acondicionaron espacios específicos donde ubicar sus panteones gentilicios en los que se agrupaban diferentes generaciones de una misma parentela. Esta manifestación de reagrupamiento no sólo fue propia de las clases con mayor poder socioeconómico, sino que también fue practicada a menor escala y en función de su potencial, por gentes de toda con- 
dición. Como en la mayor parte de Europa, las personas con quienes se desea reposar más frecuentemente son el padre y la madre, tanto por separado como conjuntamente, así como el esposo, en el caso de la mayoría de las viudas, o la esposa. También los hijos, hermanos, abuelos y otros parientes son elegidos como compañeros de sepultura. Referente a la tipología de las tumbas, las más comunes son las fosas, ubicadas tanto en cementerio, como en claustro y en el interior de la iglesia. También son citados algunos ejemplos de sepulcros monumentales. Pero destaca, por ser una peculiaridad de esta zona, el carnero o carnario, un tipo de sepulcro eminentemente familiar que cumpliría una doble función como sepultura y osario.

Para terminar con estas conclusiones, y con respecto a la espiritualidad de los navarros bajomedievales, debe decirse que ponen especial celo en detallar los sufragios y las disposiciones piadosas que deberán efectuarse una vez que hubiera fallecido. En primer lugar debe hablarse de los sufragios, destacando dos tendencias para Navarra, al igual que otros autores indican para diversas regiones francesas. Por un lado, existen unos sufragios que toman su raíz en la repetición y la cantidad de misas encargadas, tal es así en las novenas, trentenarios y cabos de año. Por otro, se dan unos oficios que tienen su fundamento en la perpetuidad, tales como las capellanías y aniversarios. Pese a ello, no puede concluirse que exista ninguna tendencia al incremento cuantitativo de encargos de misas. Por el contrario, son muy frecuentes los ciclos de oficios religiosos que se pueden observar en otras regiones peninsulares y occidentales, con los trentenarios de San Amador, típicos de localidades de carácter más urbano, como Tudela o Puente la Reina, así como ciclos de misas de Réquiem, o misas de votivas en honor de la Virgen.

La acumulación de oficios en los días inmediatamente posteriores a la muerte del testador es muy habitual en las áreas rurales, donde se encargan misas de tercer día, novenas, cabos de novena y trentenas cerradas. Por contraposición, en Tudela, más cosmopolita y con una mayor concentración de riqueza, es práctica ordinaria el encargo de misas de Réquiem, a celebrar tras el fallecimiento de forma repetitiva durante un determinado período de tiempo (treinta días seguidos, dos o tres veces al año o anualmente) o a perpetuidad. Todos estos encargos no sólo beneficiarían al alma del testador, sino que su acción salvífica se extendería a otros familiares fallecidos y a otras personas cuyas almas les habían sido encomendadas y a familiares que por diversas circunstancias habrían muerto sin auxilios espirituales. Igualmente destacan las fundaciones de aniversarios y capellanías, que garantizarían el sufragio eterno por un alma. De entre los aniversarios, debe citarse una tipología muy específica que se encuentra en Tudela a fines del siglo XV denominado «aniversario de nobilium et magnatum et campana Maria», cuya liturgia nos es desconocida. Las capellanías, sin embargo, consistirían en misas diarias a celebrar a perpetuidad por las almas de los difuntos testadores que las habían instituido y por las de sus familiares. La gran mayoría de quienes las encargaban establecían que se celebrasen en un al- 
tar, que podía ser el principal de la iglesia o uno privado situado en su capilla familiar donde se hacían enterrar. El encargo de capellanías es una práctica muy frecuente entre clérigos y personajes de la nobleza y alta burguesía, pero también entre todos los testadores, ya que su popularidad residía en la flexibilidad de la misma; así pues, quienes no tuviesen posiblidades de solicitar la celebración de una entera, podían demandar media capellanía, lo que es muy habitual en el área rural. Junto con estos oficios, muchos son los testadores que encargan la celebración de responsos sobre su sepultura, una vez que hubiese acabado la misa, acompañados de la bendición de su sepultura con agua bendita.

En segundo término, hay que subrayar que las limosnas y obras pías eran el medio más utilizado por los testadores para obtener el perdón divino, práctica que fue aconsejada no sólo por las autoridades eclesiásticas, sino también por los predicadores como vía de salvación. Los pobres fueron los principales beneficiarios de estas limosnas, dado que eran considerados como los representantes simbólicos de Cristo en la tierra y compartían con Él, en cierta medida, su función salvífica, al mismo tiempo que actuarían como mediadores privilegiados ante Dios, con lo que se les encargaban numerosas oraciones por las almas de los testadores. Igualmente, otras instituciones de carácter asistencial y caritativo como hospitales y asilos recogen donaciones a través de la vía testamentaria, tanto monetarias como en especie (ganado, cereales) o de ajuares (ropas, juegos de cama). A pesar de que existen numerosos centros de este tipo en las diferentes localidades y valles del reino, destaca de entre los documentos de protocolos, la ciudad de Tudela por ser éste el núcleo donde aparecen concentrados en mayor número. Junto con ellos, parroquias, santuarios y otras iglesias, son beneficiados con diferentes mandas piadosas. De entre ellas, destaca la oblada u ofrenda de pan (o grano), y cera (candela) a la que, en algunos lugares, se sumaba el vino. Esta oblada, típica del medio rural, era ofrecida durante un año por el alma del fallecido sobre su tumba o ante el altar parroquial, como también se documenta para La Rioja. Conjuntamente con estos productos también se efectúan donaciones de velas, robos de cereal (trigo y cebada) y libras de aceite. Todas estas ofrendas servirían para el mantenimiento diario del culto y la subsistencia del clero local. Pero algunos testadores van más allá e incluso, costean obras de edificios religiosos, tales como conventos o parroquias, patrocinan la compra o fabricación de objetos litúrgicos como retablos, cálices y patenas o donan linzuelos y ropas para la confección de vestimentas litúrgicas y manteles de altar.

En cuanto a las áreas rurales, preferentemente en Salinas de Oro, destaca un fenómeno que no se aprecia en Tudela, la donación de ofrendas de dinero, trigo o aceite en cantidades estipuladas (cinco sueldos, dos o tres robos de aceite; por ejemplo) a los principales santuarios del reino tales como Santa María de Pamplona, Roncesvalles, San Miguel de Excelsis y Santa María de Ujué. Por el contrario, los testadores tudelanos centran su atención en las principales iglesias y conventos de la ciudad, además de las ermitas ubicadas tanto en el interior del recinto urbano como extramuros. Por otro lado destacan también 
las dádivas a los confesores, la dotación de muchachas casaderas, las limosnas a vecinos y familiares sin fortuna, la liberación de cautivos y el pago de peregrinaciones como los recursos para obtener méritos de cara a la salvación, a través del ejercicio de la caridad.

En definitiva y por todo lo expuesto en esta investigación focalizada en el territorio navarro, no cabe duda de que los Protocolos Notariales constituyen una fuente indiscutible para conocer y adentrarse en el mundo mental medieval. En concreto, en sus creencias, actitudes y representaciones ante la muerte. No obstante, el método cuantitativo de análisis no es un fin en sí, sino que ha de simbolizar el riguroso estudio de una larga serie documental en el tiempo y en el espacio. La fecundidad espiritual de los textos se convertirá así en el eje que absorba y aglutine las convicciones y comportamientos de una sociedad capaz de dar respuesta religiosa a las más trascendentes preguntas y aspiraciones del hombre. 